\title{
Transformação do capital imobiliário e manutenção da estrutura fundiária: reproduzindo a segregação territorial
}

Tese apresentada ao Programa de Pós-Graduação da FAUUSP como parte dos requisitos para obtenção do título de Doutor em Arquitetura e Urbanismo

Área de Concentração: Planejamento Urbano e Regional Orientadora: Ermínia T. M. Maricato 
Autorizo a reprodução e divulgação total ou parcial desta tese de doutorado por qualquer meio, convencional ou eletrônico, para fins de estudo e pesquisa, desde que citada a fonte.

\section{E-mail da autora: patriciacezario.br@gmail.com}

FICHA CATALOGRÁFICA

Silva, Patrícia Cezario

S586t Transformação do capital imobiliário e manutenção da estrutura fundiária: reproduzindo a segregação territorial / Patrícia Cezario

Silva. -- São Paulo, 2015.

136 p.: il.

Tese (Doutorado - Área de Concentração: Planejamento Urbano e Regional) - FAUUSP.

Orientadora: Ermínia Maricato

1.Mercado imobiliário 2.Planejamento territorial 3.Planos diretores -

São Paulo (SP) 4.Politica habitacional 5.Segregação urbana I.Título

CDU 332.72 
Agradecimentos

Esta pesquisa de doutorado contou com o apoio de bolsa concedida pela Fundação Fulbright, que permitiu a estadia como pesquisadora visitante no Department of Urban Studies - DUSP do Massachusetts Institute of Technology - MIT, durante o ano acadêmico de 2012-2013. Também obtive apoio do Lincoln Institute of Land Policy, para participação de seminário de pesquisadores acadêmicos realizado em outubro de 2014 em Buenos Aires.

Em primeiro lugar, agradeço a objetividade e a generosidade com que Ermínia tratou a relação orientadora-orientanda, especialmente na etapa de redação final da tese. Agradeço a meus pais, Cleuza e Nilton, e a meu irmão, Pablo, pelo apoio de sempre. Agradeço a intensa interlocução e a companhia de Eduardo Jorge Canella.

A Jonathas Magalhães Pereira da Silva agradeço o estímulo desde a inscrição no processo seletivo, e também a atenta leitura da tese. A Marco Lagonegro agradeço as conversas recheadas de erudição. A Ana Clara Bellan agradeço o acompanhamento das questões de pesquisa e da vida ao longo do último ano. Agradeço às Professoras Klara Kaiser Mori e Yvonne Mautner, pela inspiração, apoio, gentileza e amizade. Agradeço à Professora Raquel Rolnik o interesse na pesquisa e perguntas certeiras.

Agradeço a Javier Tonatto a positividade em momentos delicados durante a pesquisa. Agradeço o acolhimento de Ana Beatriz Bersano na chegada e durante os dez meses em Boston, e a companhia dos colegas de bolsa da Fulbright, especialmente a de Gabriela Rembarz e Anush Hovakimyan. Aos professores Bish Sanyal, Phillip Thompson, Tunney Lee, Gabriella Carolini, Sara Williams and Lawrence Vale, do DUSP - MIT, agradeço as conversas e os trabalhos inspiradores. Agradeço a André Herzog pela oportunidade de me aprofundar nas condições em que se pratica urbanização e regularização de favelas em pelo menos onze países muito distintos entre si.
A Arlete Rodrigues agradeço imensamente a participação na banca de qualificação e as importantes contribuições para o encaminhamento da pesquisa. A Eduardo Nobre, além da participação na banca de qualificação, agradeço também o companheirismo durante o ano de desenvolvimento da pesquisa que realizamos no contexto do convênio entre Instituto de Pesquisa Econômica Aplicada - IPEA e Secretaria Municipal de Desenvolvimento Urbano - SMDU da Prefeitura do Município de São Paulo, que resultaram em grande parte da pesquisa empírica apresentada no Capítulo 4 desta tese. A Armando Palermo Funari, também colega na pesquisa SMDU-IPEA, agradeço a troca de ideias e a leitura atenta na reta final de redação da tese, apontando lacunas a serem preenchidas. Aos outros colegas na pesquisa SMDU-IPEA: Claudia Acosta, Ligia Pinheiro, Luis Martins Borges e Pedro Braumgratz de Paula, agradeço a companhia nas discussões sobre instrumentos urbanísticos potencialmente inovadores e as dificuldades para uma efetiva implementação. Agradeço aos funcionários da prefeitura com quem tive conversas importantes para o desenvolvimento desta pesquisa: Anna Kaiser Mori, Bruno Borges, Carolina Heldt, Edson Capitânio, Guilherme Minarelli, Jenny Zola, Letícia Sígolo, Marcelo Bernardini, Marcia Terlizzi, Pedro Rivaben de Sales, Rodrigo Tanaka, Taís Tsukumo, Tomás Wissenbach.

Agradeço os excelentes mapas que Edson Capitânio elaborou, fundamentais para construir a análise realizada no Capítulo 4 desta tese. Agradeço a Andras Petho pelas sugestões para o Abstract. Agradeço a Eduardo Campos pelo projeto gráfico e pela diagramação da tese. 
Deitou-se remendo de pano novo em vestido vel ho, vinho novo em odres velhos, sem que o vestido se rompesse nem o odre rebentasse. O fermento contido, a rasgadura evitada gerou uma civilização marcada pela veleidade, a fada que presidiu ao nascimento de certa personagem de Machado de Assis, claridade opaca, luz coada por um vidro fosco, figura vaga e transparente, trajada de névoas, toucada de reflexos, sem contornos, sombra que ambula entre as sombras, ser enão ser, ir e não ir, a indefinição de formas e da vontade criadora.

Raymundo Faoro 


\section{Resumo}

Sem o devido enfrentamento da questão do acesso à terra, a expansão da produção habitacional de mercado, mesmo que subsidiada, não é capaz de solucionar o problema da moradia nas cidades brasileiras. Pelo contrário, contribui para o agravamento de desigualdades socioterritoriais

Reformas estruturais das condições de financiamento e crédito foram implementadas a partir do final da década de 1990, amparando o boom imobiliário ocorrido nos anos de 2000. No entanto, por prescindir de transformação da estrutura fundiária, o salto da produção seguiu a lógica de segregação espacial entre ricos e pobres.

A partir do estudo empírico da produção imobiliária dos anos 2000 no município de São Paulo, verificamos que os esforços do poder público municipal em intervir em favor da democratização do acesso à terra acabam sendo desviados do seu foco principal.

No Plano Diretor aprovado em 2014, o município de São Paulo instituiu a Cota de Solidariedade. O instrumento previa, na proposta enviada inicialmente pelo poder executivo à Câmara dos Vereadores, a atuação direta sobre um dos principais entraves à produção habitacional de interesse social, que é a aquisição de terrenos bem localizados. No entanto, durante o processo de aprovação do Plano Diretor o instrumento foi sendo moldado de acordo com interesses de empreendedores imobiliários, num ajuste entre obrigação e conveniência.

Resulta disso que a Cota de Solidariedade configura mais uma tentativa de regulação do ordenamento territorial com instrumentos que não incidem nem reverberam na reestruturação fundiária. Ao invés de enfrentar, reproduz o padrão segregador de produção habitacional, e ao invés de minimizar, aprofunda as desigualdades sociais características das cidades brasileiras. habitacional, Segregação urbana.

\section{Abstract}

Without properly coping with the issue of access to land, the expansion of housing production, even subsidized, cannot solve the housing problem in Brazilian cities. On the contrary, it contributes to the deepening of socio-territorial inequalities.

Structural adjustments of financing and credit conditions have been implemented since the end of the 1990s, supporting the housing boom occurred in the 2000s. However, for waive transformation of the land structure, the leap in production followed the logic of spatial segregation between rich and poor.

Based on the empirical study of real estate production of the 2000s in the municipality of São Paulo, we find that the efforts of the municipal government to intervene in favor of land access democratization end up being deflected from their primary focus.

In the Master Plan approved in 2014, the city of São Paulo established the "Solidarity Quota". The instrument provided, in the proposal initially sent by the executive branch to the City Council, the direct action on one of the main barriers to housing production of social interest, which is to acquire well-located land. However, during the legislative process of the Master Plan, the instrument has been shaped by the interests of real estate developers, in a compromise between obligation and convenience.

The consequence is that the Solidarity Quota sets another attempt to regulate land use and occupation with instruments that do not affect nor reverberate in land restructuring. Instead of addressing the segregated pattern of housing production, enables its reproduction Instead of minimizing, it deepens social inequalities in Brazilian cities. 


\section{Lista de gráficos}

Gráfico 1 - Valor total financiado com recursos do SBPE entre 2002 e 2013 p. 24

Gráfico 2 - Número de unidades financiadas com recursos do SBPE entre 2002 e 2013 p. 24

Gráfico 3 - Etapas da produção habitacional pelo mercado privado p. 28

Gráfico 4 - Composição do valor de venda da Unidade Habitacional no Programa Minha Casa Minha Vida p. 30

Gráfico 5 - Empreendimentos residenciais lançados por ano no municipio de São Paulo de 2000 a 2010 p. 56

Gráfico 6 - Unidades habitacionais lançadas por ano de 2000 a 2010 p. 57

Gráfico 7 - Área de terrenos consumidos por ano na produção habitacional de 2000 a 2010 p. 57

Gráfico 8 - Empreendimentos com valor de venda até $\mathrm{R} \$ 190.000,00$ em relação ao total de empreendimentos residenciais lançados de 2000 a 2010 p. 59

Gráfico 9 - Modelo simplificado de origem e destinação de recursos do Fundo de Desenvolvimento Urbano - FUNDURB p. 98
Lista de imagens

Imagem 1 - Unidades habitacionais do Programa Minha Casa Minha Vida em Campinas p. 26

Imagem 2 - Empreendimento Minha Casa Minha Vida construído em terrenos remanescentes de conjuntos da COHAB-SP em Itaquera p. 32

Imagem 3 - Obras do monotrilho na Avenida Roberto Marinho, antiga Águas Espraiadas p. 44

Imagem 4 - Concentração de pessoas aguardando ônibus em Osasco, provavelmente na década de 1960 p. 49

Imagem 5 - $\quad$ Loteamento da Vila Matilde, em 1963 p. 50

Imagens 6 e 7 - Autoconstrução em terrenos oriundos de regularização fundiária em Taboão da Serra p. 5

Imagens 8 a 10 - Demolição de edifício de 8 pavimentos e stands de vendas de lançamentos ao longo do eixo do Elevado Costa e Silva p. 62, 63

Imagem 11 - Gleba Santa Etelvina, no início dos anos de 1980, em obras de terraplenagem para implantação de conjuntos habitacionais da COHAB-SP p. 75

Imagem 12 - Gleba Santa Etelvina, em 1983, obras de implantação de conjuntos habitacionais da COHAB-SP p. 75

Imagem 13 - Gleba Santa Etelvina, nos anos de 2000, várias gerações de conjuntos habitacionais da COHAB-SP p. 76

Imagens 14 a 17 - Empreendimento Faixa 1 - Rua Cachoeiro do Arrependido, na Cohab Raposo Tavares p. 83

Imagens 18 a 20 - Empreendimento MCMV Faixa 2 - Rua Leais Paulistanos, Ipiranga p. 84

Imagens 21 a 23 - Empreendimento Faixa 3 - Rua Milton Soares, Rio Pequeno p. 85

Imagens 24 a 26 - Empreendimento MCMV Faixa 2 na área central do município Rua Major Sertório, República p. 86 


\section{Lista de tabelas}

Tabela 1 - Déficit habitacional na Região Metropolitana de São Paulo por componente p. 26

Tabela 2 - Recursos destinados ao PMCMV por faixa de atendimento entre 2009 e 2012 p. 27

Tabela 3 - Unidades entregues pelo Programa Minha Casa Minha Vida entre 2009 e junho de 2013 p. 27

Tabela 4 - Empreendimentos e unidades habitacionais contratados pelo Programa Minha Casa Minha Vida entre 2009 e 2012 p. 59

Tabela 5 - Variação de área de terreno ocupada, área construída e número de lotes por tipologias de usos entre 2000 e 2013 no município de São Paulo p. 61

Tabela 6 - Área de terrenos vagos em 2000, 2013 e variação 2000-2013 p. 64

Tabela 7 - Área de terrenos ocupados por uso residencial vertical de baixo padrão em 2000, 2013 e variação $2000-2013$ p. 68 a 70

Tabela 8 - Terras adquiridas pela COHAB-SP no município de São Paulo entre 1965 e 1991 p. 76

Tabela 9 - Empreendimentos privados de interesse social e de mercado popular lançados de 2000 a 2010 no município de São Paulo p. 77, 78

Tabela 10 - Empreendimentos contratados pelo Programa Minha Casa Minha Vida entre 2009 e 2012 no município de São Paulo - Faixas 1, 2 e 3 p. 79, 80

Tabela 11 - Produção imobiliária com área útil maior que 20.000 m² entre 2000 e 2010 p. 99

Tabela 12 - Empreendimentos com área útil > 20.000 m² lançados entre 2000 e 2010 p. 101

Tabela 13 - Potencial de produção de HIS por aplicação da Cota de Solidariedade com base na produção imobiliária entre 2000 e 2010 - Opção 1 p. 104

Tabela 14 - Potencial de produção de HIS por aplicação da Cota de Solidariedade com base na produção imobiliária entre 2000 e 2010 - Opção 2 p. 109

Tabela 15 - Potencial de aquisição de terrenos e de produção de HIS por aplicação da Cota de Solidariedade com base na produção imobiliária entre 2000 e 2010 - Opção 3 p. 11

Tabela 16 - Potencial de aquisição de terrenos e de produção de HIS por aplicação da Cota de Solidariedade com base na produção imobiliária entre 2000 e 2010 - Opção 4 p. 116
Lista de mapas

Mapa 1 - Localização das favelas e loteamentos irregulares no município de São Paulo p. 32

Mapa 2 - Evolução da mancha urbana na área metropolitana de São Paulo $1881-2000$ p. 48

Mapa 3 - Ocupação por terrenos vagos entre 2000 e 2013 p. 67

Mapa 4 - Ocupação por uso residencial horizontal de baixo padrão entre 2000 e 2013 p. 71

Mapa 5 - Localização de empreendimentos de habitação de interesse socia produzidos entre 2000 e 2010 p. 73

Mapa 6 - Empreendimentos com área útil maior que $20.000 \mathrm{~m}^{2}$ lançados entre 2000 e 2010 p. 100

Mapa 7 - Domicílios com renda domiciliar maior que 20 salários mínimos no município de São Paulo p. 102

Mapa 8 - Distribuição do emprego formal no município de São Paulo p. 102

Mapa 9 - Potencial de localização da produção de HIS por aplicação da Cota de Solidariedade com base na produção imobiliária entre 2000 e 2010 - Opção 1 p. 104

Mapa 10 - Potencial de localização da produção de HIS - Opções 2 e 3 p. 107

Mapa 11 - Potencial de localização da produção de HIS - Opções 2 e 3 p. 108

Mapa 12 - Potencial de localização da produção de HIS - Opção 3 p. 112

Mapa 13 - Potencial de localização da produção de HIS - Opção 4 p. 115 
1.1 Condições de acesso à terra no contexto do boom imobiliário residencial

1.2 Reformas no sistema de financiamento como preparação para o boom imobiliário

p. 39 CAPÍTULO 2 Fundamentos históricos da propriedade da terra no Brasil

2.1 O padrão de ocupação da terra no Brasil: patrimonialismo e segregação socioterritorial

2.2 O padrão segregador da produção habitacional no município de São Paulo

SEGUNDA PARTE

p. 55 CAPÍTULO 3 Dinâmica territorial da produção imobiliária residencial no município de São Paulo na década de 2000

3.1 Produção imobiliária por categorias de uso

3.2 Padrões de localização da produção de habitação de interesse social e de mercado popular

p. 89 CAPÍTULO 4 Potencial da Cota de Solidariedade como instrumento de ampliação do acesso à terra para provisão de habitação de interesse social

4.1 O Plano Diretor Estratégico de São Paulo de 2014

4.2 O instrumento urbanístico Cota de Solidariedade

4.2.1 Potencial de produção de habitação de interesse social por meio da Cota de Solidariedade

4.2.2 Potencial de transformador minimizado

CONSIDERAÇÕES FINAIS

$p .123$ O potencial transformador da Cota de Solidariedade minimizado à conveniência do capital imobiliário

p.129 Referências Bibliográficas 
Introdução
As formas de acesso à terra são estruturadoras da questão habitacional. Os caminhos do enfrentamento de entraves ao acesso à terra para produção de habitação para as camadas mais pobres da população passa por reformas que abarcam os diversos aspectos que compõem a estrutura fundiária: o regime de propriedade da terra, as dinâmicas de distribuição ou concentração da propriedade, o sistema de registros de imóveis, a legislação e a prática do parcelamento e distribuição dos usos do solo, assim como a interação com os sistemas de proteção ambiental.

Sem uma reestruturação fundiária, a expansão da produção habitacional de mercado, ainda que subsidiada por meio de programas públicos, não dá conta de solucionar o problema habitacional nas cidades brasileiras.

O grande salto dado na produção imobiliária residencial no Brasil a partir de meados dos anos de 2000 foi viabilizado por reformas nos sistemas de crédito imobiliário, incremento na destinação de subsídios para a produção habitacional, e ainda por um aumento da renda das camadas médias da população. Esse crescimento abrangeu também a produção habitacional de interesse social e de mercado popular, especialmente a partir do início da operação do Programa Minha Casa Minha Vida ${ }^{1}$ - PMCMV, em 2009.

Apesar de ter o foco de seus objetivos apontado para o estímulo à produção e ao emprego por meio do financiamento do setor da construção civil, o PMCMV resultou em grande incremento da produção residencial para médias e baixas rendas, o que não acontecia em larga escala desde o encerramento da atuação do Banco Nacional de Habitação - BNH, em 1986. Entre 2009 e 2012, houve um incremento de 1,2 milhões de novas unidades produzidas por meio do PMCMV ao estoque residencial nacional. No entanto, somente $27,3 \%$ dessa produção foi destinada às camadas mais pobres da população, atendidas pela Faixa 1 do Programa (MCidades, 2013).

1. O Programa Minha Casa Minha Vida foi regulamentado por meio da Lei Federal no 11.977, de 07.07.2009 e resoluçōes posteriores. 
A ampliação da produção imobiliária residencial foi amparada por uma importante reforma no sistema de financiamento e oferta de crédito, que reforçou as garantias aos credores e viabilizou o grande aporte de recursos aplicados no salto da produção habitacional de interesse social e de mercado popular. As reformas no sistema de financiamento não foram acompanhadas de reformas na estrutura fundiária.

Apesar da Constituição Federal Brasileira e do Estatuto da Cidade definirem a obrigatoriedade do cumprimento da função social da propriedade, e dos Planos Diretores Municipais apresentarem diversos instrumentos urbanísticos e jurídicos com potencial de intervenção na estrutura fundiária das cidades brasileiras, mantém-se as grandes glebas e as irregularidades registrais que impedem a venda, o parcelamento e a construção, assim como continuam desocupados terrenos e edifícios em áreas bem localizadas.

Sob essas condições, o salto da produção habitacional de interesse social e de mercado popular acabou por dificultar o acesso de populações mais pobres a terras bem localizadas, reproduzindo rapidamente e em larga escala o padrão de produção do espaço nas cidades brasileiras, cuja marca é a segregação e a desigualdade sócio-territorial.

Em estudo sobre o enfoque teórico da produção acadêmica que trata do tema da habitação no Brasil, Ermínia Maricato destaca a recorrência de temáticas ligadas ao consumo e à atuação do Estado, apontando por outro lado que

é notável o desconhecimento do quadro geral da produção e distribuição e da habitação que estamos aqui denominando provisão da habitação, formado pelas diversas tipologias resultantes de diferentes arranjos entre: o financiamento, a construção, a promoção, a comercialização, a participação da força de trabalho e o lugar ocupado pela propriedade da terra no contexto da regulação instituída (e praticada de forma discriminatória no Brasil e em toda América Latina) pela legislação de uso e ocupação do solo. (MARICATO, 2009:35-36)

A hipótese desta pesquisa é que a manutenção da estrutura fundiária é o maior entrave para a produção habitacional de interesse social, e que o enfrentamento desse problema tem-se apoiado em instrumentos urbanísticos que são apropriados por interesses do capital imobiliário. Seja durante o processo de aprovação da legislação que os regulamenta, seja dificultando sua implementação por meio de intervenção junto ao sistema judiciário, a atuação do capital imobiliário é direcionada à adequação dos instrumentos urbanísticos à sua conveniência, reduzindo o potencial de transformação desses instrumentos. Dessa forma, ainda que os instrumentos cheguem a ser aplicados, resultam ineficazes para a redução da segregação territorial e das desigualdades sociais características das cidades brasileiras.

O Estatuto da Cidade, regulamentação do capítulo 182 da Constituição Federal, que trata da política de desenvolvimento urbano, levou treze anos para ser aprovado. O texto resultante desses treze anos de discussão sobre os conflitos existentes não deu conta de definir claramente a forma de cumprimento da função social da propriedade, transferindo essa decisão para os Planos Diretores Municipais. Na esfera local, os conflitos entre interesses do capital e dos trabalhadores novamente aparecem durante o processo de aprovação dos planos, e a configuração final dos instrumentos urbanísticos e suas formas de implantação resultam desse processo. Nos casos em que os instrumentos chegam a ser aplicados, acabam atuando sob a mesma lógica de desenvolvimento urbano vigente, e a segregação é reafirmada, aprofundando as diferenças sociais.

A Primeira Parte do trabalho apresenta o contexto geral da questão tratada na pesquisa realizada: as condições em que ocorreu o boom imobiliário dos anos de 2000.

No Capítulo 1, apresentamos uma caracterização do salto experimentado pela produção imobiliária residencial no Brasil a partir dos anos de 2000. Em seguida, aprofundamos a análise dos resultados da aplicação do Programa Minha Casa Minha Vida para a população de mais baixos rendimentos, grupo que hoje tem menos acesso à terra e à moradia no país. Ainda, discutimos a questão da terra no contexto do boom imobiliário residencial, e transformações de acesso ao crédito que viabilizaram esse salto na produção. 
No Capítulo 2, abrimos um parêntese para reunir alguns fundamentos históricos da formação da propriedade da terra no Brasil, caracterizando ainda a construção do padrão segregador de produção do espaço urbano no Brasil, e em seguida apresentando uma discussão sobre as formas de ocupação da terra no processo de expansão do município de São Paulo, que é objeto do estudo empírico apresentado na Segunda Parte deste trabalho.

A Segunda Parte apresenta um estudo empírico dos efeitos territoriais do boom imobiliário residencial, e desenvolve uma análise das reações do poder público municipal aos impactos negativos desse salto na produção por meio de instrumentos do planejamento urbano.

No Capítulo 3, nos aproximamos mais do objeto do estudo empírico, o município de São Paulo. Analisamos os efeitos do boom imobiliário residencial no município sob a perspectiva da variação dos usos do solo no território entre os anos de 2000 a 2010, além de caracterizarmos o padrão de produção dos empreendimentos residenciais verticais de interesse social e de mercado popular lançados no período.

No Capítulo 4, apresentamos uma análise aprofundada da Cota de Solidariedade, novo instrumento instituído pelo Plano Diretor de São Paulo de 2014 que propõe a vinculação do licenciamento de grandes empreendimentos imobiliários à produção habitacional de interesse social. Elaboramos uma avaliação do potencial da Cota de Solidariedade que parte da seguinte pergunta: se a produção imobiliária dos próximos dez anos seguisse o mesmo padrão do observado entre 2000 e 2010, qual seria o potencial de produção de HIS da Cota de Solidariedade? Para responder a essa questão, simulamos o potencial de cada uma das quatro alternativas de aplicação do instrumento tanto em termos numéricos como de localização: i) destinação de 10\% da área computável em unidades residenciais de HIS no mesmo empreendimento; ii) destinação de 10\% da área computável em unidades residenciais de HIS no mesmo empreendimento; iii) doação de terreno com valor equivalente a $10 \%$ do valor do terreno a ser licenciado; e iv) doação de $10 \%$ do valor do terreno a ser licenciado para o Fundo de Desenvolvimento Urbano - FUNDURB.
Nas Considerações Finais, concluímos que a Cota de Solidariedade apresenta potencial de intervenção na estrutura fundiária no sentido da ampliação do acesso a terras bem localizadas para a produção de habitação de interesse social. No entanto, esse potencial fica minimizado pela acomodação de interesses do capital imobiliário durante o processo legislativo do Plano Diretor, ajustando o cumprimento de uma obrigação do empreendedor à sua conveniência. 
Entre 2002 e 2013 o valor total financiado no Brasil com recursos oriundos da caderneta de poupança cresceu mais de 65 vezes, passando de 1,17 bilhões em 2002 a 76,97 bilhões em 2013. O número de unidades habitacionais financiadas no país cresceu mais de 20 vezes, de 18.615 unidades em 2002 a 365.002 em 2013. Tendo o total do valor financiado crescido em 65 vezes, e o número de unidades financiadas, em 20 vezes no mesmo período, isso indica que o valor das unidades financiadas pouco mais que triplicou entre 2002 e 2013.

\section{Gráfico 1 - Valor total financiado com recursos do SBPE entre 2002 e 2013}

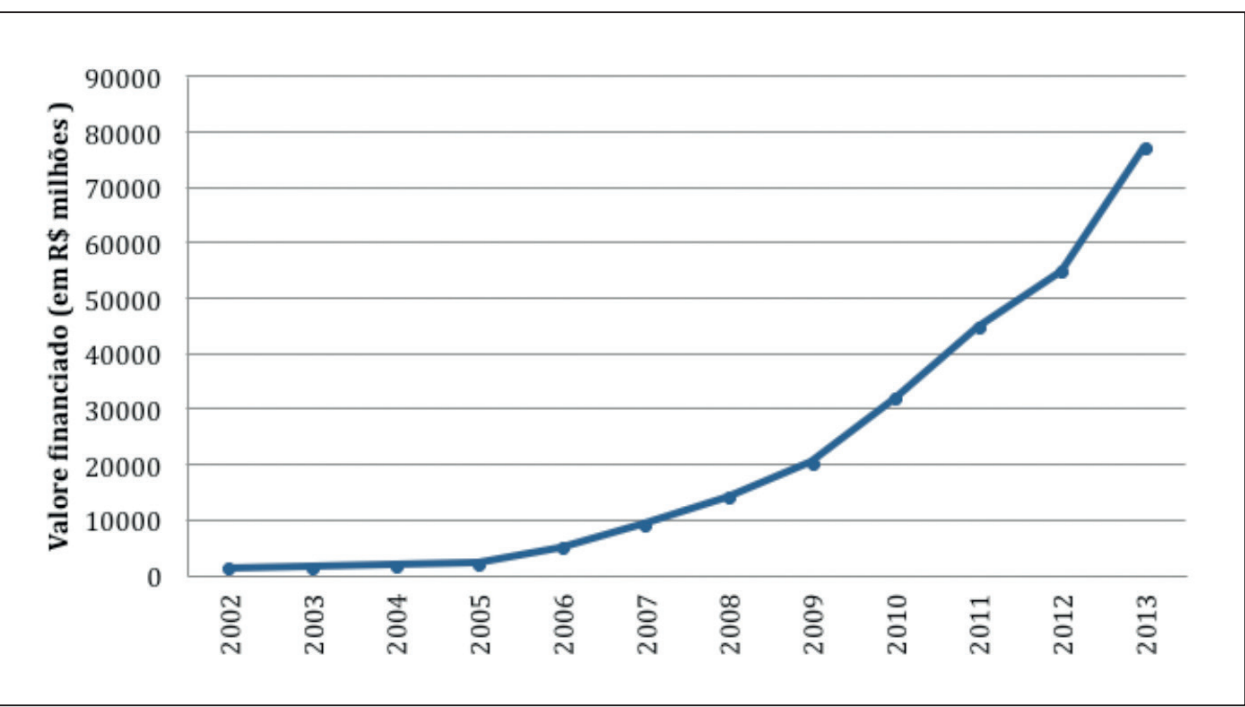

Fonte: Abecip, dados obtidos no site http://www.abecip.em setembro de 2014. Elaboraçăo da autora.

Gráfico 2 - Número de unidades financiadas com recursos do SBPE entre 2002 e 2013

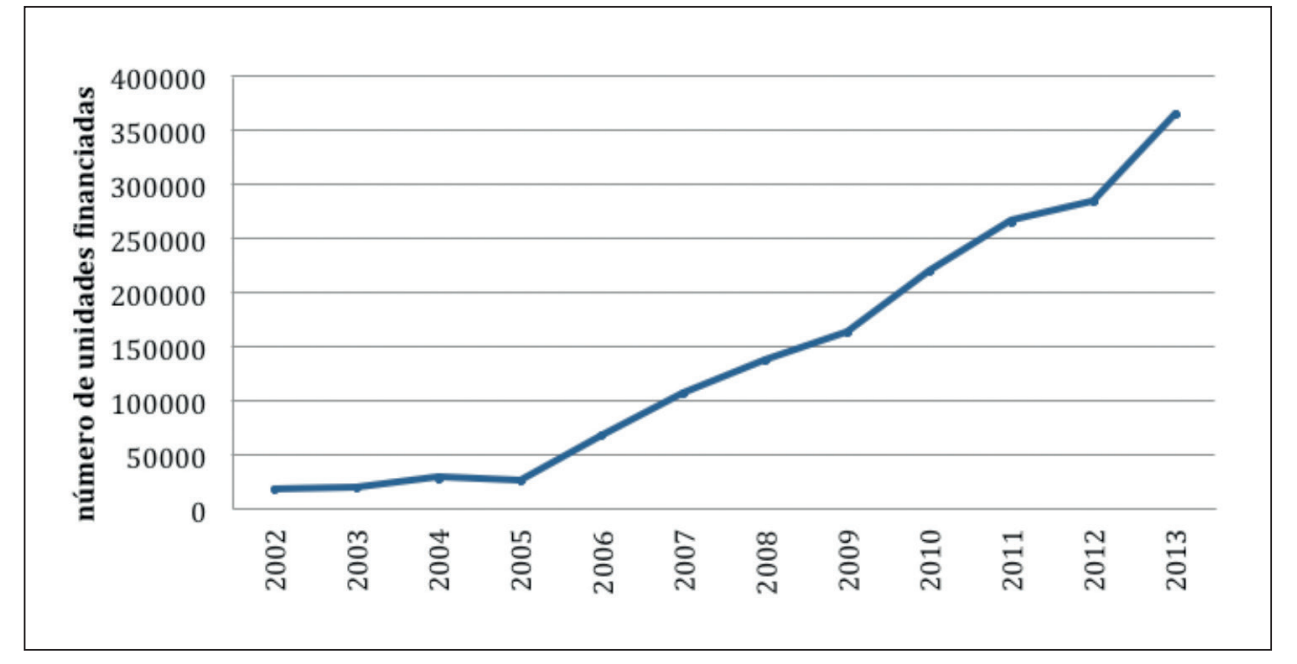

Fonte: Abecip, dados obtidos no site http://www.abecip.org.br em setembro de 2014. Elaboraç̧åo da autora
Para as camadas sociais de rendimentos mais baixos, o volume de crédito habitacional foi ampliado a partir de 2009, com o Programa Minha Casa Minha Vida - PMCMV, e a construção de unidades habitacionais de interesse social e de mercado popular ${ }^{1}$ deu um grande salto desde então.

Entre 2009 e 2012, 1,2 milhões de unidades habitacionais foram entregues pelo PMCMV. No mesmo período, o déficit habitacional foi reduzido em $8 \%$, ou em aproximadamente 450 mil moradias, ou seja, somente 37,5\% da produção do Programa atendeu à redução do déficit habitacional. Apenas $27,3 \%$ do total de unidades habitacionais produzidas pelo PMCMV nesse período foram destinadas a famílias com renda de até $\mathrm{R} \$ 1.600^{2}$, que compõem $74 \%$ do déficit habitacional no país, ainda que o equivalente a $31,1 \%$ do total de R $\$ 97,7$ bilhões de recursos desembolsados entre 2009 e 2012 pelo Programa Minha Casa Minha Vida, seja oriundo de subsídios.

De acordo com estudo realizado pela Fundação João Pinheiro³, o déficit habitacional brasileiro em 2012 era de 5,24 milhões de moradias, 74\% dele composto por domicílios com renda de até três salários mínimos . A metodologia do estudo considera o déficit habitacional

como a soma de quatro componentes: domicilios precários (soma dos domicilios improvisados e dos rústicos), coabitação familiar (soma dos cômodos e das famílias conviventes secundária com intenção de constituir um domicílio exclusivo), ônus excessivo com aluguel urbano e adensamento excessivo de domicílios alugados. ${ }^{5}$ (FJP, 2013:14)

1. As definiçōes de habitação de interesse social e habitação de mercado popular utilizadas neste trabalho são as constantes do Decreto 44.667/04, que dispōe, entre outros assuntos, sobre normas especificas para a produção de Habitação de Interesse Social e Habitaçáa do Mercado Popular

àquela destinada a familia com renda igual ou inferior a 6 (seis) saláios mínimos, de promoção pública ou conveniada ao Poder Público, nos termos do disposto no Capítulo IV do decreto

列 salários mínimos, de promoçăo privada, nos termos do disposto no Capítulo VI do Decreto 44.667/04.

2. Cartilha Programa Minha Casa Minha Vida, Ministério das Cidades, 2013.

3. Indicador desenvolvido pela Fundação João Pinheiro com base em dados da Pesquisa Nacional por Amostra de Domicilios - PNAD, elaborada anualmente pelo Instituto Brasileiro de Geografia Estatística - IBGE.

4. Pesquisa Nacional por Amostra de Domicilios - PNAD, elaborada anualmente pelo Instituto Brasileiro de Geografí
Estatistica - BGE 2012 . Estatística - IBGE, 2012

5. De acordo com a metodologia do estudo sobre o deficit habitacional no Brasil, "O conceito de domicilios improvisados 
Tabela 1 - Déficit habitacional na Região Metropolitana de São Paulo por componente

\begin{tabular}{lcccc}
\hline & $\begin{array}{c}\text { Domicilios } \\
\text { precários }\end{array}$ & Coabitação & $\begin{array}{c}\text { Onus excessivo } \\
\text { com aluguel }\end{array}$ & $\begin{array}{c}\text { Adensamento } \\
\text { excessivo }\end{array}$ \\
\hline Número absoluto & 48.762 & 334.066 & 298.489 & 111.731 \\
\hline Porcentagem & $6,1 \%$ & $42,1 \%$ & $37,6 \%$ & $14,1 \%$ \\
\hline
\end{tabular}

Fonte: $₹ \mathrm{JP}, 2013$

O déficit habitacional tem sido utilizado como argumento para a legitimação de uma política habitacional voltada à produção residencial em grande escala por empresas privadas, por meio do Programa Minha Casa Minha Vida, como apontam José Eduardo Baravelli (2014) e Ermínia Maricato (2009a).

A produção habitacional resultante do Programa Minha Casa Minha Vida é massiva, como visto nos números acima, no entanto não atende às camadas da população que têm mais dificuldades de acesso à moradia.

\section{Imagem 1 - Unidades habitacionais do Programa Minha Casa Minha Vida em Campinas}

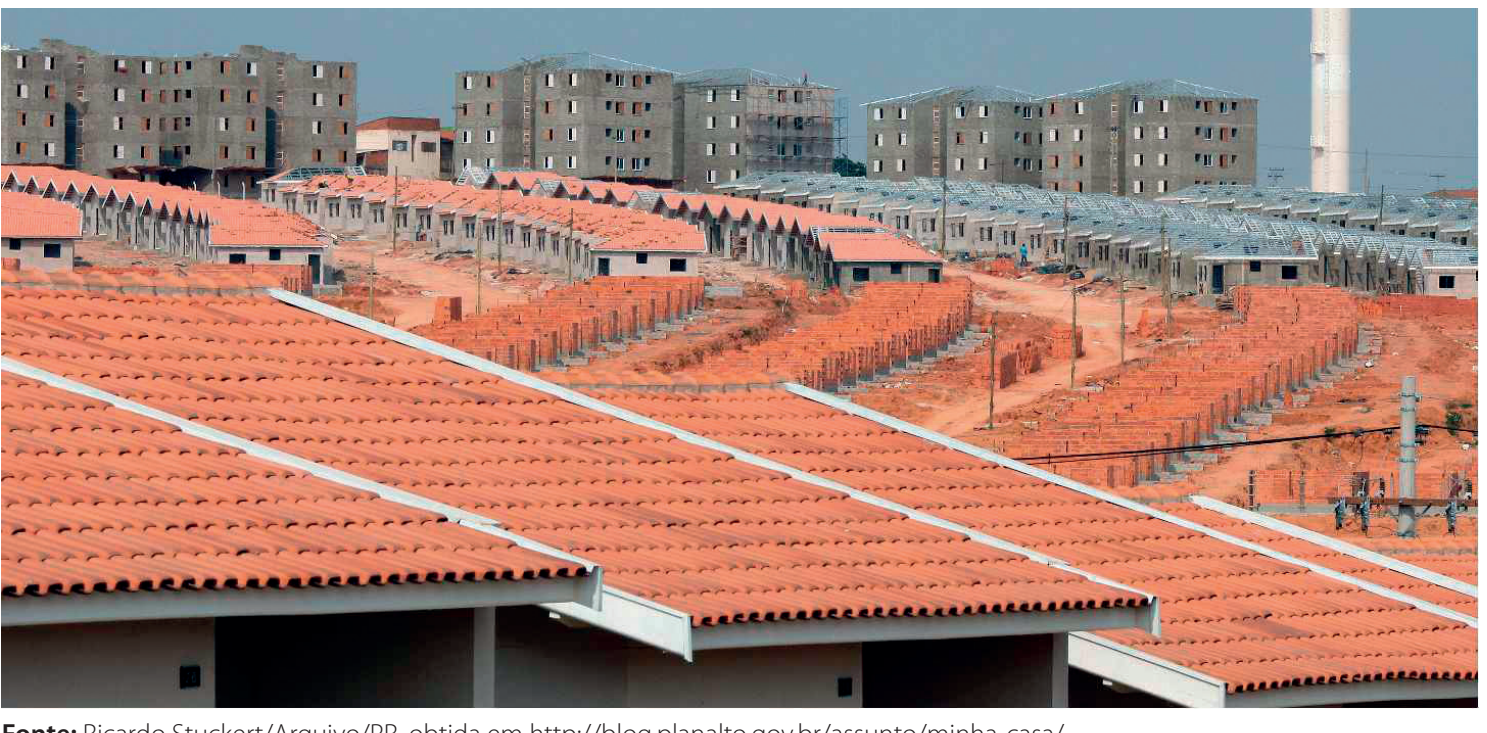

Fonte: Ricardo Stuckert/Arquivo/PR, obtida em http://blog.planalto.gov.br/assunto/minha-casa/

engloba todos os locais e imóveis sem fins residenciais e lugares que servem como moradia alternativa (imóveis comerciais, de novas unidades domiciliares. (...) os domicílios rústicos são aqueles sem paredes de alvenaria ou madeira aparelhada. (...) os cômodos são domicílios particulares compostos por um ou mais aposentos localizados em casa de cômodo, cortiço, cabeça-de-porco - entre outros. (...) O ônus excessivo com aluguel urbano corresponde ao número de famililas urbanas com


mero médio de moradores por dormitório acima de três. O número de dormitórios corresponde ao total de cômodos que servem de dormitório em caráter permanente e apenas para os moradores do domicilio" (FIP, 2103:14-19)
O Programa organiza o atendimento em três faixas de rendimentos. A faixa 1 é composta por famílias com renda mensal de até $\mathrm{R} \$ 1.600$, que recebem subsídio para aquisição da moradia, e pagam o equivalente a 5\% da renda mensal durante 10 anos. Para essa faixa de renda foram desembolsados $\mathrm{R} \$ 21,5$ bilhões, ou $22 \%$ do total. A faixa 2 atende famílias com renda mensal de até $\mathrm{R} \$ 3.275$, e recebe subsídio parcial e financiamento com juros reduzidos. Para essa faixa de renda foram desembolsados $\mathrm{R} \$ 66,8$ bilhões, $68 \%$ do total. A faixa 3 é formada por famílias com renda de até $\mathrm{R} \$ 5.000$ por mês, tem acesso a financiamento, e teve desembolso de R $\$ 8,9$ bilhões, $9 \%$ do total.

Tabela 2 - Recursos destinados ao PMCMV por faixa de atendimento entre 2009 e 2012

\begin{tabular}{lccc}
\hline & Faixa 1 & Faixa 2 & Faixa 3 \\
\hline Rendimento familiar & zero a $\mathrm{R} \$ 1.600,00$ & $\mathrm{R} \$ 1.600,01$ a $\mathrm{R} \$ 3275,00$ & $\mathrm{R} \$ 3.275,01$ a $\$ \$ 5.000,00$ \\
\hline Investimento no período & 21,5 bilhöes & 68,8 bilhōes & 8,9 bilhões \\
\hline $\begin{array}{l}\text { Porcentagem em relação } \\
\text { ao total de investimento }\end{array}$ & $22 \%$ do total & $68 \%$ do total & $9 \%$ \\
\hline
\end{tabular}

Fonte: Cartilha Programa Minha Casa Minha Vida, Ministério das Cidades, 2013.

Tabela 3 - Unidades entregues pelo Programa Minha Casa Minha Vida entre 2009 e junho de 2013

\begin{tabular}{lcc}
\hline Faixa de rendimentos mensais & Unidades entregues & $\%$ \\
\hline Faixa 1 - até $\mathrm{R} \$ 1.600,00$ & 340.774 & $27,3 \%$ \\
\hline Faixa 2 - de $R \$ 1.600,01$ até $R \$ 3.275,00$ & 822.361 & $65,9 \%$ \\
\hline Faixa 3 - de $R \$ 3.275,01$ até $R \$ 5.000,00$ & 84.724 & $6,8 \%$ \\
\hline Total & $\mathbf{1 . 2 4 6 . 8 5 9}$ & $\mathbf{1 0 0 \%}$ \\
\hline
\end{tabular}

Fonte: MCidades, 2013.

Os dados apresentados mostram que as condições de produção habitacional de interesse social estabelecidas pela política nacional resultam em moradias que não atendem ao principal grupo da demanda, ainda que haja subsídio, crédito e volume de unidades produzidas. 


\section{1 - Condições de acesso à terra no contexto do boom imobiliário residencial}

A busca de terras é a primeira etapa do processo de produção habitacional, de promoção tanto pública como privada, e é determinante das etapas seguintes, assim como do tempo total de desenvolvimento do empreendimento até sua entrega.

Na categoria de produção pelo mercado privado, um potencial negócio se inicia pela identificação de um terreno disponível para venda, por meio da oferta por corretores de imóveis ou de proprietários aos gestores de novos negócios das incorporadoras.

Em seguida, são iniciados estudos de viabilidade física, com a pesquisa de legislação urbanística, edilícia e ambiental e um estudo de implantação do programa do empreendimento: unidades habitacionais horizontais ou verticais, garagens, áreas permeáveis, espaços de uso coletivo etc; e viabilidade econômico-financeira, em que são modelados receitas próprias e de financiamento, gastos com aquisição do terreno por compra ou permuta, gastos de construção, margem de lucro e eventuais gastos extra por conta de atrasos até o lançamento das vendas das unidades do empreendimento. Nessa etapa, a legislação ambiental, urbanística e edilícia são fundamentais para definir o número de unidades do empreendimento e o prazo previsto entre a negociação do terreno e o lançamento do produto imobiliário. A análise de riscos de possíveis atrasos é fundamental para a decisão de iniciar ou não o negócio.

Gráfico 3 - Etapas da produção habitacional pelo mercado privado

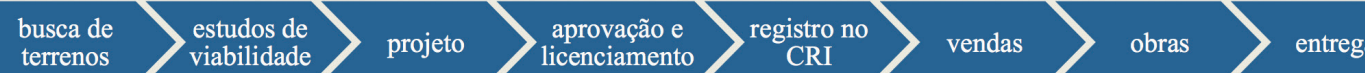

Elaboraçăo da autora, com base em entrevista com Gestor de Novos Negócios de empresa incorporadora que atua nas faixas 2 e 3 do Programa Minha Casa Minha Vida, realizada em 07.07.2014.
Em entrevista realizada em com Gestor de Novos Negócios de uma incorporadora que atua nas faixas 2 e 3 do Programa Minha Casa Minha Vida, ele esclarece a composição do custo dos empreendimentos:

Temos o custo do terreno, custo da obra, custos operacionais de aprovação de projeto, com custos de emolumentos e impostos. Isso tudo somado, chegamos ao preço de venda do produto. E há os parâmetros que a empresa busca. Cada empresa tem o seu parâmetro. Em geral, tentamos buscar uma lucratividade que gira em torno de 15 a $16 \%$.

Com o valor de venda máximo das unidades fixado pelo Programa Minha Casa Minha Vida em R\$190.000,00 nas faixas 2 e 3, e considerando que a margem de lucro da incorporadora não varie, o preço máximo que a incorporadora se dispõe a pagar pelo terreno é orientado pelo número de unidades implantadas e pelos custos de obras e aprovação de projetos. A localização é fundamental para a definição do preço do terreno nas faixas 2 e 3 de atendimento do Minha Casa Minha Vida, uma vez que custos de obras e de licenciamento variam diretamente com características físicas do terreno e de sua localização, como a necessidade de terraplenagem ou de extensão de redes de infraestrutura, e a existência de faixas não edificantes por motivo de proteção ambiental, entre outros.

A localização é menos determinante do preço dos terrenos na Faixa 1 que nas Faixas 2 e 3 de atendimento do Minha Casa Minha Vida, visto que na Faixa 1 a demanda é garantida, e nas Faixas 2 e 3 há concorrência de preços e localizações entre diversos empreendimentos.

Nas Faixas 2 e 3, os projetos são apresentados por empresas do setor imobiliário às instituições financeiras operadoras do crédito (Banco do Brasil e Caixa Econômica Federal - $\mathrm{CEF),} \mathrm{que} \mathrm{liberam} \mathrm{os} \mathrm{recursos} \mathrm{à} \mathrm{de} \mathrm{acordo} \mathrm{com} \mathrm{o} \mathrm{cronograma} \mathrm{de} \mathrm{compra} \mathrm{de} \mathrm{terreno} \mathrm{e}$ de construção, e alienam os imóveis diretamente aos compradores, com subsídio parcial em financiamentos pelo Fundo de garantia por tempo de serviço - FGTS, ou com acesso ao Fundo Garantidor da Habitação. 
Na Faixa 1, municípios e estados podem adquirir terrenos por meio de compra ou desapropriação. A desapropriação permite a aquisição de terrenos com irregularidades registrais, pois após concluído o processo judicial, é aberta uma nova matrícula, sem restrições ao parcelamento, construção ou alienação. Nessa faixa de atendimento, construtoras apresentam propostas de projetos à Caixa Econômica Federal, e se aprovados, os terrenos serão doados ao Fundo de Arrendamento Residencial - FAR, e os recursos para a construção, liberados de acordo com o cronograma. A demanda é cadastrada previamente pelo poder público local, e compra os imóveis junto à CEF com subsídio integral, isenção de seguro e pagamento mensal de até $10 \%$ da renda (mínimo de $\mathrm{R} \$ 50$ por mês), por 10 anos.

Gráfico 4 - Composição do valor de venda da Unidade Habitacional no Programa Minha Casa Minha Vida

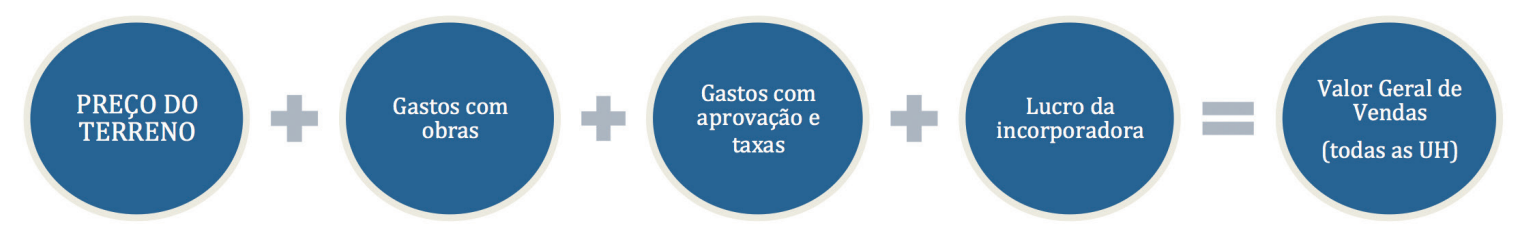

Elaboração da autora, com base em entrevista com Gestor de Novos Negócios de empresa incorporadora que atua nas faixas 2 e 3 do Programa Minha Casa Minha Vida, realizada em 07.07.2014.

José Eduardo Baravelli, em sua tese de doutorado, estuda as condições de produção habitacional sob as regras do Programa Minha Casa Minha Vida, especificamente a Faixa 1, e identifica a atuação complementar de empresas incorporadoras e construtoras que atuam em mais de uma modalidade do Programa. Sobre o papel da terra no Minha Casa Minha Vida, o autor destaca que

nem a empresa construtora nem a CEF obtém na Faixa 1 do programa MCMV o valor associado à localização urbana da unidade habitacional construída, a "renda diferencial" que é a essência do lucro de incorporação.(...) A localização que é desvalorizada (e, assim, desconsiderada) nos empreendimentos da Faixa 1 do programa MCMV volta a ter valor, no entanto, para as linhas de financiamento da Faixa 2 e Faixa 3. (Baravelli, 2014: 181)
Para que a produção nas Faixas 2 e 3 do PMCMV se concretize, os terrenos objeto de empreendimentos devem obrigatoriamente ser adquiridos segundo parâmetros legais de registro imobiliário. A garantia para o financiamento da construção é a alienação fiduciária do próprio imóvel, ou seja, em caso de inadimplência no pagamento do financiamento, a empresa incorporadora perde a posse e o domínio do imóvel, que são retomados pelo banco credor.

As terras cuja condição jurídica permitem a obtenção de crédito para produção habitacional realizada pelo mercado privado estão localizadas na chamada "cidade formal". A condição de regularidade jurídica e registral da terra restringe a produção imobiliária formal a trechos de cidade onde o processo de ocupação produziu terras urbanizadas e regularizadas, configurando uma grande área de exceção ao crédito que pode ser maior que a própria área onde ele é aplicável.

Tomando o município de São Paulo como exemplo, onde estima-se que aproximadamente 70\% do território tenha sido produzido de forma irregular ${ }^{6}$, vemos no mapa a seguir que essas áreas estão localizadas principalmente no centro expandido do município.

O Programa Minha Casa Minha Vida - Faixa 1 admite a aquisição de terras com irregularidades nos registros de propriedade por meio do processo judicial de desapropriação. Ao final do processo de desapropriação, o título que continha irregularidades é extinto e uma nova matrícula é aberta, com todas as condições legais para que sejam feitos parcelamentos, incorporações, construções e alienações.

A possibilidade de aquisição de terrenos irregulares pelos municípios e estados e disponibilização dessas terras para a produção formal é um importante efeito do Programa Minha Casa Minha Vida. Por um lado, imprime uma velocidade muito lenta à viabilização dos empreendimentos da Faixa 1, uma vez que processos de desapropriação são usualmente demorados. Por outro lado, funciona como uma espécie de ferramenta de atalho nos procedimentos de regularização fundiária. 
Mapa 1 - Localização das favelas e loteamentos irregulares no município de São Paulo
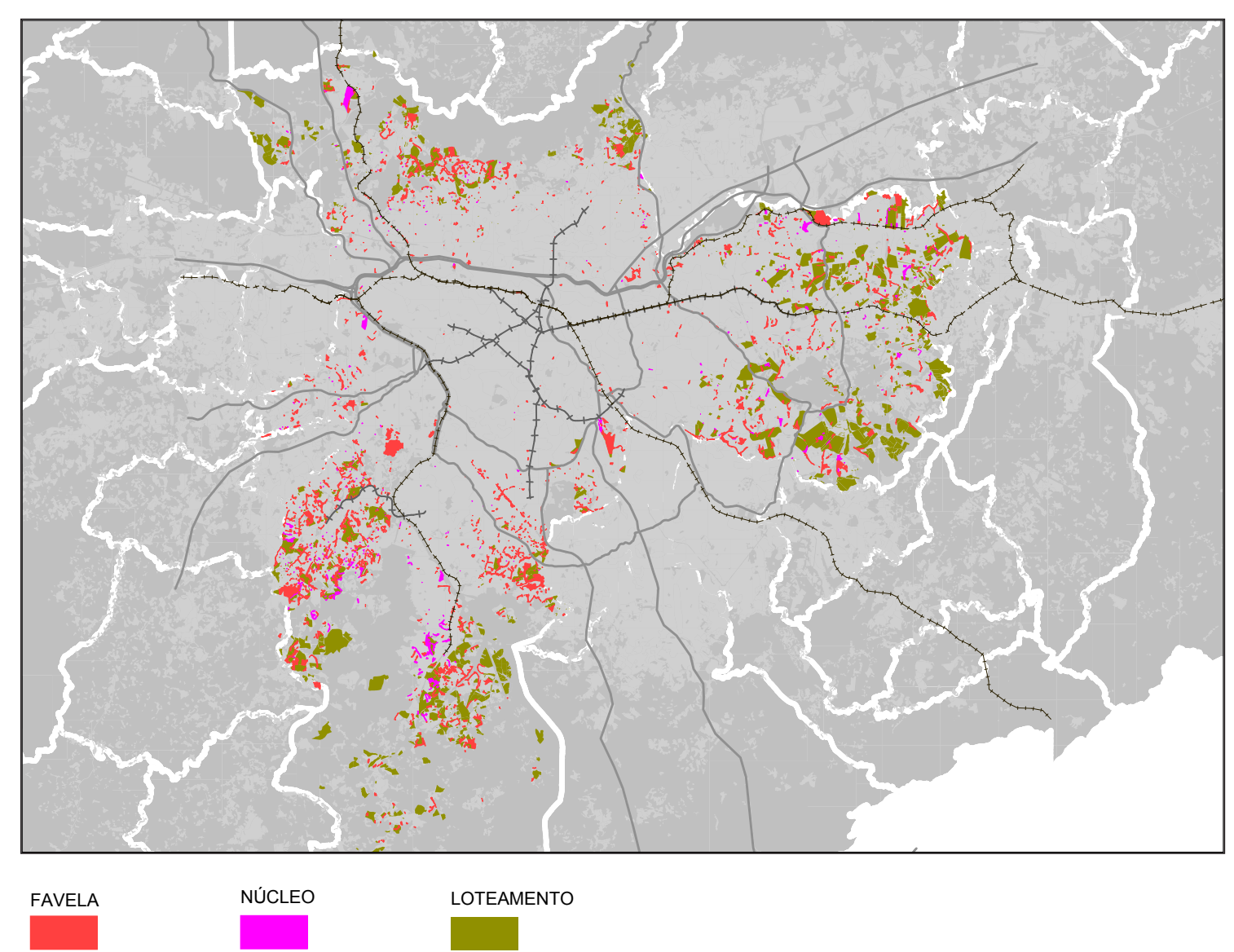

Fonte: SEHAB/HAB// Sistema de Consulta HABISP2013. Elaboraçăo de Edson Capitânio.

Imagem 2 - Empreendimento Minha Casa Minha Vida construído em terrenos remanescentes de conjuntos da COHAB-SP em Itaquera

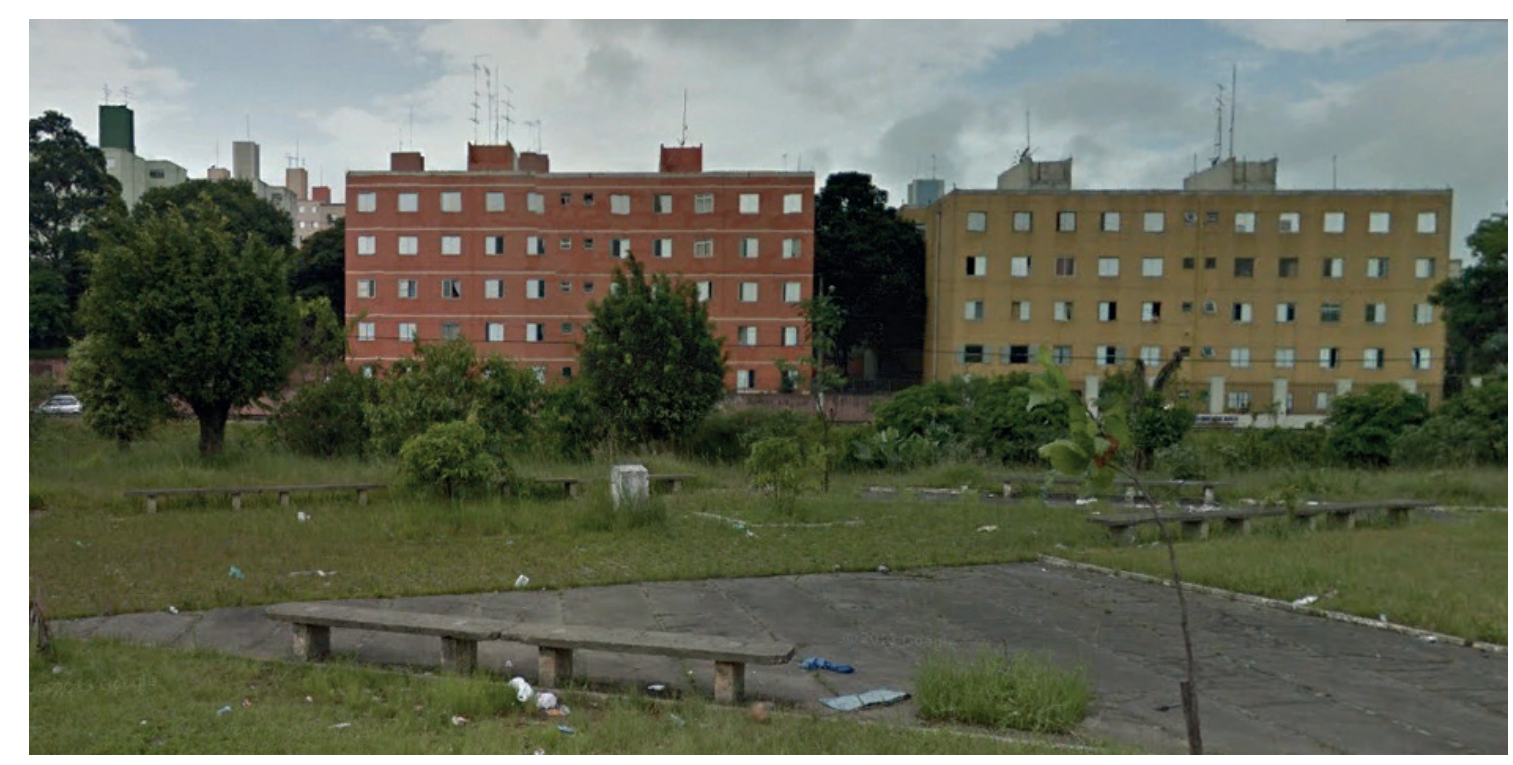

Fonte: Google Street View, 2015.
Processos de desapropriação são custosos e lentos, e por isso não barateiam o custo da terra, ainda que possam facilitar o acesso a ela para a produção habitacional de interesse social, como nos casos de glebas irregulares que somente entram no mercado residencial formal por meio da desapropriação e produção pela Faixa 1 do PMCMV.

A pesquisa "Preço de desapropriação de terras: limites às políticas públicas nas áreas de habitação, meio-ambiente e vias públicas em São Paulo", realizada em 2001 pelo Laboratório de Habitação e Assentamentos Humanos da Faculdade de Arquitetura e Urbanismo da Universidade de São Paulo - LabHab/FAUUSP, coordenada por Ermínia Maricato, elaborou uma análise do custo de desapropriações para o poder público e as limitações que gera para a implantação de políticas sociais. O relatório da pesquisa aponta que

Os valores pagos nas desapropriações representam uma porcentagem significativa do orçamento dos municípios e dos estados brasileiros. Muitas vezes, o valor de uma superindenização de desapropriação de terra equivale ao orçamento geral de um ou mais mandatos políticos de uma instância de governo. (...) Facilitar o acesso à terra e baratear o seu custo, para a implementação de políticas públicas, são metas fundamentais para qualquer desenvolvimento democrático, tanto no campo quanto nas cidades brasileiras. Desobstruir processos arcaicos de regulação fundiária históricos e estruturais - é um desafio essencial, que vem sendo travado para a busca da diminuição das desigualdades sociais e a aquisição de uma cidadania digna e menos restrita a uma parcela da sociedade. (...) A propriedade da terra tem funcionado como um expediente central atribuidor de poder. Esse fato fica evidenciado nos exagerados preços de desapropriação de terra para fins de interesse social, por mais que a década de 90 tenha se caracterizado pela redução do valor real da terra, tanto urbana quanto rural (BLECKER, 2000). Em ambos os horizontes, a questão fundiária é crucial para o desenvolvimento de políticas públicas visando a equidade social em relação à propriedade da terra. (MARICATO, 2001:6-7)

Muito diferente do que se almejaria na aplicação de um programa que é parte do Plano Nacional de Habitação, cujo objetivo é "propor medidas de política urbana e fundiária capazes de facilitar e baratear o acesso à terra urbanizada para Habitação de Interesse Social" (MCidades, 2009:13), o Programa Minha Casa Minha Vida promove o espraiamento ainda maior das áreas urbanas ocupadas, mas não necessariamente urbanizadas, por meio da implantação de conjuntos habitacionais para populações de baixos rendimentos. 
Sem que haja necessidade de planos, programas e projetos, mas sem prescindir de recursos financeiros públicos vultuosos para a desapropriação de terras privadas, o Programa Minha Casa Minha Vida promove a inserção no mercado oficial de habitação de interesse social de grandes glebas periféricas que nem sequer foram parceladas, não receberam acesso a serviços de infraestrutura, e são apartados da urbanização consolidada.

\section{2 - Reformas no sistema de financiamento como preparação para o boom} imobiliário

O salto na produção imobiliária habitacional a partir dos anos 2000 foi fortemente amparado pela construção de um ambiente regulatório que proporcionasse mais segurança aos credores, viabilizando a ampliação da oferta de financiamento e crédito imobiliário.

Luciana Royer, em sua tese de doutorado, traça uma análise do funcionamento do Sistema Financeiro de Habitação - SFH e do Sistema Financeiro Imobiliário - SFI ao longo do tempo e seus reflexos na política pública de habitação no Brasil. Ela ressalta a importância da criação da estrutura de financiamento habitacional após o golpe militar de 1964 - além do SFH, também o Sistema Brasileiro de Poupança e Empréstimo - SBPE e o Fundo de Garantia do Tempo de Serviço - FGTS, apesar dessa política ter resultado em unidades habitacionais principalmente para as camadas de rendimentos médios e altos da população. Com o fortalecimento do modelo econômico neoliberal no Brasil, na década de 1990, o modelo do SFH foi alterado, e complementarmente foi introduzido o Sistema Financeiro Imobiliário -SFI.

Centrado na captação de recursos privados via mercado de capitais, foi lançado, em 1997, o Sistema de Financiamento Imobiliário (SFI), aportando a racionalidade das finanças na organização do financiamento da politica de crédito imobiliário, inclusive o habitacional. Ao contrário do sistema anterior, apoiado em um funding público, o SFI buscava deslanchar o crédito imobiliário com o uso de instrumentos financeiros inovadores como o Certificado de Recebiveis Imobiliários (CRI), a Letra de Crédito Imobiliário (LCI) e a Cédula de Crédito Imobiliário (CCI), buscando introduzir, ainda que em menor escala, um mercado de financiamento habitacional semelhante ao modelo norte-americano, provendo as condições necessárias ao desenvolvimento de um mercado secundário de hipotecas, que teria como função primordial transformar a concessão de crédito imobiliário num investimento dotado de segurança e liquidez. (Royer, 2009:15)

O governo nacional proveu a regulação que permitiu a capitalização do setor imobiliário com recursos do mercado de capitais, por meio dos novos títulos financeiros, assim como a segurança para a oferta de crédito por meio de garantias como a alienação fiduciária.

A alienação fiduciária traz uma mudança importante na estrutura jurídica de propriedade imobiliária no país, na medida em que altera o regime de propriedade de um imóvel financiado. O financiador mantém a propriedade do imóvel até a quitação total da dívida do mutuário, que no período de pagamento do financiamento, permanece somente com a posse, e não com a propriedade, desse imóvel. A principal segurança de garantia para o investidor que a alienação fiduciária traz é a redução do prazo necessário para a retomada do imóvel em caso de inadimplência. Comparada à hipoteca, cujo prazo de retomada de um imóvel gira em tordo de dez anos, no caso da alienação fiduciária é de aproximadamente seis meses ${ }^{7}$.

Com a instituição de novas garantias ao crédito, os imóveis objeto de financiamento ficam menos tempo fixados ao sistema de propriedade tradicional, e a renda da terra é mais facilmente captada por meio de ganhos de juros. Com os novos instrumentos financeiros de investimento, como o Certificado de Recebíveis Imobiliários - CRI, a Letra de Crédito Imobiliário - LCI e a Cédula de Crédito Imobiliário - CCI, empresas incorporadoras imobiliárias que abriram seu capital na bolsa de valores ficam capitalizadas para a compra de terrenos que servirão de base material para a produção imobiliária e garantirão ganhos maiores que outras opções de investimento de capital a juros. 
David Harvey define a cidade como "ao mesmo tempo produto e condição de processos sociais de transformação vigentes na fase mais recente do desenvolvimento capitalista" (Harvey, 1996:48). No Brasil, o aporte de recursos a empresas incorporadoras imobiliárias por meio da abertura de capital na Bolsa de Valores viabilizou a formação de estoques de terrenos privados dessas empresas, e proporcionou uma posição privilegiada a empreendedores no processo de produção das cidades. Isso reflete um movimento presente em diversos países, onde incorporadores imobiliários "frequentemente se unem para se tornarem o agente que lidera a política da máquina do crescimento ${ }^{8}$ (Harvey, 1996:52).

Mariana Fix, em sua tese de doutorado, faz um estudo sobre as transformações do setor imobiliário no Brasil a partir dos anos de 2000, concluindo que

A criação desses mecanismos modifica a forma jurídica da propriedade imobiliária e, consequentemente, as modalidades de apropriação da renda da terra. As formas renda e juros aproximamse em um único ativo financeiro de base imobiliária. Um sistema que, com vimos, ano a ano vai sendo ajustado (aperfeiçoado, nos termos dos seus defensores) de modo a libertar os imóveis para a circulação do capital portador de juros e vincular os mercados de terra e imóveis, os usos do solo, e a organização espacial em um processo geral de circulação de capital, como mencionamos na introdução. (Fix, 2011:181)

A aquisição de terrenos por empresas incorporadoras imobiliárias é fundamental para girar a engrenagem da capitalização por meio de acionistas do mercado financeiro. A Cyrela foi apontada em estudo da Corretora Votorantim de 2010 como a empresa com maior estoque de terrenos, equivalente a 38 bilhões de reais, o dobro da segunda maior empresa em estoque 9 . Somente no primeiro trimestre de 2010, essa incorporadora e construtora imobiliária adquiriu 420 milhões de metros quadrados em diversas regiões do país ${ }^{10}$.
Esse estoque de terras funciona como um lastro, uma base material para a produção potencial de 1,3 bilhão em Valor Geral de Vendas, para atrair investimentos por meio da bolsa de valores, um "capital fictício, uma promessa de ganhos futuros antecipando o que poderá ser construído nos terrenos adquiridos”. (Fix, 2011:195)

O processo de produção do espaço urbano é liderado pelo setor imobiliário por meio do controle do acesso à terra, que, como vimos acima, varia de acordo com interesses ligados à circulação do capital e com condições como a disponibilidade de crédito para alguns setores e a demanda com acesso a financiamento para aquisição de produtos específicos ${ }^{11}$. 
CAPÍTULO 2

Fundamentos históricos da propriedade da terra no Brasil 
Historicamente, o acesso à terra no Brasil é restrito a poucos grupos sociais. No período colonial, o regime de sesmarias apoiou-se na concessão de posse de terras de propriedade da Coroa Portuguesa a quem apresentasse capacidade de investimento de capital na produção agrícola.

A possibilidade de reversão da posse à Coroa representou uma tentativa de garantir o uso produtivo das terras, que foi no entanto neutralizada pelo caráter predatório da produção mercantil escravista, estimuladora do latifúndio. Nas palavras de Roberto Smith, em seu livro Propriedade da terra e transição, "Compram-se escravos para comprar mais escravos. O escravo é riqueza e substrato de status da classe proprietária, é garantia de dívida. O escravismo conduz ao latifúndio, e não o inverso" (Smith, 2008:341).

A ausência de propriedade das terras na colônia não prejudicou os ganhos da metrópole, visto que o que dava lastro ao crédito mercantilista era a propriedade privada dos escravos, não de terras. Nas palavras de Smith,

o padrão relevante de acumulação foi sempre o da acumulação escravista e o escravo era a forma de riqueza que garantia a inserção na esfera mercantil. O escravo, e não a terra, tinha valor mercantil. O capital comercial e o capital traficante atuam de forma a manter o produtor escravista dependente, através de endividamento, num conjunto de relações baixamente monetarizadas, que era funcional em não permitir o desenvolvimento de um sistema financeiro e bancário. (Smith, 2008:341-342)

Em seu livro O cativeiro da terra, José de Souza Martins compara o investimento colonial de capital na compra de escravos à renda territorial capitalizada do capitalismo, considerando que o proprietário do escravo, assim como o proprietário da terra, espera extrair do seu investimento (na compra de escravo ou de terras) um rendimento econômico no mínimo equivalente ao rendimento que seu dinheiro teria se aplicado em outro negócio. a extração de lucro antes que o trabalhador começasse a produzir, representando, pois, um adiantamento de capital, ele não entrava no processo de trabalho como vendedor de mercadoria forçade-trabalho e sim como equivalente de capital, como renda capitalizada. A exploração da força de trabalho se determinava, pois, pela taxa de juros no mercado de dinheiro, pelo emprego alternativo do capital nele investido antecipadamente, isto é, o cálculo capitalista da produção era mediado por fatores e relações estranhos à produção.

Nesse sentido, as relações de produção entre o senhor e o escravo produziam, de um lado, um capitalista muito específico, para quem a sujeição do trabalho ao capital não estava principalmente baseada no monopólio dos meios de produção, mas no monopólio do próprio trabalho, transfigurado em renda capitalizada. (Martins, 2004: 15)

O autor usa a expressão "mudar para manter" para definir os reais objetivos do processo brasileiro de transição para o capitalismo. A generalização da liberdade humana aliada ao "cativeiro da terra", serviu tanto como condição fundamental para transição ao capitalismo no Brasil como para a manutenção do poder econômico escravista. A capacidade de produção a anteriormente ligada à propriedade de escravos, passa então a ser exercida por meio da manutenção e ampliação do monopólio da propriedade fundiária

O advento do capitalismo não fez cessar essa irracionalidade. Ao contrário, a propriedade fundiária, ainda que sob diferentes códigos, foi incorporada ao capitalismo, contradição essa que se expressa na renda capitalista da terra. Tal renda nada mais tem a ver com o passado pré-capitalista não é mais um tributo individual e pessoal do servo ao senhor; agora é um pagamento que toda a sociedade faz pelo fato de que uma classe preserva o monopólio da terra. (Martins, 2004:20)

A longa transição ao capitalismo brasileiro foi iniciada a partir de 1850, com a combinação entre a Lei Eusébio de Queirós, que proibiu o tráfico de escravos, e a Lei de Terras, que definiu que a aquisição de terras não mais se daria por meio de concessões, mas somente pela compra.

A expressão "mudar para manter", utilizada por José de Souza Martins, é refletida também na falta de resistência das classes dominantes da época a essas duas leis, visto que ficou garantida a reestruturação da sociedade brasileira para a entrada no capitalismo, no entanto mantendo os mesmos "donos do poder" do período anterior 
Roberto Smith, em sua análise do processo de instituição da Lei de Terras, descreve essa postura das elites da época:

a proposta de que as terras passassem a ser vendidas foi aceita sem muitas restrições pelos deputados, porque não tocava nos aspectos melindrosos da regularização do apossamento indiscriminado do passado recente e remoto. São várias, aliás, as propostas no sentido de que o passado deveria permanecer como estava, contemplando a legislação apenas o que viesse pela frente. Tais propostas pareciam desconhecer que era necessário discriminar as terras estatais, o que implicava consequentemente mexer no passado. (Smith, 2008:310)

A Lei de Terras, legislação que fundamentou a transição para o regime de propriedade privada da terra e para a instalação do capitalismo no Brasil, definiu que todas as terras ocupadas teriam a propriedade privada em nome de seus posseiros anteriores, e também que as terras não tituladas como propriedade privada passariam a ser terras de propriedade pública. O texto da lei diz que

Serão legitimadas as posses mansas e pacíficas, adquiridas por ocupação primária, ou havidas do primeiro ocupante, que se acharem cultivadas, ou com princípio de cultura e morada habitual do respectivo posseiro, ou de quem o represente. (\$1 do Art. 5 da Lei no 601 , de 18 de setembro de 1850)

No livro The Urban Experience, ao falar das condições gerais de transição para o regime capitalista, aplicáveis a diversos países do mundo, David Harvey lembra que, a terra, tanto pública como privada, sempre poder ser usada como meio de produção, e por isso somente após a privação do trabalhador ao livre acesso à terra o capitalismo pôde seguir seu caminho.

Para que se estabeleça o trabalho assalariado, o livre acesso à terra deve ser proibido ao trabalhador. Nessa perspectiva, percebemos a barreira entre trabalho e terra, configurada pela propriedade privada da terra, é socialmente necessária para a perpetuação do capitalismo. ${ }^{1}$ (Harvey, 1989:92)
O autor coloca em seguida a provocação de que a renda da terra serve como uma forma de recompensa aos proprietários por manterem a inviolabilidade da propriedade privada dos meios de produção no capitalismo².

Em seu ensaio A terra como capital (ou a terra-localização), publicado originalmente em 1985 e reeditado em 2011, Flavio Villaça aprofunda-se no estudo dos conceitos de terra-localização, de valor e de preço da terra. A investigação que ele realiza aponta para a localização como o fator definidor do valor e do preço da terra urbana, e propõe a utilização do termo "terra-localização", complementarmente aos "terra-matéria" e "terra-capital", cunhados por Marx.

Villaça consolida a noção construída por Marx ${ }^{3}$ de que terra é capital fixo quando há capital incorporado a ela sob forma de uma rede de infraestruturas, equipamentos, serviços e acesso a empregos, lazer, cultura etc. A produção do ambiente urbano resulta em localizações mais ou menos providas ou próximas dessas infraestruturas, equipamentos e serviços, e essa diferenciação é incorporada ao preço da terra como capital fixo (Villaça, 2011).

Esse sistema de recursos é que configura uma localização específica, e a aquisição de uma terra em determinada localização seria comparável à compra de um ticket a partir do qual se tem acesso à cidade. $\mathrm{O}$ autor compara, ainda, as localizações com "antiguidades e obras primas, que são produtos do trabalho humano, mas não podem ser reproduzi das por ele". O valor da localização é indissociável do valor da terra, assim como o valor da terra nunca desconsidera o valor da localização. Assim, o preço da terra localização é formado por uma complexa combinação de circunstâncias que não são controláveis o que resulta que "todo proprietário de uma terra-localização é proprietário de um bem único, irreproduzível” (Villaça, 2011:37-38)
2. Ver Harvey, 1989

3. Villaça, 2011:31, cita Marx, 1967, v.3, p. 622 


\section{1 - O padrão de ocupação da terra no Brasil: patrimonialismo} e segregação socioterritorial

As questões que envolvem o funcionamento da propriedade fundiária e das vantagens que ela confere ao proprietário de terras é estruturante da sociedade brasileira. Raymundo Faoro, em seu livro Os donos do poder, defende que a origem do patrimonialismo que marca a sociedade brasileira está fundada na liberdade de gerir a propriedade privada com a garantia das instituições públicas (Faoro, 2008:819). Essa característica perpassa o processo de urbanização no Brasil, em que cidades foram inicialmente locais de fechamento de negócios ligados a atividades rurais, e evoluíram transformando-se elas mesmas no próprio negócio.

Durante o processo de expansão de cidades brasileiras, ficou explicitada a associação entre poder público e empreendedores privados por meio da produção de loteamentos formais e informais. O parcelamento de terras distantes de áreas urbanizadas contou com a provisão pública de infraestrutura na direção dessas localizações, permitindo a formação de um grande estoque de terras privadas vazias à espera de valorização entre áreas limítrofes da expansão e áreas consolidadas.

Imagem 3 - Obras do monotrilho na Avenida Roberto Marinho, antiga Águas Espraiadas

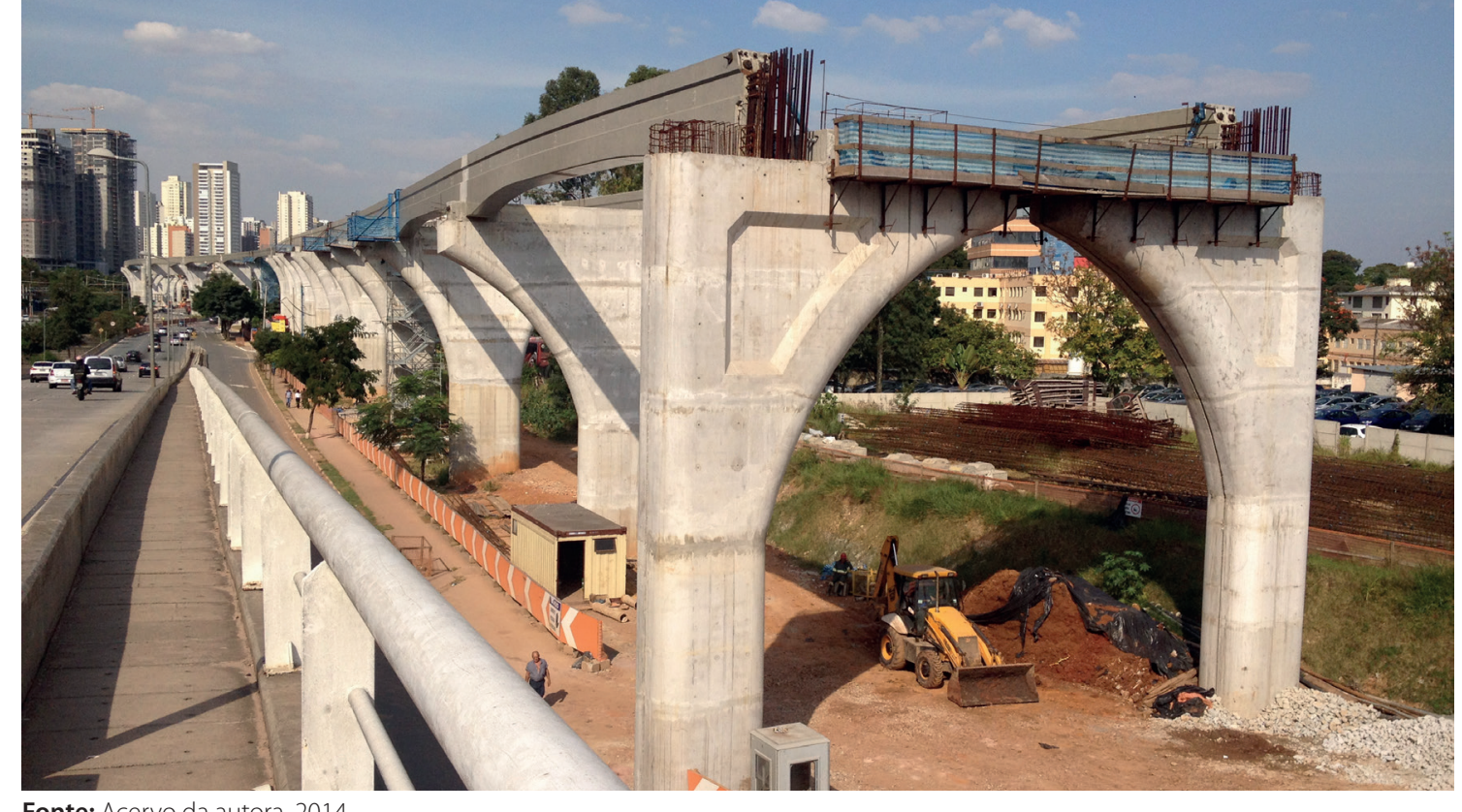

John Logan e Harvey Molotch descrevem, no livro Urban Fortunes, o processo de associação entre poder público e interesses privados no processo de desenvolvimento de algumas cidades dos Estados Unidos. Ainda que característico do capitalismo central desse país, esse processo descrito por Logan e Molotch apresenta aproximações com o capitalismo periférico na medida em que se reconhece que grupos privados determinam as direções de crescimento urbano, pressionando o poder público para que estabeleçam as condições necessárias para viabilizar seus planos de negócios. Os autores criam o termo "máquina do crescimento" para definir o contexto do desenvolvimento urbano em que

Those who make money from land and buildings have more stake in what goes on. They make more if rents and real estate prices rise. (...) Regardless of the specific quarry, they seek more demand more people needing a place to live, more retailers needing storefronts, more companies needing a location. To get all that going, they try to guide development their way. (...) To build private wealth under changing circumstances, one needs permissions, subsidies, all the right kind of public infrastructure. So along with some crucial associates that service their needs (lawyers bankers, media), the real estate interests push government levers. They use city hall, the state capital, and - insofar as they can get in to them - the halls of Congress to generate grow th for their metropolis as a whole and for their sections of it in particular. In ways we explain, the city becomes a growth machine, and its custodians are the people who grease its wheels, refurbish its parts, and tweak its direction as the needs arise. Although many - residents, tourists, manufacturers - use and have interests in the city, for one group, the city is their business. (Logan e Molotch, 2007:X)

A concentração da propriedade da terra ligada à realização de interesses do capital privado é característica marcante do processo de produção de cidades no Brasil até os dias atuais. Mesmo tendo sido a função social da propriedade definida na Constituição de 1988 e no Estatuto da Cidade, legislação de 2001, a propriedade privada da terra ainda é tratada como direito prioritário no Brasil, implicando entraves à aplicação de outros direitos fundamentais também constitucionais como o direito à moradia, entre tantos.

Sob o funcionamento do capitalismo neoliberal contemporâneo, o patrimonialismo garante a manutenção e o aprofundamento da desigualdade social e da segregação espacial por meio da restrição do acesso à terra para moradia da maioria da população, 
e também por um protagonismo dos processos de produção de espaços urbanos pelo capital financeiro.

Mariana Fix, em sua tese de doutorado, descreve o processo de financeirização do setor imobiliário no Brasil, apontando a abertura de capital das empresas imobiliárias como canal de entrada do capital estrangeiro na produção habitacional de vários segmentos, desde o de luxo ao econômico. Segundo a autora, com a concentração do capital financeiro das empresas imobiliárias e o aumento da escala da produção imobiliária habitacional, "o elemento central passa a ser o comando sobre o preço da terra e o uso do solo urbano: criação de novas fronteiras imobiliárias e de novos produtos." (Fix, 2011:222).

O principal papel da terra na produção imobiliária é servir de espaço disponível para a circulação de capital em busca de juros melhores numa competição entre investimentos. David Harvey compara os mercados de terras aos mercados de capitais, na medida em que o dinheiro pago pelo comprador da terra é equivalente a um investimento remunerado pela taxa de juros. Ressalvadas questões de risco e liquidez, ele aponta características similares entre o título de propriedade da terra e ações em bolsas de valores, o que faria da terra um "ativo financeiro puro" (Harvey, 1989:96). Ressalta ainda o papel coordenador dos proprietários fundiários na escolha seletiva de usos aplicados às suas terras com objetivo de criar condições para otimizar os lucros de seus investimentos ${ }^{4}$.

Nas cidades brasileiras, a produção de espaços urbanos é bastante orientada por interesses de proprietários de terras na reprodução do capital, resultando em uma diferenciação de localizações extremamente segregadora de populações pobres e vulneráveis.

O conceito de segregação é definido por Flavio Villaça, em seu livro Espaço intraurbano no Brasil, como "um processo segundo o qual diferentes classes ou camadas sociais tendem a se concentrar cada vez mais em diferentes regiões gerais ou conjuntos de bairros da metrópole". (Villaça, 2001:142)
Sob a lógica capitalista em que a terra funciona essencialmente como espaço disponível para receber o capital circulante em busca de rendimentos ${ }^{5}$ maiores em relação ao mercado, as melhores localizações são destinadas a produtos imobiliários mais lucrativos, e usos que não proporcionam altos lucros, como habitação de interesse social, são indesejados em determinadas localizações.

O monopólio fundiário permite que localizações apropriadas para o investimento do capital imobiliário sejam produzidas na medida e no momento do interesse do capital. Recursos públicos aplicados em urbanização, infraestrutura, equipamentos e serviços púbicos avançam abrindo caminho para o capital imobiliário privado, e reinvestimentos em áreas já bem servidas da urbanização básica são feitos para manter o crescimento bem azeitado nas localizações preferidas pelo capital imobiliário, numa valorização crescente.

\section{2 - O padrão segregador da produção habitacional no município de São Paulo}

Durante as etapas de expansão e consolidação da aglomeração urbana de São Paulo, diversas formas de acesso à terra viabilizaram a constituição de bases para a produção habitacional destinada a camadas de população de baixas rendas. O loteamento de terras distantes das áreas de urbanização consolidada, de forma oficial ou irregular, e a ocupação ilegal de terras por favelas foram as principais formas como a produção habitacional de chamado interesse social se apropriou de terras durante esse processo.

O loteamento de terras privadas distantes de áreas então urbanizadas foi amplamente praticado por empreendedores privados já a partir da década de 1930, logo após a decisão estatal pelo fim do contrato com o sistema de transporte por bondes, em 1927, que marca o início do monopólio rodoviarista em São Paulo ${ }^{6}$ e teve seu auge nas décadas

5. Ver Harvey, 2006

6. Para entender a negociaçăo que levou à não renovação de contratos de bondes, e iníicio da expansão do sistema de transporte por ônibus, ver Mautner, 1991 
de 1960 e 1970, quando o crescimento populacional alcançou taxas de 5,58\% e 7,01\% ao $\mathrm{ano}^{7}$, respectivamente.

Mapa 2 - Evolução da mancha urbana na área metropolitana de São Paulo 1881-2000

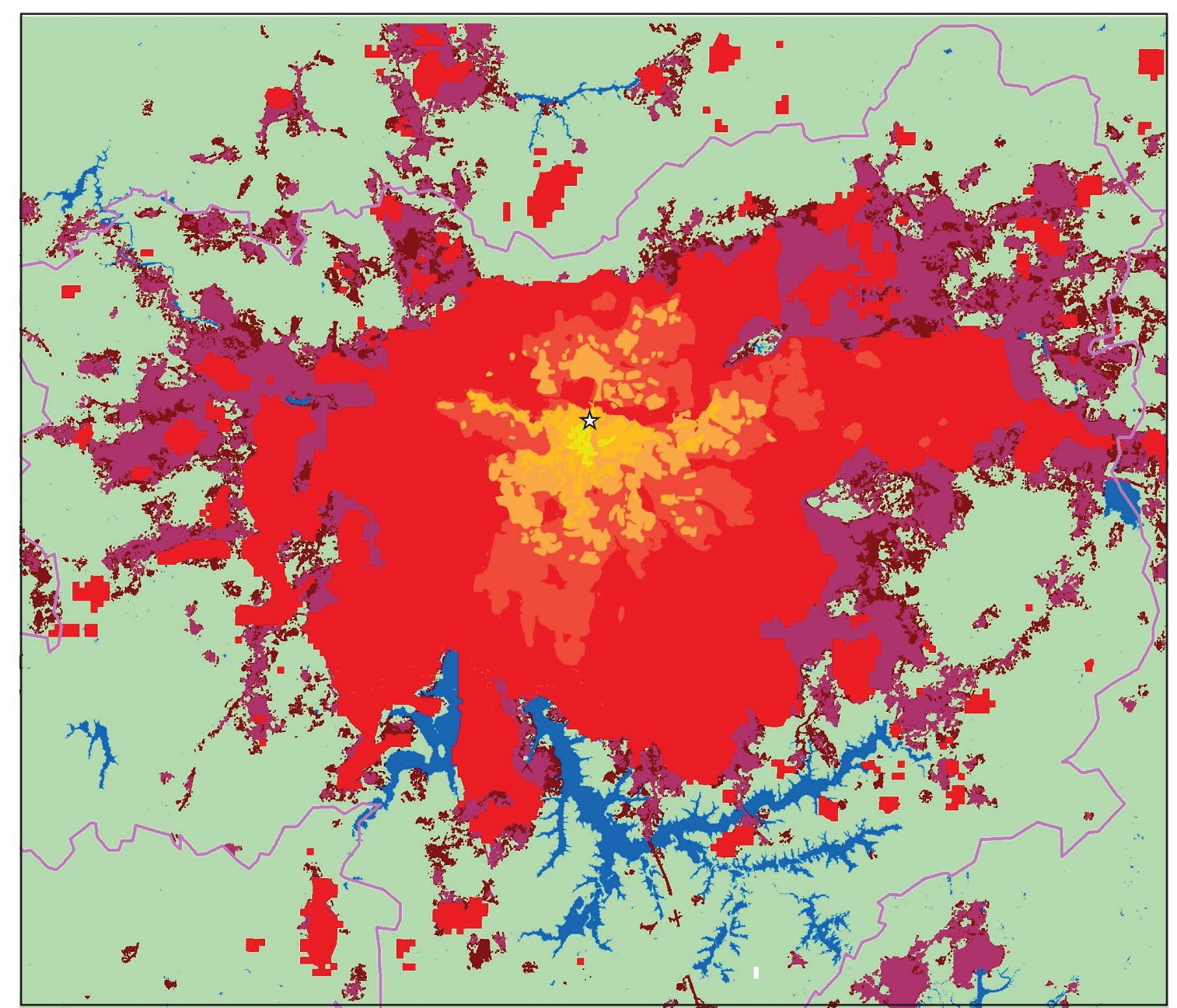

LEGENDA

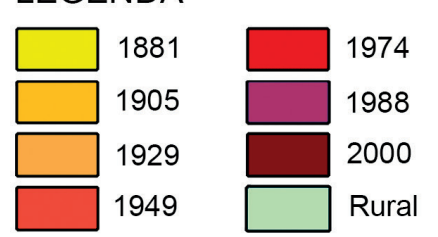

Fonte: htrp.//wmwlincolninstedu/subcenters/atlas-urban-expansion/

O negócio consistia essencialmente na compra de grandes glebas em perímetro urbano ou rural, a extensão do arruamento de acesso à área, a negociação da implantação de uma linha de ônibus ligando a cidade existente a essa nova área de expansão, o arruamento e loteamento dessa gleba, a construção de um local de apoio para a comercialização de lotes (geralmente uma padaria em frente a um ponto de ônibus), e a venda à prazo dos lotes no mercado oficial ou extraoficial ${ }^{8}$. (Sampaio, 1994).

Imagem 4 - Concentração de pessoas aguardando ônibus em Osasco, provavelmente na década de 1960

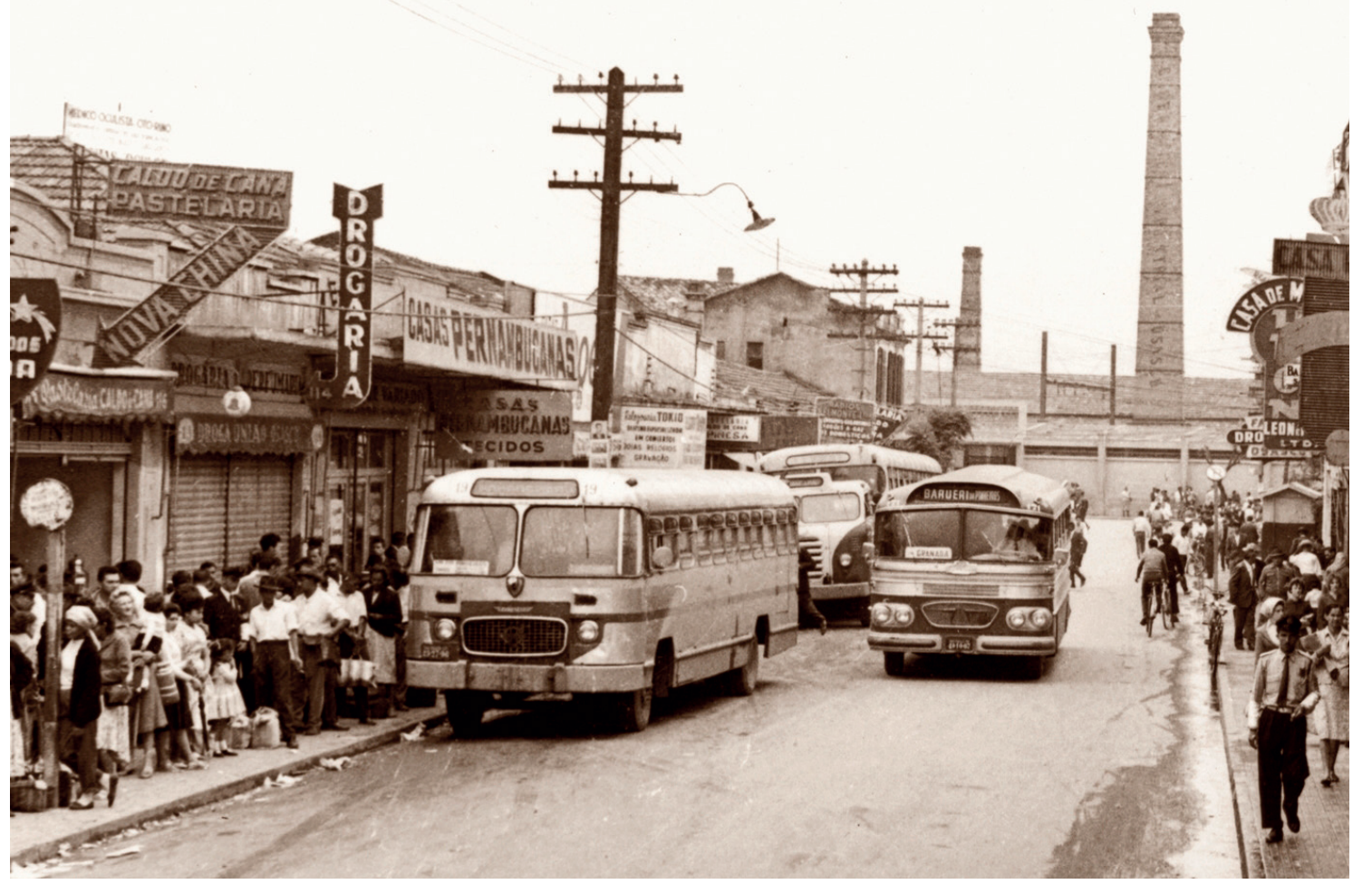

Fonte: http://hagopgaragem.com/osasco/galeria1/rua_antonio_agu/rua_agu_24_GR.jpg

A localização de terras transformadas em loteamentos urbanos (ainda que não devidamente urbanizados ou mesmo legalizados) definia o preço de compra da terra e consequentemente a taxa de lucro do negócio. O preço de venda dos lotes era muito semelhante nas diversas novas periferias, visto que se adequava à renda da demanda operária que tinha os salários também bastante nivelados. Assim, quanto mais distante da área urbana consolidada, maior o lucro não somente no negócio imediato da venda de lotes como também nos negócios futuros com terras ainda não loteadas entre a área urbana consolidada e essa nova periferia recém estabelecida. 
Imagem 5 - Loteamento da Vila Matilde, em 1963

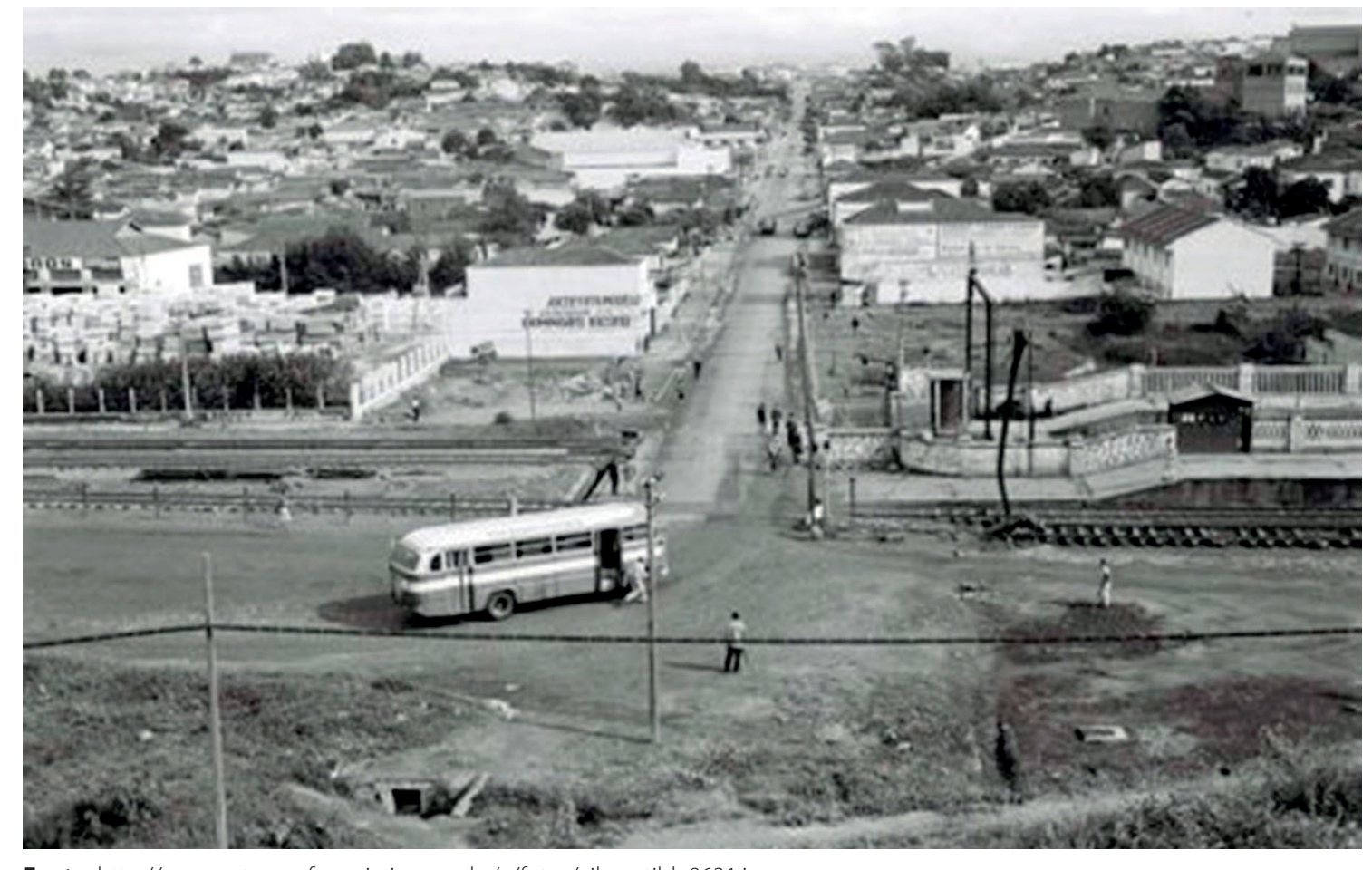

Fonte: http://www.estacoesferroviarias.com.br///fotos/vilamatilde9631.jpg

Quaisquer que sejam as formas de aquisição dos lotes: oficiais, irregulares, clandestinos ou terras invadidas, a auto-urbanização e a autoconstrução fomentaram empresas bastante lucrativas para empreendedores privados. Lojas de materiais de construção foram um ótimo negócio, mas o maior e mais lucrativo deles foi sem dúvida o parcelamento e venda da terra.

A transformação de grandes glebas (compradas muitas vezes por preços de terras rurais) em pequenos lotes urbanos (vendidas a uma enorme demanda de trabalhadores operários recém chegados do campo à cidade) foi a principal fonte de lucros de empreendedores privados durante a expansão periférica paulistana. A grande massa do operariado, à margem do mercado formal habitacional, investia grande parte de seus baixos salários na compra de lotes pagos a prazo e na paulatina autoconstrução de moradias no seu tempo de descanso. Francisco de Oliveira apontou em seus estudos que

uma não-insignificante porcentagem das residências das classes trabalhadoras foi construida pelos próprios proprietários, utilizando dias de folga e fins de semana. Ora, a habitação, bem resultante desta operação, se produz por trabalho não pago, isto é, supertrabalho. Embora aparentemente esse bem não seja desapropriado pelo setor privado da produção, ele contribui para aumentar a taxa de exploração da força de trabalho, pois o seu resultado - a casa - reflete-se numa baixa aparente do custo de reprodução da força de trabalho - de que os gastos com habitação são um componente importante - e para deprimir os salários reais pagos pelas empresas. (Oliveira, 2003:59)

Imagens 6 e 7 - Autoconstrução em terrenos oriundos de regularização fundiária em Taboão da Serra

A terra é insumo fundamental para a produção habitacional. Sem dinheiro, crédito ou financiamento se produz habitação, sem terra não. Ocupações de terras públicas e privadas configurando favelas é um dos principais modos de produção habitacional para camadas de baixos rendimentos no mundo, no Brasil e também em São Paulo

Mike Davis , em seu livro Planeta Favela, apresenta dados levantados pela ONU-Habitat sobre a população de favelas no mundo:

Os favelados, embora sejam apenas 6\% da população urbana dos paises desenvolvidos, constituem espantosos 78,2\% dos habitantes urbanos dos países menos desenvolvidos; isso corresponde a pelo menos um terço da população urbana global. (Davis, 2006:34)

No Brasil, de acordo com o Censo realizado pelo IBGE em 2010, a população moradora de aglomerados subnormais é de 11,2 milhões de habitantes, o equivalente a 6\% da população total brasileira, e no município de São Paulo são 2,7 milhões de moradores de favelas, ou aproximadamente 7\% da população total do município (IBGE, 2010).

A fragilidade legal da posse dos loteamentos irregulares e clandestinos que se alastraram pelas periferias nas décadas de 1960 e 1970, assim como o estabelecimento de relações clientelistas com o poder público municipal na busca de melhoramentos urbanos construíram um quadro de insegurança e precariedade que contribuiu para o desenho do padrão de moradia de grande parcela da população da área Metropolitana de São Paulo.

A partir da vigência da lei $n^{\circ} 6766 / 79$, a oferta de novos loteamentos diminuiu, o que, somado à crise dos anos 1980, levou à diminuição do estoque de terras baratas para expansão, implicando, nas palavras de Yvonne Mautner, uma

diminuição drástica do número de lançamentos de loteamentos na periferia de São Paulo, trazendo à tona três processos diferentes e simultâneos: aumento da densidade de loteamentos existentes, início da substituição dos moradores de baixa renda por pessoas pertencentes à classe de maior poder aquisitivo, e com a falta de lotes acessiveis, o crescimento de invasões de terra pela população de baixa renda, algumas delas altamente organizadas. (Mautner, 1991: 121)
Esse período é configurado por um grande aumento do número de favelas e da população favelada no Município de São Paulo', e também pelo adensamento das periferias, com a construção de casas de fundo e de lajes, que criaram lugar para novas moradias. A autoconstrução é a forma de produção habitacional dominante na área Metropolitana de São Paulo, e as modalidades de posse da terra definem os principais padrões de urbanização: os loteamentos irregulares ou clandestinos e as favelas.

No período entre a extinção do BNH, em 1986, e o grande crescimento na oferta de crédito habitacional a partir de meados dos anos de 2000, o financiamento para as camadas de baixas rendas da população foi muito pequeno. A construção de habitaçães populares foi basicamente configurada nesse período por conjuntos habitacionais públicos, ocupações irregulares de terras e autoconstrução.

Com o crescimento na oferta de crédito e salto da produção imobiliária residencial formal a partir dos anos de 2000, a extrema desigualdade de distribuição da rede de in fraestrutura e serviços das cidades brasileiras imprime uma tendência de encarecimento de boas localizações e de disputa acirrada por essas terras.

O acesso à terra é apontado como a principal dificuldade para a produção de habitação de interesse social, seja pelo alto preço, seja pela escassez de terrenos em localizações servidas de infraestrutura, serviços e empregos. Empreendedores privados argumentam que não há disponibilidade de terras com preço "adequado" ao atendimento da demanda com menores rendimentos. Promotores públicos apontam a inexistência de estoque de terrenos públicos, e também os altos valores definidos em processos judiciais de desapropriação de terras.

A localização residencial é uma chave fundamental para a diminuição da segregação socioterritorial. Faltam terras para a produção habitacional ou faltam boas localizações? 
Dinâmica territorial da produção imobiliária residencial no município de São Paulo na década de 2000 
Neste capítulo buscamos revelar padrões de localização de terrenos utilizados na produção imobiliária recente, especialmente a de habitação de interesse social e de mercado popular. Para isso, estudaremos dados sobre usos do solo urbano e produção imobiliária residencial no município de São Paulo entre 2000 e 2010, período em que a produção passou de 471 empreendimentos habitacionais lançados em 2000 para 671, em 2010, num crescimento de $42 \%$ no número de empreendimentos lançados por ano.

Gráfico 5 - Empreendimentos residenciais lançados por ano no municipio de São Paulo de 2000 a 2010

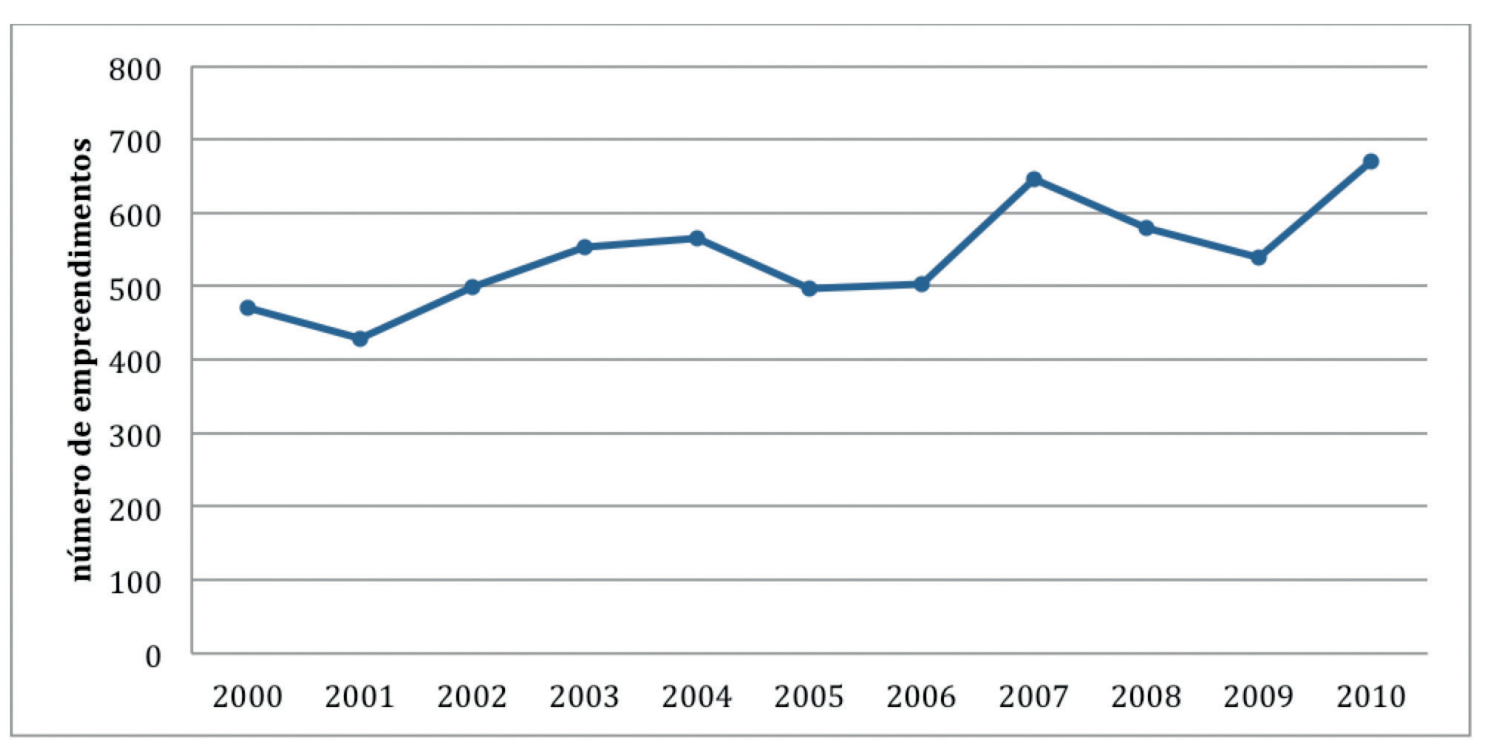

Fonte: Embraesp/CEM, dados obtidos no site http://www.fflch.usp.br//centrodametropole em setembro de 2014. Elaboraçāo da autora

O número de unidades habitacionais lançadas no município de São Paulo foi 70\% maior em 2010 que em 2000, passando de 22.026 a 37.462 unidades.
Gráfico 6 - Unidades habitacionais lançadas por ano de 2000 a 2010

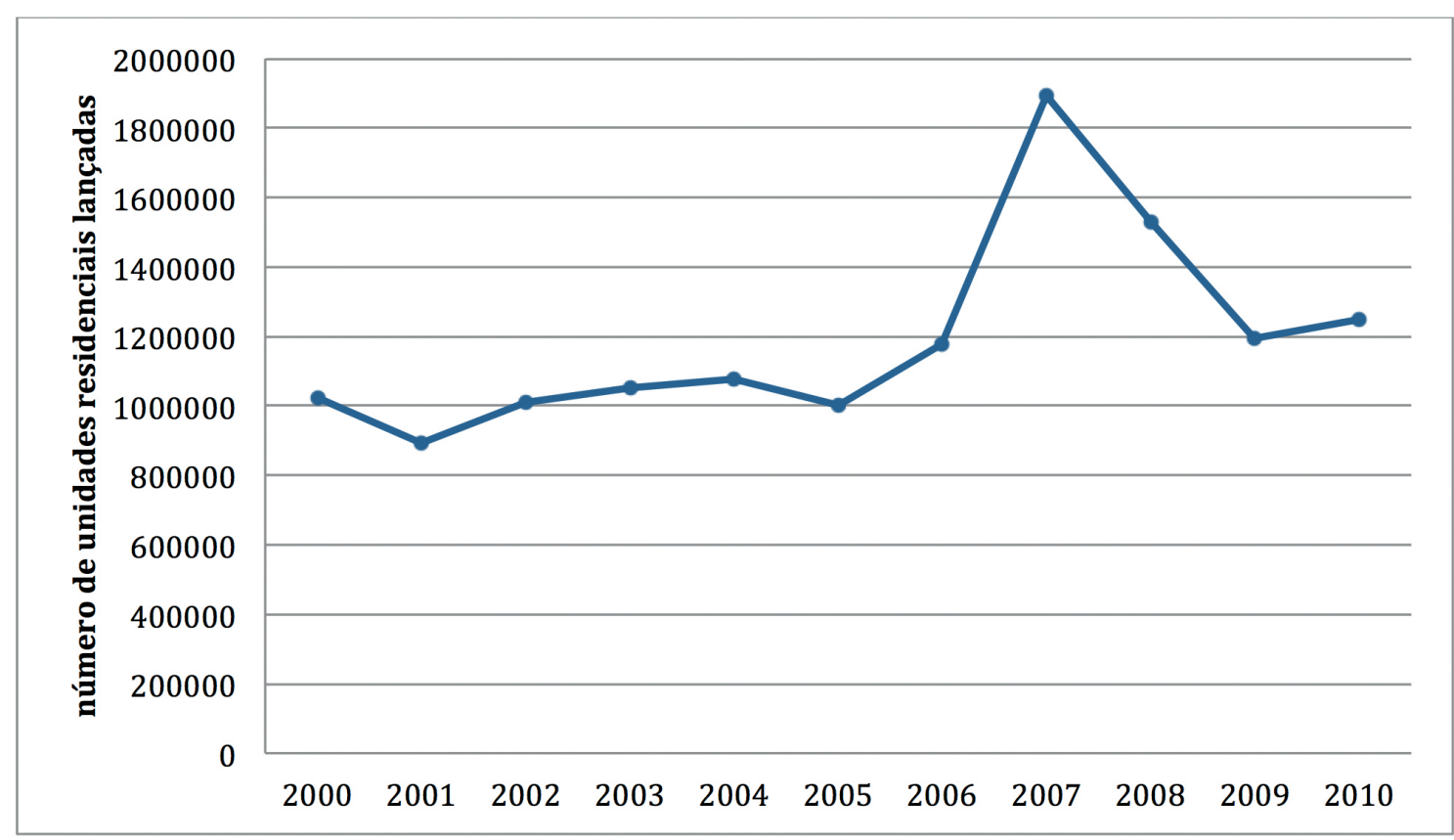

Fonte: Embraesp/CEM, dados obtidos no site http://www.fflch.usp.br//centrodametropole em setembro de 2014. Elaboraçăo da autora

A quantidade de terrenos consumidos para essa produção passou de $1.011 .140 \mathrm{~m}^{2} \mathrm{em}$ 2000 a $1.175 .499 \mathrm{~m}^{2}$ em 2010, o que representa um aumento de $16 \%$.

Gráfico 7 - Área de terrenos consumidos por ano na produção habitacional de 2000 a 2010

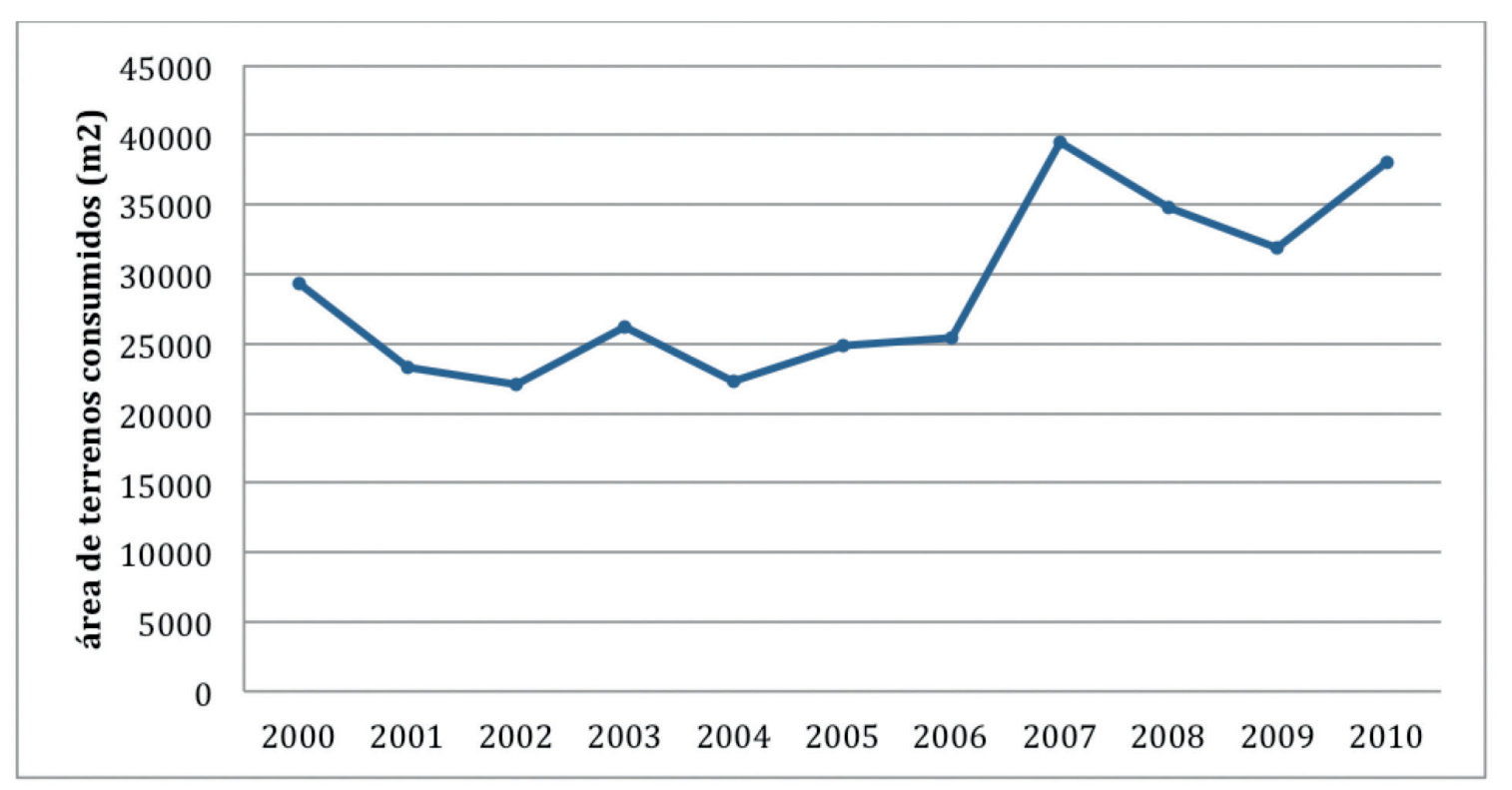

Fonte: Embraesp/CEM, dados obtidos no site http://Wwwwfflch.usp.br//entrodametropole em setembro de 2014. Elaboraçăo da autora 
Em 2007 houve um pico de produção imobiliária residencial no município de São Paulo, tanto em número de lançamentos, como de unidades produzidas e área de terreno consumidos nessa produção.

Com o objetivo de analisar a produção entre 2000 e 2010, utilizaremos valores do Programa Minha Casa Minha Vida como referência, e nomearemos os empreendimentos cuja unidade é vendida a no máximo $\mathrm{R} \$ 190.000^{1}$ - teto do valor de comercialização da unidade habitacional pelo PMCMV no município de São Paulo², de empreendimentos de interesse social e de mercado popular, agregando dois segmentos da política habitacional conforme definido pelo Plano Diretor do município ${ }^{3}$.

Entre 2000 e 2010, o lançamento de empreendimentos de interesse social e de mercado popular seguiu uma curva que variou em torno de $20 \%$ do total de empreendimentos residenciais lançados entre 2000 e 2010. Em 2000, foram 71 empreendimentos de interesse social e de mercado popular, o equivalente a $15 \%$ de um total de 534 empreendimentos residenciais lançados. Em 2007, ano de pico do número de lançamentos imobiliários na década de 2000, foram lançados 121 empreendimentos de interesse social e de mercado popular, 19,42\% do total de lançamentos residenciais, que foi de 744 empreendimentos. Em 2010, o número total de empreendimentos residenciais lançados foi de 708, dentre os quais, 9,60\%, ou 62 empreendimentos são de interesse social e de mercado popular.

1. De acordo com o $\S 10$ do Art. 20 da Resolução 702 do Conselho Curador do FGTS, de 4 de outubro de 2012, que

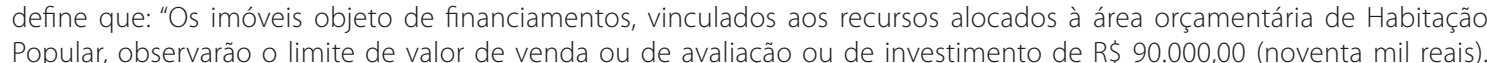
\$ 10 Admititi-se-áa a elevaçăo do limite estabelecido no caput deste artigo, nos casos a seguir especificados em municíios inte-

2. Valores de lançamento entre 2000 e 2010 atualizados pelo IGP-Dl até janeiro de 2014.

3. O Plano Diretor Estratégico do municííio de São Paulo (Lei 16.650/2014, Quadro 1 ) define como produção habitacional de interesse social aquela destinada ao atendimento habitacional das familias de baixa renda, podendo ser de a) HIS 1: destinada a famílias com renda familiar mensal de até $R \$ 2.172,00$ ou renda per capita de até $R$ \$ 362,00 ; b) HIS 2: destinada a familias com renda familiar mensal superior a $R \$ 2.172,00$ ou 362,00 per capita e igual ou inferior a $R \$$ 4.344,00 ou R\$ 724,00 per capita; e como produção habitacional de mercado popular - HMP, aquela destinada ao atendimento habitacional de familias cuja renda mensal seja superior a R\$ 4.344,00 e igual ou inferior a R\$7.240,00 com até dois há uma segmentaça em faixas de atendimento por rendimento familiar mensal. A faixa 1 atende famílias com rendimentos de até $R \$ 1$ 1600,00; a faixa 2 no limite de $R \$ 3.10000$ : na faixa 3 inserem-se familias com rendimentos até $B 55000.00$.
Gráfico 8 - Empreendimentos com valor de venda até $\mathrm{R} \$ 190.000,00$ em relação ao total de empreendimentos residenciais lançados de 2000 a 2010

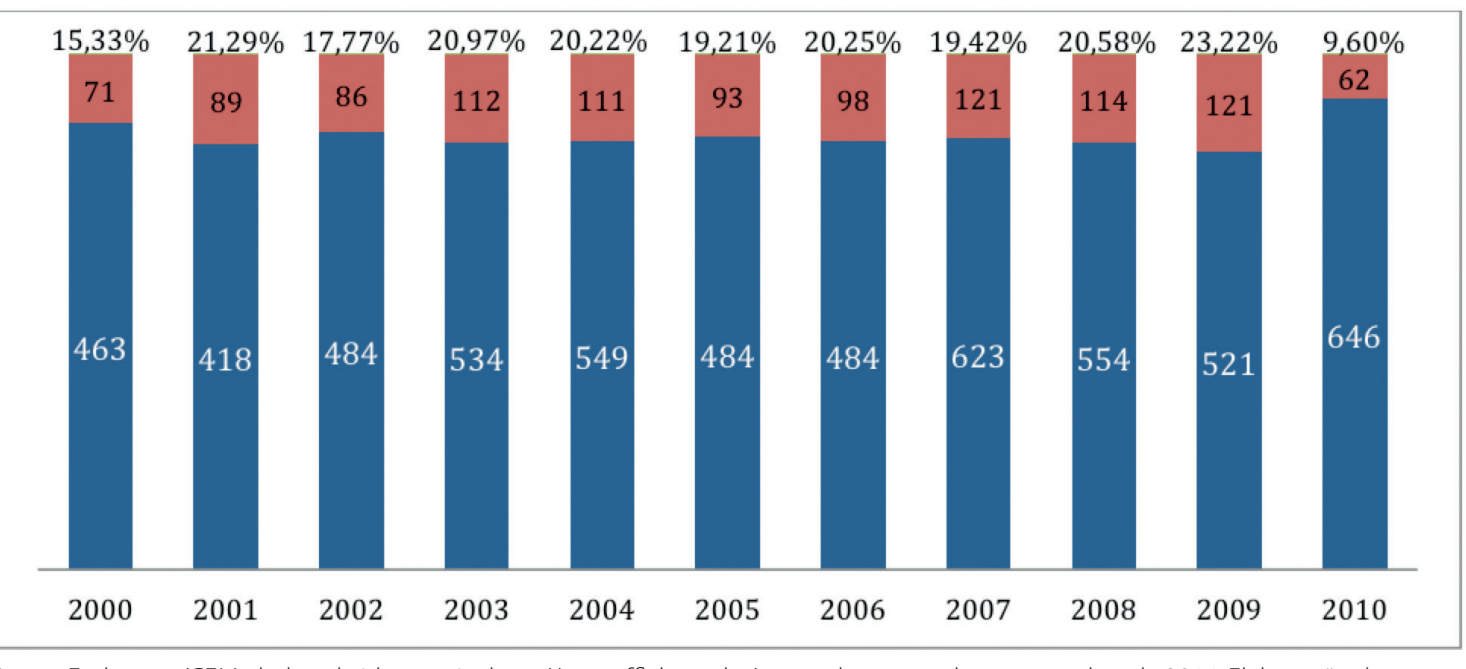

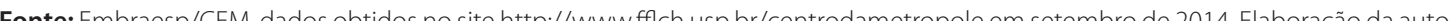

A queda no número de empreendimentos de interesse social e de mercado popular lançados em 2010 reflete o tempo de ajuste ao início da operação do programa Minha Casa Minha Vida, que, considerando o prazo de produção dos empreendimentos de dois a três anos, começou a dar resultados em 2012. A tabela a seguir mostra o número de empreendimentos e unidades habitacionais contratadas por meio do Programa Minha Casa Minha Vida entre 2009 e 2012, por faixa de atendimento.

Tabela 4 - Empreendimentos e unidades habitacionais contratados pelo Programa Minha Casa Minha Vida entre 2009 e 2012

\begin{tabular}{lcc}
\hline & Número de empreendimentos & Número de UH \\
\hline Faixa 1 & 49 & 8.848 \\
\hline Faixa 2 & 85 & 13.743 \\
\hline Faixa 3 & 82 & 14.195 \\
\hline TOTAL & $\mathbf{2 1 6}$ & $\mathbf{3 6 . 7 8 6}$ \\
\hline
\end{tabular}

Fonte: LabCidade FAUUSP 2014 
Entre 2009 e 2012, foram 216 os empreendimentos que tiveram assinatura de contrato pelo programa Minha Casa Minha Vida no município de São Paulo, 42\% do total na Região Metropolitana, que foi de 516 empreendimentos. Nesses quatro anos, a média de empreendimentos contratados pelo Programa Minha Casa Minha Vida no município de São Paulo foi de 54 por ano, num total de aproximadamente 9.200 unidades habitacionais por ano

\section{1 - Produção imobiliária por categorias de uso}

De acordo com dados do Cadastro Territorial Predial de Conservação e Limpeza do município de São Paulo - TPCL ${ }^{4}$, as tipologias de uso que mais ampliaram sua ocupação no território entre os anos de 2000 e 2013 foram as residenciais verticais de alto, médio e baixo padrão, nesta ordem.

O território ocupado por empreendimentos residenciais verticais de alto padrão foi ampliado em 4,4 milhões de metros quadrados, num crescimento de 66\% entre 2000 e 2013. A tipologia residencial vertical de médio padrão ampliou a área de terrenos ocupada em aproximadamente 4 milhões de metros quadrados, um incremento de $28 \%$. Já o território ocupado pelos usos residenciais de baixo padrão cresceu 3,6 milhões de metros quadrados. Dentre todos as tipologias de usos urbanos, a residencial vertical de baixo padrão foi a que mais ampliou proporcionalmente sua presença no território no município, sendo 70\% maior a superfície de terras ocupadas em 2013 em relação a 2000.

4. De acordo com informaçōes da Prefeitura do Município de São Paulo, o Cadastro Territorial e Predial, de Conservação e Limpeza (TPCL) "e mantido pelo Departamento de Arrecadaçąao e Cobrança (DECAR) da Secretaria Municipal de Finanç̧as Incamento e a cobranca do Imposto Predial e Territorial Urbano (IPTU) sobre a propriedade imobiliária Apesar do enfitir o predominantemente tributário no registro das informacōes, o TPCL oferece uma enorme riqueza de dados sobre uso e ocupaçâa do solo no município, sendo utilizado com frequêencia por urbanistas e planejadores como fonte para análise do espaço urbano. Com essa finalidade, a entäo Secretaria Municipal de Planejamento (Sempla) hoje Secretaria Municipal de Desenvolvimento Urbano (SMDU) estabeleceu uma metodologia de agregaçăo resultante do cruzamento entre os valores USO e PADRAO atribuidos pelo TPCL, para cada imóvel cadastrado, gerando as 16 tipologias de uso $\mathrm{H}$ relacionadas na

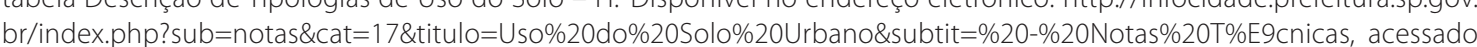
em 14.01.2015
A área construída da tipologia residencial vertical de baixo padrão teve o maior incremento percentual entre todas as tipologias avaliadas, aproximadamente $80 \%$, apesar de o aumento nominal de área construída ter sido maior para a tipologia de usos residen ciais verticais de alto padrão.

Os empreendimentos residenciais verticais de baixo padrão ocupam muito mais área de terreno em relação à área construída que os de alto e médio padrão, principalmente por acomodarem no pavimento térreo as garagens e muitas vezes apresentarem baixo gabarito para evitar a implantação de elevadores. A relação entre ampliação da área construída e da área de terreno ocupada entre 2000 e 2013 indica que os empreendimentos residenciais verticais de alto e médio padrão produzidos nesse período apresentaram coeficiente de aproveitamento médio de 5,4, enquanto que para os residenciais verticais de baixo padrão esse coeficiente ficou em 1,5.

Tabela 5 - Variação de área de terreno ocupada, área construída e número de lotes po tipologias de usos entre 2000 e 2013 no município de São Paulo

\begin{tabular}{lcccccc}
\hline Tipologias de uso & \multicolumn{2}{c}{ Área de Terreno } & \multicolumn{2}{c}{ Área Construída } & \multicolumn{2}{c}{ Número de Lotes } \\
\hline & $\mathbf{m}^{2}$ & $\%$ & $\mathbf{m}^{2}$ & $\%$ & unidades & $\%$ \\
\hline Uso Residencial Vertical Alto Padrão & 4.389 .023 & $65,79 \%$ & 23.810 .568 & $68,23 \%$ & 102.100 & $66,08 \%$ \\
\hline Uso Residencial Vertical Médio Padrão & 3.989 .486 & $27,97 \%$ & 21.574 .878 & $36,75 \%$ & 212.548 & $35,49 \%$ \\
\hline Uso Residencial Vertical Baixo Padrão & 3.575 .176 & $70,42 \%$ & 5.272 .240 & $79,80 \%$ & 73.508 & $71,49 \%$ \\
\hline Uso Coletivo ( Cinema, Clube, Templo etc) & 2.946 .845 & $14,03 \%$ & 2.845 .357 & $43,54 \%$ & 1.453 & $18,14 \%$ \\
\hline Uso Comércio e Serviço Vertical & 2.755 .660 & $24,80 \%$ & 10.660 .624 & $33,23 \%$ & 49.574 & $43,74 \%$ \\
\hline Outros usos ( Uso e padrão não previsto) & 2.192 .045 & $44,32 \%$ & 2.168 .813 & $59,74 \%$ & 6.915 & $53,02 \%$ \\
\hline Uso Escola & 1.041 .879 & $6,12 \%$ & 2.321 .840 & $32,51 \%$ & -94 & $-1,41 \%$ \\
\hline Uso Residencial Horizontal Baixo Padrão & 762.467 & $0,65 \%$ & 4.665 .040 & $9,68 \%$ & 31.015 & $5,50 \%$ \\
\hline Uso Garagens não-residenciais & 633.492 & $31,20 \%$ & 297.712 & $33,70 \%$ & 2.349 & $23,63 \%$ \\
\hline Uso Especial ( Hotel, Hospital, Cartório etc) & 443.985 & $1,69 \%$ & 3.473 .690 & $42,73 \%$ & 24.120 & $517,93 \%$ \\
\hline Uso Residencial Horizontal Médio Padrão & 179.219 & $0,16 \%$ & 6.110 .169 & $7,81 \%$ & 36.760 & $6,99 \%$ \\
\hline Uso Armazéns e Depósitos & 173.752 & $1,37 \%$ & 814.357 & $12,28 \%$ & 464 & $6,43 \%$ \\
\hline Uso Residencial Horizontal Alto Padrão & -96.776 & $-0,34 \%$ & 1.696 .073 & $10,19 \%$ & 3.533 & $7,19 \%$ \\
\hline Uso Comércio e Serviço Horizontal & -296.923 & $-0,37 \%$ & 5.764 .183 & $10,57 \%$ & 5.778 & $2,67 \%$ \\
\hline Uso Industrial & -7.167 .407 & $-20,61 \%$ & -4.221 .462 & $-18,80 \%$ & -1.551 & $-10,54 \%$ \\
\hline Terrenos Vagos & -22.092 .704 & $-21,23 \%$ & - & - & -30.521 & $-21,44 \%$ \\
\hline
\end{tabular}

Fonte: PMSP/SF - TPCL. Elaboração da autora com base em tabelas organizadas por SMDU/Dipro. 
Dentre os usos que sofreram diminuição de área ocupada, os terrenos vagos e usos industriais foram os que mais perderam território, seguidos com grande diferença pelos comerciais e serviços horizontais, e os residenciais horizontais de alto padrão, nesta ordem. Terrenos vagos tiveram redução da área ocupada em aproximadamente $22 \mathrm{mi}$ lhões de metros quadrados, ou de $21 \%$ entre 2000 e 2013. Os usos industriais reduziram a superfície ocupada em 7 milhões de metros quadrados, tendo perdido $20 \%$ da área ocupada nesse período. Os usos residenciais horizontais de alto padrão diminuíram muito pouco em superfície ocupada, foram 0,34\% entre 2000 e 2013, ou 100 mil m².

O boom imobiliário residencial vertical dos anos de 2000 ocupou no município de São Paulo principalmente terrenos vazios localizados em áreas periféricas, assim como lotes com usos industriais, comerciais horizontais, e residenciais de baixo gabarito com alto padrão construtivo em áreas consolidadas, como mostraremos a seguir.

Imagens 8, 9, 10 - Demolição de edifício de 8 pavimentos e stands de vendas de lançamentos ao longo do eixo do Elevado Costa e Silva

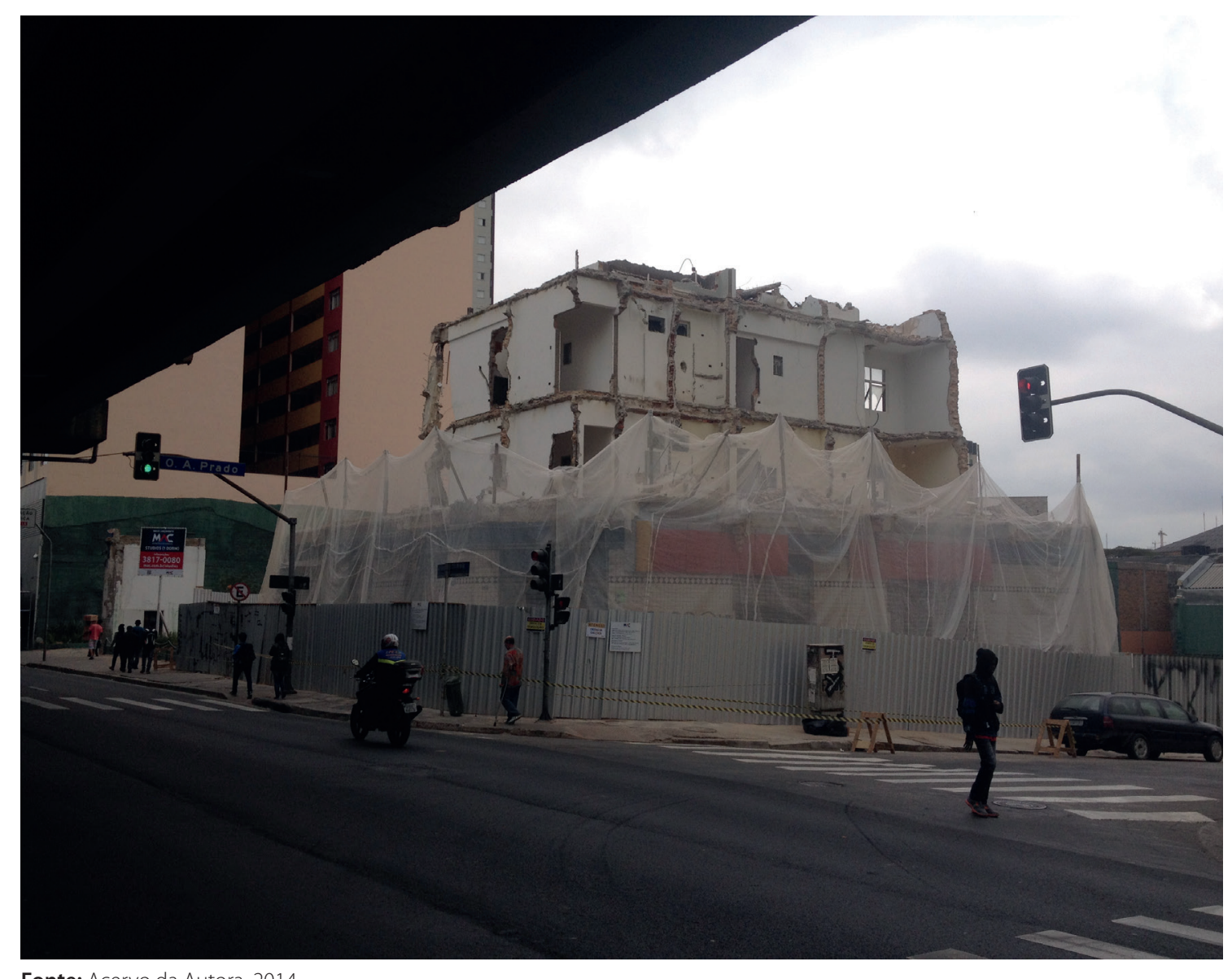

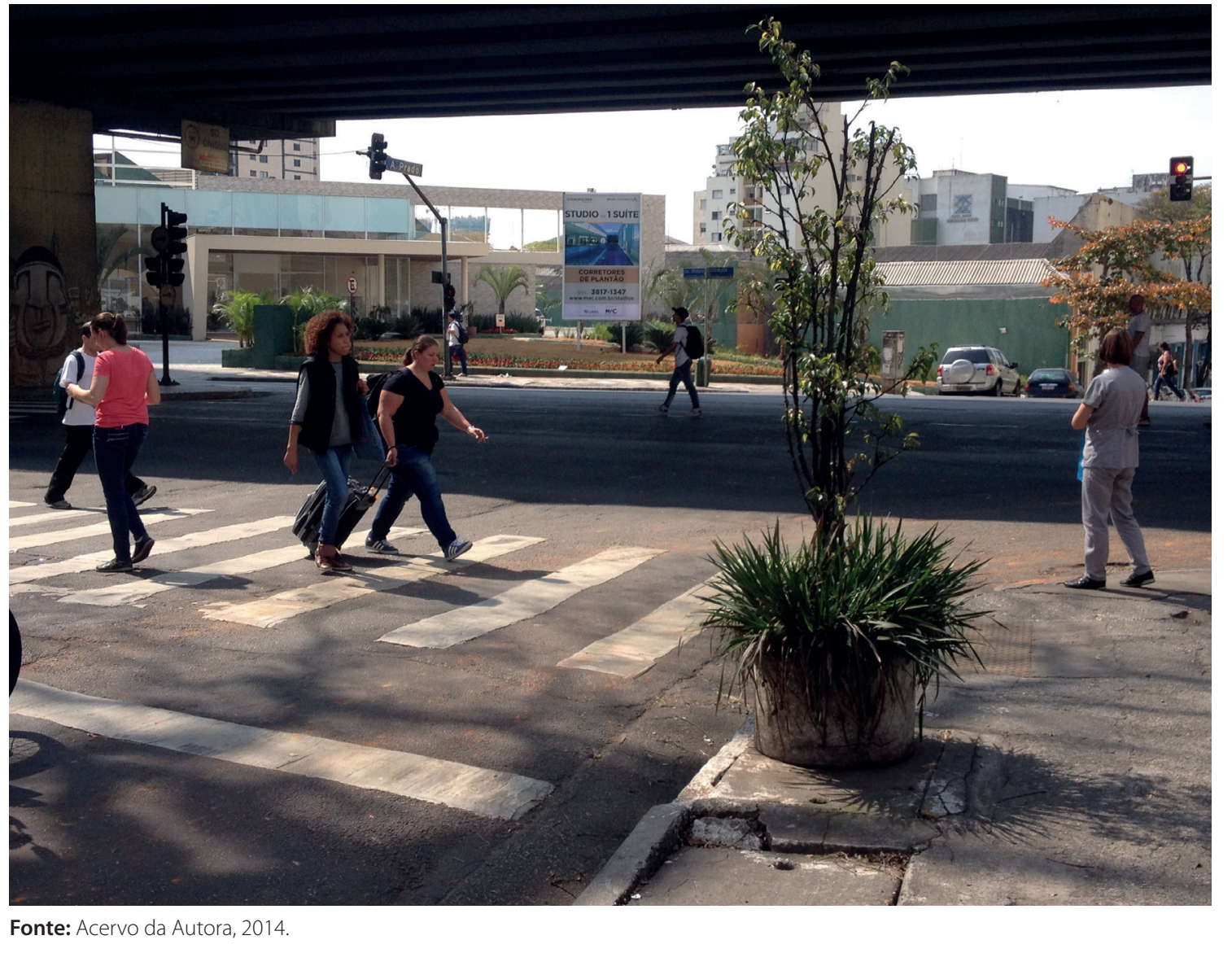

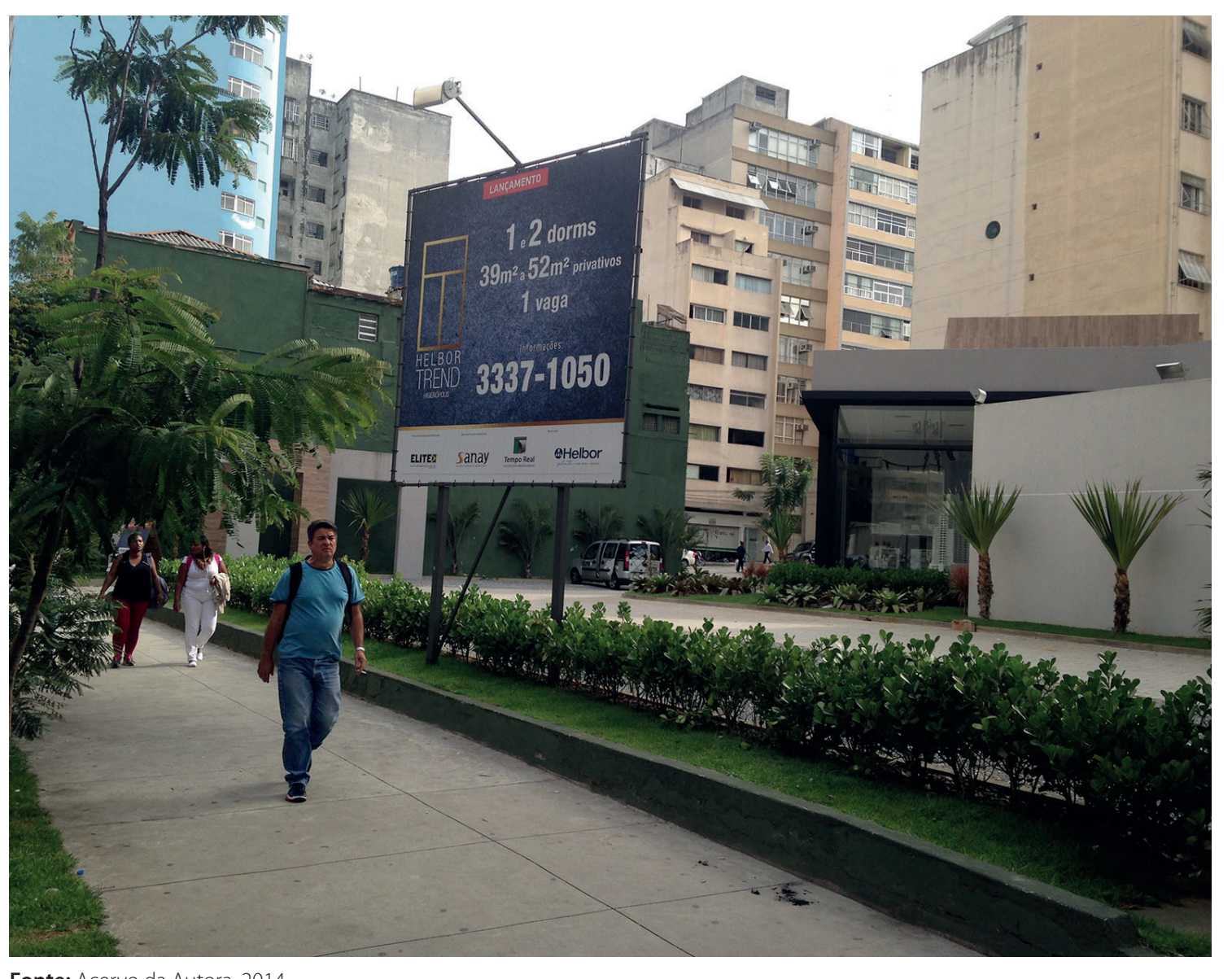


Esses números podem parecer animadores na medida em que o grande incremento na tipologia residencial vertical de baixo padrão trata da produção oficial de moradias de baixo custo, e em princípio estariam contribuindo para reduzir o déficit habitacional e a desigualdade sócio-espacial na cidade de São Paulo. Entretanto, a relação entre a ampliação de usos residenciais de baixo padrão e a redução do déficit não é direta, pois nem sempre as famílias de menor renda são as que tem acesso a esses imóveis. A oferta de habitação para as rendas mais baixas cresce muito menos que para as rendas médias. Além disso, identificar as localizações onde ocorreu essa importante expansão de terras ocupadas por usos verticais de baixo padrão na cidade de São Paulo é necessário para que se teste a hipótese de redução da desigualdade sócio-espacial. A seguir, organizamos a variação de ocupação territorial por terrenos vagos por distritos no município de São Paulo entre 2000 e 2013.

Tabela 6 - Área de terrenos vagos em 2000, 2013 e variação 2000-2013

\begin{tabular}{llll}
\hline & $\mathbf{2 0 0 0}\left(\mathbf{m}^{2}\right)$ & $\mathbf{2 0 1 3}\left(\mathbf{m}^{2}\right)$ & Variação 2000-2013 $\left(\mathbf{m}^{2}\right)$ \\
\hline Capão Redondo & 2.396 .370 & 1.098 .743 & -1.297 .627 \\
\hline Vila Andrade & 3.859 .236 & 2.701 .325 & -1.157 .911 \\
\hline Raposo Tavares & 1.686 .443 & 923.057 & -763.386 \\
\hline Grajaú & 3.852 .205 & 3.164 .223 & -687.982 \\
\hline Itaquera & 3.143 .534 & 2.483 .012 & -660.522 \\
\hline Vila Maria & 1.169 .069 & 526.000 & -643.069 \\
\hline Jabaquara & 1.367 .210 & 730.025 & -637.185 \\
\hline Rio Pequeno & 1.525 .022 & 901.800 & -623.222 \\
\hline Campo Limpo & 1.781 .403 & 1.165 .525 & -615.878 \\
\hline Morumbi & 1.793 .186 & 1.192 .804 & -600.382 \\
\hline São Mateus & 1.714 .766 & 1.115 .147 & -599.619 \\
\hline Vila Sônia & 1.801 .333 & 1.203 .275 & -598.058 \\
\hline Lajeado & 2.174 .492 & 1.580 .599 & -593.893 \\
\hline Brasilândia & 2.085 .783 & 1.520 .486 & -565.297 \\
\hline Vila Jacuí & 1.295 .047 & 753.007 & -542.040 \\
\hline São Domingos & 1.623 .873 & 1.155 .556 & -468.317 \\
\hline Cidade Líder & 2.478 .012 & 2.014 .318 & -463.694 \\
\hline Jardim São Luís & 3.715 .055 & 3.284 .769 & -430.286 \\
\hline Cursino & 1.188 .215 & 768.068 & -420.147 \\
\hline Vila Curuçá & 1.022 .016 & 618.608 & -403.408
\end{tabular}

continuação

\begin{tabular}{|c|c|c|c|}
\hline & $2000\left(m^{2}\right)$ & $2013\left(m^{2}\right)$ & Variação 2000-2013 (m²) \\
\hline Guaianases & 1.601 .213 & 1.200 .969 & -400.244 \\
\hline Artur Alvim & 899.100 & 507.088 & -392.012 \\
\hline Vila Prudente & 1.184 .226 & 837.790 & -346.436 \\
\hline Cidade Dutra & 2.481 .769 & 2.137 .977 & -343.792 \\
\hline Sacomã & 1.939 .472 & 1.598 .178 & -341.294 \\
\hline Pirituba & 1.733 .168 & 1.396.472 & -336.696 \\
\hline Itaim Bibi & 750.298 & 417.207 & -333.091 \\
\hline Jaraguá & 1.914 .781 & 1.586 .692 & -328.089 \\
\hline Penha & 847.332 & 525.550 & -321.782 \\
\hline Mandaqui & 2.158 .512 & 1.868 .378 & -290.134 \\
\hline Itaim Paulista & 1.420 .522 & 1.143 .524 & -276.998 \\
\hline São Lucas & 636.899 & 361.407 & -275.492 \\
\hline Consolação & 345.903 & 70.837 & -275.066 \\
\hline Cidade Ademar & 920.911 & 651,293 & -269.618 \\
\hline Parque do Carmo & 871.727 & 602.500 & -269.227 \\
\hline Cangaíba & 937.529 & 675.485 & -262.044 \\
\hline Freguesia do 0 . & 1.008 .773 & 780.911 & -227.862 \\
\hline Cachoeirinha & 1.040 .157 & 818.902 & -221.255 \\
\hline Tremembé & 2.088 .238 & 1.869 .865 & -218.373 \\
\hline Jardim Ângela & 4.696.326 & 4.481.901 & -214.425 \\
\hline Jardim Helena & 1.983 .817 & 1.771 .903 & -211.914 \\
\hline Ermelino Matarazzo & 1.007.427 & 804.256 & -203.171 \\
\hline Alto de Pinheiros & 663.719 & 470.333 & -193.386 \\
\hline Vila Matilde & 478.290 & 292.999 & -185.291 \\
\hline Vila Guilherme & 482.868 & 315.963 & -166.905 \\
\hline Pedreira & 3.207 .945 & 3.041 .772 & -166.173 \\
\hline Jaçanã & 384.725 & 224.538 & -160.187 \\
\hline Limão & 400.530 & 249.284 & -151.246 \\
\hline Parelheiros & 3.403 .477 & 3.254 .858 & -148.619 \\
\hline Santo Amaro & 1.070 .983 & 931.532 & -139.451 \\
\hline Ponte Rasa & 402,535 & 264.788 & -137.747 \\
\hline Vila Formosa & 479.082 & 341.392 & -137.690 \\
\hline Bela Vista & 440.145 & 308.979 & -131.166 \\
\hline Tatuapé & 471.703 & 343.419 & -128.284 \\
\hline Perus & 526.676 & 399.505 & -127.171 \\
\hline Lapa & 329.133 & 202.642 & -126.491 \\
\hline Campo Belo & 401.167 & 285.007 & -116.160 \\
\hline São Rafael & 455.282 & 341.598 & -113.684 \\
\hline Socorro & 747.438 & 635.163 & -112.275 \\
\hline
\end{tabular}

continua 
conclusão

\begin{tabular}{|c|c|c|c|}
\hline & $2000\left(m^{2}\right)$ & $2013\left(m^{2}\right)$ & Variação 2000-2013 (m²) \\
\hline Carrão & 249.992 & 139.795 & -110.197 \\
\hline Santana & 450.478 & 341.132 & -109.346 \\
\hline Barra Funda & 513.654 & 404.591 & -109.063 \\
\hline Moema & 283.030 & 182.152 & -100.878 \\
\hline Ipiranga & 511.671 & 414.427 & -97.244 \\
\hline Perdizes & 188.934 & 96.841 & -92.093 \\
\hline Vila Mariana & 357.280 & 273.962 & -83.318 \\
\hline José Bonifácio & 541.534 & 460.434 & -81.100 \\
\hline São Miguel & 482.531 & 402.692 & -79.839 \\
\hline Butantã & 431.136 & 356.499 & -74.637 \\
\hline Saúde & 276.999 & 207.115 & -69.884 \\
\hline Jardim Paulista & 133.223 & 64.842 & -68.381 \\
\hline Casa Verde & 396.993 & 328.720 & -68.273 \\
\hline Pinheiros & 354.801 & 288.312 & -66.489 \\
\hline Barra Funda & 140.862 & 75.798 & -65.064 \\
\hline Liberdade & 154.191 & 99.823 & -54.368 \\
\hline Água Rasa & 311.406 & 267.437 & -43.969 \\
\hline Santa Cecilia & 147.656 & 107.498 & -40.158 \\
\hline Belém & 93.806 & 55.247 & -38.559 \\
\hline Anhanguera & 1.283 .622 & 1.246 .879 & -36.743 \\
\hline Cambuci & 126.334 & 94.251 & -32.083 \\
\hline Bom Retiro & 99.342 & 74.947 & -24.395 \\
\hline Brás & 99.342 & 74.947 & -24.395 \\
\hline Vila Medeiros & 357.583 & 335.912 & -21.671 \\
\hline Marsilac & 1.212 .387 & 1.198.309 & -14.078 \\
\hline Jaguara & 233.535 & 222.556 & $-10,979$ \\
\hline Aricanduva & 552.610 & 543.311 & $-9,299$ \\
\hline Sé & 50.280 & 43.310 & $-6,970$ \\
\hline República & 53.430 & 50.637 & $-2,793$ \\
\hline Pari & 68.494 & 90.653 & 22,159 \\
\hline Vila Leopoldina & 449.806 & 472.418 & 22,612 \\
\hline Campo Grande & 698.309 & 724.101 & 25,792 \\
\hline Sapopemba & 2.025 .573 & 2.077 .504 & 51,931 \\
\hline Tucuruvi & 530.259 & 602.107 & 71,848 \\
\hline Moóca & 276.582 & 367.635 & 91,053 \\
\hline Jaguaré & 574.088 & 800.158 & 226,070 \\
\hline Iguatemi & 711.567 & 982.241 & 270,674 \\
\hline Cidade Tiradentes & 237.851 & 547.743 & 309,892 \\
\hline
\end{tabular}

Fonte: Prefeitura do Município de Săo Paulo, SMDU/SF, TPCL. Elaboraçăo da autora.
Mapa 3 - Ocupação por terrenos vagos entre 2000 e 2013



Variação de área $\left(\mathrm{m}^{2}\right)$ dos Lotes Vagos por Distrito
entre 2000 e 2013 - SMDU/SF TPCL

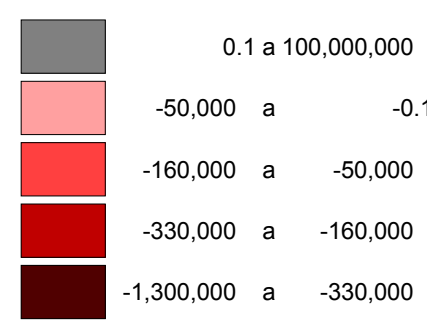

Fonte: Prefeitura do Municíio de São Paulo, SMDU/SF, TPCL. Elaboração da autora e de Edson Capitânio.

Os distritos que mais perderam área de terrenos vagos localizam-se nos limites do centro expandido assim como nas periferias mais distantes. O primeiro colocado em perda de área de terrenos vazios foi o distrito de Capão Redondo, que perdeu aproximadamente 1,3 milhões de metros quadrados de terrenos vagos entre 2000 e 2013, 54\% do total cadastrado em 2000. O segundo distrito que mais variou negativamente em área de terrenos vagos foi Vila Andrade, que reduziu o estoque de terrenos vazios em $30 \%$, tendo perdido 1,2 milhões de metros quadrados. Localizados no vetor sudoeste da cidade, os dois distritos que mais perderam terrenos vazios no período representam uma fronteira de expansão de empreendimentos tanto de alto como de baixo padrão, 
reproduzindo o modelo de segregação sócio-espacial dos vizinhos Panamby e favela de Paraisópolis. Capão Redondo foi o segundo distrito que mais ampliou a área ocupada por uso residencial vertical de baixo padrão, num incremento de $372 \%$ entre 2000 e 2013, no entanto não houve variação de área ocupada pelo alto padrão no mesmo período. Já Vila Andrade registrou um movimento reverso: houve incremento de 141\% no território ocupado por uso residencial vertical de alto padrão e nenhuma variação de área ocupada por uso residencial vertical de baixo padrão.

O terceiro e o quarto distritos que mais perderam áreas de terrenos vagos para outros usos entre 2000 e 2013 estão localizados nas periferias extremas do município. Os distritos de Raposo Tavares, no limite oeste, e o Grajaú, no limite sudeste da cidade, deram lugar a outros usos substituindo terrenos vagos em aproximadamente 760 e $690 \mathrm{mil}$ metros quadrados, respectivamente. O uso que mais cresceu em ocupação de terras no distrito de Raposo Tavares foram galpões e armazéns, aproveitando a acessibilidade às rodovias Raposo Tavares, Régis Bittencourt e Rodoanel. No Grajaú, o uso que mais ganhou terreno foi o residencial horizontal de baixo padrão, reproduzindo o padrão de crescimento periférico paulistano de décadas anteriores.

Tabela 7 - Área de terrenos ocupados por uso residencial vertical de baixo padrão em 2000, 2013 e variação 2000-2013

\begin{tabular}{lccc}
\hline Distrito & $\mathbf{2 0 0 0}$ & $\mathbf{2 0 1 3}$ & Variação 2000 - 2013 \\
\hline Cidade Tiradentes & 81.602 & 1.049 .455 & 967.853 \\
\hline Capão Redondo & 57.186 & 270.155 & 212.969 \\
\hline Campo Limpo & 117.829 & 290.584 & 172.755 \\
\hline Sapopemba & 230.685 & 387.046 & 156.361 \\
\hline Cachoeirinha & 30.876 & 152.318 & 121.442 \\
\hline Raposo Tavares & 106.605 & 223.891 & 117.286 \\
\hline Jardim São Luís & 16.537 & 112.593 & 96.056 \\
\hline Itaquera & 221.479 & 315.838 & 94.359 \\
\hline Sacomã & 232.436 & 320.013 & 87.577 \\
\hline José Bonifácio & 757.740 & 834,671 & 76.931 \\
\hline Vila Jacuí & 8.968 & 85.698 & 76.730 \\
\hline Cidade Dutra & 161.200 & 234.880 & 73.680 \\
\hline Itaim Paulista & 123.922 & 197.504 & 73.582 \\
\hline Lajeado & 5.984 & 73.645 & 67.661
\end{tabular}

Lajeado

73.645

67.661

\begin{tabular}{|c|c|c|c|}
\hline Distrito & 2000 & 2013 & Variação 2000 - 2013 \\
\hline Jaraguá & 119.938 & 185.970 & 66.032 \\
\hline Cidade Ademar & 49.652 & 112.900 & 63.248 \\
\hline Guaianases & 111.470 & 172.952 & 61.482 \\
\hline Ermelino Matarazzo & 30.068 & 76.362 & 46.294 \\
\hline Limão & 46.780 & 89.111 & 42.331 \\
\hline Artur Alvim & 526.208 & 567.700 & 41.492 \\
\hline Alto de Pinheiros & 2.521 & 42.351 & 39.830 \\
\hline Jabaquara & 19.845 & 58.258 & 38.413 \\
\hline Jardim Helena & 159 & 33.539 & 33.380 \\
\hline Moóca & 40.871 & 72.087 & 31.216 \\
\hline Campo Grande & 69.610 & 100.746 & 31.136 \\
\hline Vila Curuçá & 792 & 31.439 & 30.647 \\
\hline Cangaíba & 162.840 & 192.866 & 30.026 \\
\hline Santana & 50.040 & 79.895 & 29.855 \\
\hline Ponte Rasa & 4.138 & 33.973 & 29.835 \\
\hline Vila Prudente & 29.972 & 58.759 & 28.787 \\
\hline Vila Guilherme & 20.889 & 49.084 & 28.195 \\
\hline Parque do Carmo & 8.100 & 32.471 & 24.371 \\
\hline Mandaqui & 101.686 & 124.614 & 22.928 \\
\hline Morumbi & 1.271 & 24.066 & 22.795 \\
\hline Vila Sônia & 4.586 & 26.638 & 22.052 \\
\hline Pedreira & 27.563 & 48.114 & 20.551 \\
\hline Cidade Líder & 17.437 & 37.770 & 20.333 \\
\hline Ipiranga & 124.899 & 145.229 & 20.330 \\
\hline Brás & 6.489 & 24.636 & 18.147 \\
\hline Vila Mariana & 12.086 & 29.719 & 17.633 \\
\hline Belém & 10.282 & 26.975 & 16.693 \\
\hline São Domingos & 7.767 & 24.042 & 16.275 \\
\hline Butantã & 6.542 & 21.601 & 15.059 \\
\hline Jardim Ângela & 19.319 & 33.937 & 14.618 \\
\hline Vila Leopoldina & 3.041 & 17.169 & 14.128 \\
\hline Bom Retiro & 6.036 & 19.204 & 13.168 \\
\hline Saúde & 9.871 & 22.829 & 12.958 \\
\hline Santa Cecília & 20.380 & 32.646 & 12.266 \\
\hline Pirituba & 45.987 & 57.905 & 11.918 \\
\hline Freguesia do 0 . & 21.089 & 32.793 & 11.704 \\
\hline Penha & 4.103 & 15.296 & 11.193 \\
\hline São Miguel & 14.809 & 25.526 & 10.717 \\
\hline República & 18.708 & 28.433 & 9.725 \\
\hline Vila Andrade & 0 & 9.376 & 9.376 \\
\hline Tatuapé & 20.697 & 29.726 & 9.029 \\
\hline São Rafae & 0 & 8.928 & 8.928 \\
\hline
\end{tabular}

São Rafae 
conclusão

\begin{tabular}{|c|c|c|c|}
\hline Distrito & 2000 & 2013 & Variação 2000 - 2013 \\
\hline Aricanduva & 29.739 & 38.295 & 8.556 \\
\hline Bela Vista & 23.797 & 32.353 & 8.556 \\
\hline Liberdade & 7.175 & 15.455 & 8.280 \\
\hline Vila Maria & 29.768 & 37.710 & 7.942 \\
\hline Rio Pequeno & 25.668 & 33.418 & 7.750 \\
\hline Tucuruvi & 148.346 & 155.881 & 7.535 \\
\hline Tremembé & 3.375 & 10.410 & 7.035 \\
\hline Cambuci & 31.823 & 38.400 & 6.577 \\
\hline Socorro & 0 & 6.527 & 6.527 \\
\hline Itaim Bibi & 7.683 & 13.354 & 5.671 \\
\hline Brasilândia & 379 & 5.835 & 5.456 \\
\hline Pari & 2.643 & 7.797 & 5.154 \\
\hline Vila Matilde & 800 & 5.545 & 4.745 \\
\hline Perdizes & 13.028 & 17.165 & 4.137 \\
\hline Casa Verde & 3.217 & 7.174 & 3.957 \\
\hline Jaguaré & 45.888 & 49.792 & 3.904 \\
\hline Pinheiros & 65.771 & 69.397 & 3.626 \\
\hline São Lucas & 51.352 & 54.229 & 2.877 \\
\hline Campo Belo & 8.645 & 11.306 & 2.661 \\
\hline Sé & 6.620 & 9.137 & 2,517 \\
\hline Consolação & 5.320 & 7.828 & 2.508 \\
\hline Lapa & 57.830 & 60.235 & 2.405 \\
\hline Água Rasa & 11.783 & 13.859 & 2.076 \\
\hline São Mateus & 179.394 & 181.227 & 1.833 \\
\hline Cursino & 27.267 & 28.121 & 854 \\
\hline Carrão & 7.848 & 8.694 & 846 \\
\hline Jardim Paulista & 7.735 & 8.575 & 840 \\
\hline Moema & 2.660 & 3.331 & 671 \\
\hline Santo Amaro & 27.313 & 27.879 & 566 \\
\hline Barra Funda & 1.632 & 2.082 & 450 \\
\hline Vila Formosa & 10.217 & 10.218 & 1 \\
\hline Anhanguera & 0 & 0 & 0 \\
\hline Iguatemi & 310 & 310 & 0 \\
\hline Jaguara & 0 & 0 & 0 \\
\hline Marsilac & 0 & 0 & 0 \\
\hline Parelheiros & 0 & 0 & 0 \\
\hline Perus & 0 & 0 & 0 \\
\hline Vila Medeiros & 60.747 & 60.590 & -157 \\
\hline Jaçanã & 35.728 & 35.254 & -474 \\
\hline Grajaú & 183.732 & 178.690 & -5.042 \\
\hline
\end{tabular}

Fonte: Prefeitura do Município de Săo Paulo, SMDU/SF, TPCL. Elaboraçăo da autora.
O uso residencial vertical de baixo padrão, de acordo com dados do Cadastro Territorial Predial de Conservação e Limpeza do município de São Paulo - TPCL, ampliou em $70,42 \%$ a área de terrenos ocupados entre 2000 e 2013. Percentualmente, foi o uso que mais expandiu em área ocupada no período. Nominalmente, a área de terrenos ocupada por uso residencial vertical de baixo padrão cresceu $35.751 .176 \mathrm{~m}^{2}$, terceira maior ampliação no período, depois dos usos verticais de alto padrão e médio padrão. A localização desse crescimento notadamente nos distritos periféricos do município foi registrada no Mapa 4, a seguir.

Mapa 4 - Ocupação por uso residencial horizontal de baixo padrão entre 2000 e 2013



Variação de área de Uso Residencial Vertical de Baixo Padrão
por Distrito - entre 2000 e 2013, SMDUISF TPCL

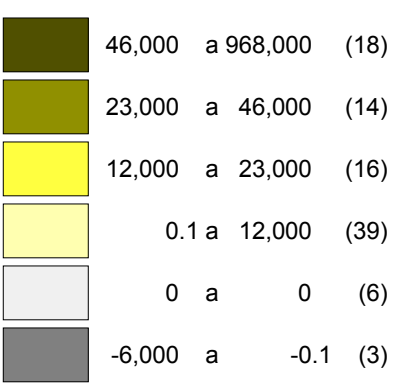

Fonte: Prefeitura do Município de São Paulo, SMDU/SF, TPCL. Elaboração da autora e de Edson Capitânio. 
Os distritos que mais ganharam área ocupada pelo uso residencial vertical de baixo padrão foram: Cidade Tiradentes, no extremo leste do município, que ampliou em 967.853 $\mathrm{m}^{2}$ a área ocupada por esse uso, num crescimento de 1.186\% em 13 anos. Esses números em Cidade Tiradentes incorporam, além da produção no período, uma ampliação relacionada ao cadastramento de usos anteriormente irregulares, o que justifica o grande crescimento dos números aferidos. Em seguida, o distrito de Capão Redondo, no extremo sudoeste do município, ganhou $212.969 \mathrm{~m}^{2}$ de área ocupada por uso residencial vertical de baixo padrão, num salto de $372 \%$ entre 2000 e 2013. Campo Limpo, também do limite sudoeste da cidade, e Sapopemba, na borda sudeste do município, ampliaram a área ocupada por uso residencial de baixo padrão em $172.755 \mathrm{~m}^{2}$ e $156.361 \mathrm{~m}^{2}$, respectivamente, tendo Campo Limpo incrementado esse uso em 146,62\%, e Sapopemba, em 67,78\%. O distrito de Cachoeirinha, no limite norte do município, o quinto que mais ampliou sua área ocupada por uso residencial vertical de baixo padrão, teve incremento de $121.442 \mathrm{~m}^{2}$, ou 393,32\% entre 2000 e 2013. Raposo Tavares, no limite oeste da cidade, ganhou 117.286 $\mathrm{m}^{2}$ de uso residencial vertical de baixo padrão entre 2000 e 2013, numa variação de 110\% no período. Do sétimo ao vigésimo colocados em incremento de área ocupada por uso residencial vertical de baixo padrão, os distritos estão, se não na borda do município, bem próximos delas. Oito deles estão localizados no extremo leste da cidade: Itaquera, José Bonifácio, Vila Jacuí, Itaim Paulista, Lajeado, Guaianases, Ermelino Matarazzo e Artur Alvim; três distritos no limite sudeste: Sacomã, Cidade Dutra e Cidade Ademar; dois no extremo norte: Jaraguá e Limão; e um distrito na borda sul, o Jardim São Luís.

\section{2 - Padrões de localização da produção de habitação de interesse social e de} mercado popular

A fim de analisar o padrão de localização da produção destinada à habitação de interesse social e de mercado popular no município de São Paulo, consideramos dados da localização por distrito dos empreendimentos residenciais produzidos pela $\mathrm{COHAB}$ -SP até 2006, da localização pontual dos empreendimentos Minha Casa Minha Vida contratados entre 2009 e 2012, e da localização pontual da produção do mercado imobiliário com preço máximo de $\mathrm{R} \$ 190.000,00^{5}$ por unidade, que é o teto do valor da unidade do Programa Minha Casa Minha Vida para o município de São Paulo ${ }^{6}$. Esses dados estão especializados no Mapa 5, a seguir.

\section{Mapa 5 - Localização de empreendimentos de habitação de interesse social} produzidos entre 2000 e 2010

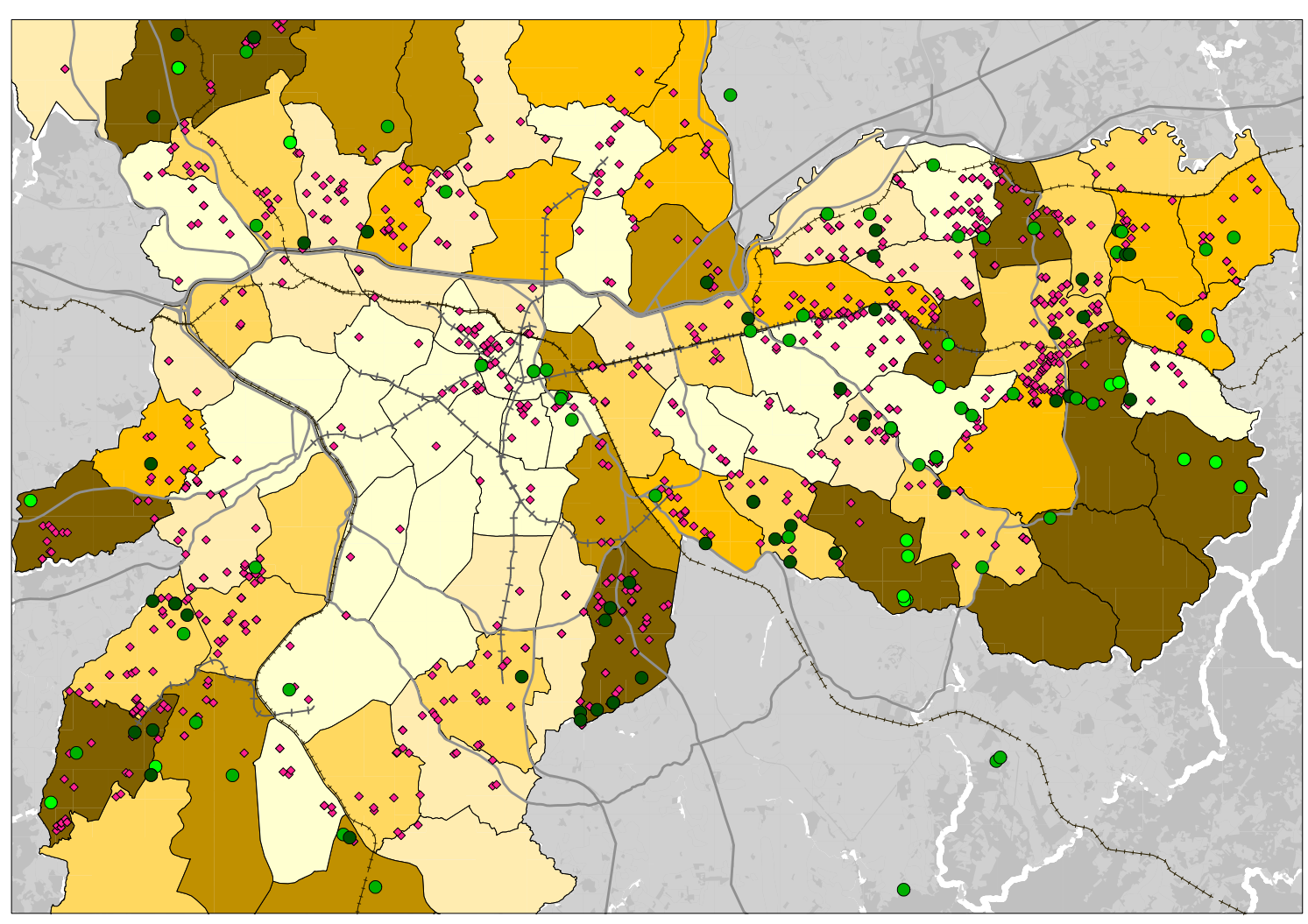

Empreendimentos imobiliários com valor de até $\mathrm{R} \$ 190.000,00$ Produção de HIS por Distrito - COHAB 2000 Lançados de 2000 até 2011 (valores atualizados até jan 2014)-CEM2013

Minha Casa Minha Vida 2014

\section{Faixa 1}

Faixa 2 Abaixo de 300 moradias 301 a 750

751 a 2000

2001 a 3000

Acima de 3001 moradias

Fonte: Embraesp/CEM 2000-2010, PMSP, LabCidade 2014. Elaboração de Edson Capitânio e da autora

6. A legislaçăo do municíio de São Paulo (PDE 2014) define como produção habitacional de interesse social a produçăo pública ou privada destinada a famililas com renda de até 3 salários minimos - HIS 1, de 3 a 6 salários minimos - HIS 2 $R \$ 1.600,00$; a faixa 2 no limite de $R \$ 3.100,00$; e na faixa 3 inserem-se familias com rendimentos até $R \$ 5.000,00$. 
Os distritos limítrofes do município de São Paulo são os que abrigam mais empreendimentos residenciais da COHAB - SP. Isso se deve à política de aquisição de terrenos praticada entre os anos de 1970 e 1990, quando o município adquiriu grandes glebas periféricas.

Para formação do estoque de terras da COHAB-SP no município de São Paulo, o aporte de recursos federais foi fundamental, principalmente após 1975, quando começou a receber recursos federais do Plano Nacional de Habitação Popular - PLANHAP. A COHAB - SP adquiriu um total de 2.898 hectares de terrenos entre 1965 e 1991, a maioria deles em grandes glebas. No final dos anos de 1990, mais de $86 \%$ das áreas de pro-

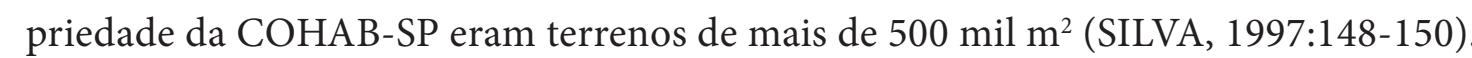

A produção habitacional de interesse social em grandes terrenos distantes de áreas urbanizadas resulta na construção de imensos conjuntos habitacionais, como o complexo Santa Etelvina, no distrito de Cidade Tiradentes, por exemplo, que soma mais de 26 mil unidades habitacionais agrupadas em sete glebas de terrenos. Esses conjuntos funcionam como cidade-dormitório e, pela falta de diversidade social configuram guetos que reproduzem pobreza urbana há pelo menos vinte anos.

Helena Menna Barreto Silva organiza, em sua tese de doutorado, um histórico detalhado da aquisição de terras pelo município de São Paulo Companhia Metropolitana de Habitação - COHAB-SP, e conclui que

A maioria das áreas foi obtida por compra, seja com recursos próprios, seja com recursos solicitados ao BNH. Apenas 2 terrenos foram desapropriados especialmente para a COHAB/SP. Pouco mais de $400 \mathrm{mil} \mathrm{m}^{2}$ de áreas dominiais foram transferidas; e 145 mil m² vieram da transferência da EMURB, de áreas desapropriadas para o metrô. A grande maioria dos terrenos comprados eram muito baratos, exatamente por serem terrenos rurais, desprovidos de infra-estrutura. (...) os terrenos representavam em média menos de 7\% do custo da edificação; e seu custo era inferior ao da terraplanagem. No entanto, esses terrenos baratos provocaram enormes custos de implantação e manutenção da infra-estrutura. (SILVA, 1997:150)
Imagem 11 - Gleba Santa Etelvina, no início dos anos de 1980, em obras de terraplenagem para implantação de conjuntos habitacionais da COHAB-SP

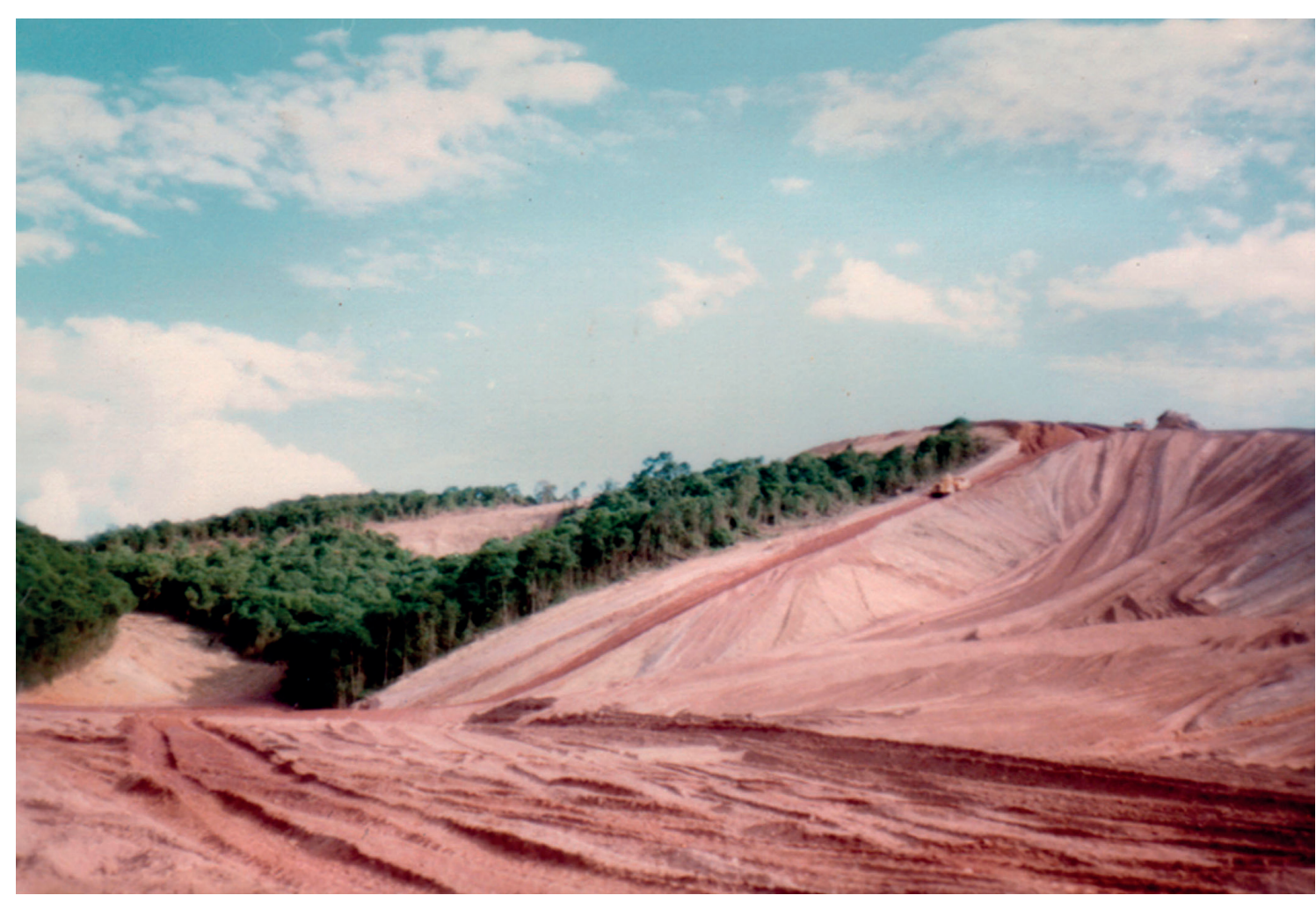

Fonte: Petrella, 2012, gentilmente cedida pelo auto:

Imagem 12 - Gleba Santa Etelvina, em 1983, obras de implantação de conjuntos habitacionais da COHAB-SP




Silva ainda classifica em três períodos distintos o processo de aquisição de terrenos da COHAB-SP. O primeiro período vai de 1965 a 1974, quando a aquisição de terras era vinculada à produção de conjuntos habitacionais em espaços de expansão rumo a periferias. Nesse período foram adquiridos 261 hectares de terras no município de São Paulo. O segundo período vai de 1976 a 1982, e foi o mais profícuo no sentido da formação do estoque de terras, quando a COHAB-SP utilizou recursos provenientes do PLANHAP e do Banco Nacional de Habitação - BNH para aquisições de grandes glebas, num total de 2135 hectares no município de São Paulo. No terceiro período, que vai de 1983 a 1991, a COHAB-SP adquiriu 497 hectares de terras associadas a programas e projetos municipais específicos. Reproduzo abaixo um resumo dos dados apresentados por Silva em sua tese:

Tabela 8 - Terras adquiridas pela COHAB-SP no município de São Paulo entre 1965 e 1991

\begin{tabular}{lcccc}
\hline & 1965 a 1975 & 1976 a 1982 & 1983 a 1991 & Total \\
\hline Terras adquiridas $\left(\mathbf{m}^{2}\right)$ & 2.661 .451 & 21.350 .762 & 4.970 .971 & 28.983 .184 \\
\hline Número de UH produzidas & 18.605 & 74.200 & 19.948 & 112.753 \\
\hline
\end{tabular}

Fonte: Silva, 1997.

Imagem 13 - Gleba Santa Etelvina, nos anos de 2000, várias gerações de conjuntos habitacionais da COHAB-SP

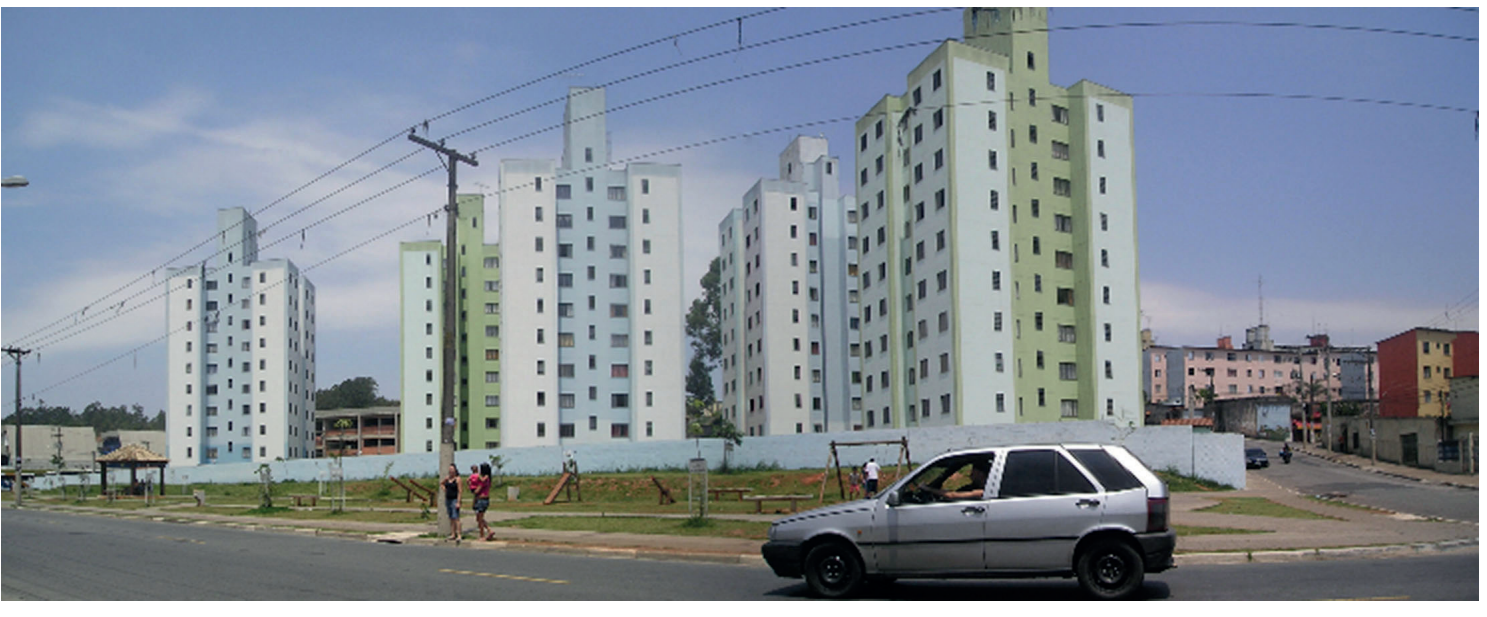

Fonte: Petrella, 2012, gentilmente cedida pelo autor.

O trabalho de Silva aponta ainda que, apesar de haver uma grande parte do estoque de terrenos da $\mathrm{COHAB}$ que ainda não foram ocupados, essas terras são inadequadas para novas ocupações, seja por problemas de litígios em relação à propriedade, seja por estarem ocupados por favelas, ou ainda por aspectos ambientais. De acordo com levantamentos elaborados pela autora em 1997, dos 1.125 hectares de glebas ainda desocupadas na Região Metropolitana de São Paulo, 350 hectares, equivalente a pouco mais de 30\% do total, estão localizados em Áreas de Proteção de Manaciais; 555 hectares, aproximadamente 50\% do total, localizam-se na Área de Proteção Ambiental do Parque do Carmo, e ainda 90 hectares, ou $8 \%$ da área total, correspondem à pedreira de Itapevi. (SILVA, 1997:151)

Tabela 9 - Empreendimentos privados de interesse social e de mercado popular lançados de 2000 a 2010 no município de São Paulo

\begin{tabular}{|l|c|l|c|}
\hline Distrito & Número de empreendimentos & Distrito & Número de empreendimentos \\
\hline Itaquera & 83 & Cursino & 9 \\
\hline Sacomã & 53 & São Miguel & 9 \\
\hline Campo Limpo & 43 & Socorro & 9 \\
\hline Jaraguá & 40 & Ipiranga & 8 \\
\hline Penha & 38 & Liberdade & 8 \\
\hline Ermelino Matarazzo & 37 & Bom Retiro & 7 \\
\hline Pirituba & 35 & Carrão & 7 \\
\hline Parque do Carmo & 32 & Cidade Ademar & 7 \\
\hline São Lucas & 27 & Mandaqui & 7 \\
\hline Capão Redondo & 26 & Moóca & 7 \\
\hline Cidade Líder & 26 & Morumbi & 6 \\
\hline Cangaiba & 25 & Vila Formosa & 5 \\
\hline Vilia Matilde & 25 & Vila Guilherme & 5 \\
\hline Vila Andrade & 23 & Vila Leopoldina & 5 \\
\hline República & 22 & Vila Medeiros & 5 \\
\hline Itaim Paulista & 20 & Artur Alvim & 4 \\
\hline Jabaquara & 20 & Barra Funda & 4 \\
\hline Vila Curuçá & 19 & Bela Vista & 4 \\
\hline Vila Jacuí & 19 & Brás & 4 \\
\hline Vila Sônia & 19 & Consolação & 4 \\
\hline São Mateus & 18 & Itaim Bibi & 4 \\
\hline Freguesia do Ó & 17 & Jaçanã & 4 \\
\hline Vila Prudente & 17 & Jardim Ângela & 4 \\
\hline José Bonifácio & 16 & Jardim Helena & 4 \\
\hline Raposo Tavares & 15 & Tremembé & 4 \\
\hline Jardim São Luis & 14 & Anhanguera & 3 \\
\hline Con & & & \\
\hline
\end{tabular}


conclusão

\begin{tabular}{|l|c|l|c|}
\hline Distrito & Número de empreendimentos & Distrito & Número de empreendimentos \\
\hline Limão & 14 & Jaguaré & 3 \\
\hline Rio Pequeno & 14 & Lapa & 3 \\
\hline Aricanduva & 13 & Santo Amaro & 3 \\
\hline Butantã & 13 & Sapopemba & 3 \\
\hline Campo Grande & 13 & Vila Mariana & 3 \\
\hline Lajeado & 13 & Belém & 2 \\
\hline Ponte Rasa & 13 & Brasilândia & 2 \\
\hline Guaianazes & 12 & Cidade Dutra & 2 \\
\hline Santa Cecilia & 12 & Pedreira & 2 \\
\hline São Domingos & 12 & Perdizes & 2 \\
\hline Tucuruvi & 12 & Pinheiros & 2 \\
\hline Casa Verde & 11 & Santana & 2 \\
\hline Vila Maria & 11 & Saúde & 2 \\
\hline Água Rasa & 10 & Jaguara & 1 \\
\hline Tatuapé & 10 & Jardim Paulista & 1 \\
\hline Cambuci & 9 & Perus & 1 \\
\hline & & TOTAL & $\mathbf{1 1 0 2}$ \\
\hline
\end{tabular}

Fonte: Embraesp/CEM 2000-2010. Elaboração da autora.

Os empreendimentos de interesse social e de mercado popular localizam-se em sua maioria nos distritos próximos aos limites do município, apresentando concentração significativa na zona leste. Entre 2000 e 2010 foram 442 empreendimentos desse padrão lançados em 22 distritos da zona leste da capital, o equivalente a 40\% do total de 1102 empreendimentos de interesse social e de mercado popular lançados no município no mesmo período. Esses empreendimentos ocupam em média $2.983 \mathrm{~m}^{2}$ de terreno por empreendimento, apresentam uma média de 83 unidades habitacionais por empreendimento, e $54 \mathrm{~m}^{2}$ área útil por unidade habitacional.

Em sua tese de doutorado, Letícia Sígolo estudou a produção residencial vertical do setor econômico na Região Metropolitana de São Paulo, identificando uma

nova cartografia da segregação socioespacial na metrópole paulistana, com o acirramento das disputas por terra urbanizada nestes novos alvos do mercado formal, regiões outrora marcadas pelas dinâmicas imobiliárias informais, deslocadas, agora, para áreas ainda descartadas pelo setor imobiliário. (Sígolo, 2014:55)
No município de São Paulo, a localização de empreendimentos residenciais do mercado privado formal tanto mais se aproxima dos limites das periferias informais quanto mais populares forem. A tabela a seguir apresenta a distribuição dos empreendimentos contratados pelo Programa Minha Casa Minha Vida entre 2009 e 2012 por distrito, de sagregadas para as faixas de atendimento 1, 2 e 3 do Programa.

Tabela 10 - Empreendimentos contratados pelo Programa Minha Casa Minha Vida entre 2009 e 2012 no município de São Paulo - Faixas 1, 2 e 3

\begin{tabular}{|l|c|c|c|c|}
\hline Distrito & Faixa 1 & Faixa 2 & Faixa 3 & Total \\
\hline Campo Limpo & & 10 & 6 & 16 \\
\hline Itaquera & 4 & 4 & 5 & 13 \\
\hline Aricanduva & & 9 & 2 & 11 \\
\hline Cidade Tiradentes & 11 & & & 11 \\
\hline Jaraguá & & 5 & 5 & 10 \\
\hline Cidade Líder & 3 & 3 & 3 & 9 \\
\hline Vila Prudente & & 3 & 6 & 9 \\
\hline Capão Redondo & 6 & & 2 & 8 \\
\hline Sacomã & & & 8 & 8 \\
\hline Cursino & & 1 & 6 & 7 \\
\hline José Bonifácio & 7 & & & 7 \\
\hline Vila Curuçá & & 3 & 4 & 7 \\
\hline Freguesia do Ó & 2 & 1 & 3 & 6 \\
\hline São Mateus & & 5 & 1 & 6 \\
\hline Sapopemba & 5 & & & 5 \\
\hline Vila Jacuí & & 3 & 2 & 5 \\
\hline Cidade Dutra & & 2 & 2 & 4 \\
\hline Jardim São Luis & 1 & 2 & 1 & 4 \\
\hline Lajeado & 2 & 1 & 1 & 4 \\
\hline Artur Alvim & 3 & & & 3 \\
\hline Barra Funda & & 3 & & 3 \\
\hline Cachoeirinha & & 1 & 2 & 3 \\
\hline Cambuci & & 3 & & 3 \\
\hline Ermelino Matarazzo & & 2 & 1 & 3 \\
\hline Guaianazes & & & 1 & 3 \\
\hline Limão & & 2 & 1 & 3 \\
\hline Penha & & & & 2 \\
\hline Brás & & & & 2 \\
\hline Cangaíba \\
Continua & & & & \\
\hline
\end{tabular}


conclusão

\begin{tabular}{|l|c|c|c|c|}
\hline Distrito & Faixa 1 & Faixa 2 & Faixa 3 & Total \\
\hline Casa Verde & & 2 & & 2 \\
\hline Itaim Paulista & & 2 & & 2 \\
\hline Jardim Ângela & & 1 & 1 & 2 \\
\hline Moóca & & 2 & & 2 \\
\hline Raposo Tavares & 2 & & & 2 \\
\hline República & & 1 & 1 & 2 \\
\hline São Lucas & & & 2 & 2 \\
\hline Vila Maria & & 1 & 1 & 2 \\
\hline Água Rasa & & 1 & & 1 \\
\hline Brasilândia & & & 1 & 1 \\
\hline Carrão & & & & 1 \\
\hline Ipiranga & & & 1 & 1 \\
\hline Jabaquara & & 1 & & 1 \\
\hline Jaçanã & & & 1 & 1 \\
\hline Pirituba & & & & 1 \\
\hline Rio Pequeno & & & & 1 \\
\hline Santo Amaro & & & 1 & 1 \\
\hline São Miguel Paulista & & $\mathbf{8 1}$ & $\mathbf{7 8}$ & $\mathbf{2 0 8}$ \\
\hline São Rafael & 1 & & & 1 \\
\hline Tremembé & & & & 1 \\
\hline Vila Formosa & & & & 1 \\
\hline Vila Matilde & & & & 1 \\
\hline TOTAL & & & & 1 \\
\hline
\end{tabular}

Fonte: LabCidade 2014. Elaboraçăo da autora.

Os empreendimentos contratados pelo Programa Minha Casa Minha Vida entre 2009 e 2012 somam um total de 208 no município de São Paulo. Dentre esses, a maioria são empreendimentos da Faixa 2 de atendimento do Programa. Foram 81 empreendimentos, ou 39\% do total, destinados a famílias com renda mensal de $\mathrm{R} \$ 1.600,01$ a $\mathrm{R} \$ 3.275,00$. A Faixa 3, que compreende famílias de maior rendimento inseridas no Programa, de $\mathrm{R} \$ 3.275,01$ a $\mathrm{R} \$ 5.000,00$, contou com 78 empreendimentos contratados no município de São Paulo no mesmo período, o equivalente a 37,5\% do total de empreendimentos. A Faixa 1, que beneficia famílias de menor rendimento, desde os sem rendimentos até a $\mathrm{R} \$ 1.600,00$ mensais, somou 49 empreendimentos contratados, representando apenas $23,5 \%$ do total no município entre 2009 e 2012.
Dentre os quatro distritos que mais receberam empreendimentos do Minha Casa Minha Vida, três estão localizados na zona leste do município. Campo Limpo, na zona sul do município, foi o distrito que mais recebeu empreendimentos do MCMV: dezesseis empreendimentos, sendo dez para a Faixa 2 e seis para a Faixa 3 do Programa. Itaquera, na zona leste, foi o segundo distrito em número de empreendimentos MCMV, treze no total, distribuídos de forma balanceada entre as faixas de rendimentos dos beneficiários: Foram quatro empreendimentos destinados à Faixa 1, quatro para a Faixa 2, e cinco para a Faixa 3. Também na zona leste, Aricanduva somou onze empreendimentos contratados pelo MCMV, nove deles para a Faixa 2, e dois para a Faixa 3 do Programa. O distrito de Cidade Tiradentes, localizado no extremo leste do município, concentrou onze empreendimentos do Programa Minha Casa Minha Vida, todos destinados à Faixa 1.

Os 49 empreendimentos contratados na Faixa 1 do MCMV no município de São Paulo estão distribuídos por 13 distritos. 33 empreendimentos, ou o equivalente a $67 \%$ do total nessa faixa de atendimento, estão localizados na zona leste. Capão Redondo e Jardim São Luís, no extremo da zona sul da capital, concentram sete empreendimentos contratados na Faixa 1 do programa, ou 14\% do total nessa faixa. Em Sapopemba, no extremo sudeste do município, estão localizados 5 empreendimentos Faixa 1, 10\% do total nessa faixa de rendimentos. Raposo Tavares, no extremo Oeste, e Freguesia do Ó, na zona Norte do município, abrigam cada um dois empreendimentos da Faixa 1, ou 4,5\% do total em cada um desses distritos.

Os empreendimentos da Faixa 2 do programa Minha Casa Minha Vida estão distribuídos por 33 distritos. O distrito que mais concentra empreendimentos contratados entre 2009 e 2012 é Campo Limpo, no extremo sul do município, com 10 empreendimentos, ou $12 \%$ do total nessa faixa. Em seguida vem Aricanduva, na zona Leste, com 9 empreendimentos, ou $11 \%$ do total. 
Os 78 empreendimentos contratados na Faixa 3 do Programa Minha Casa Minha Vida distribuem-se por 34 distritos do município de São Paulo. O distrito que mais concentra empreendimentos da Faixa 3 é Sapopemba, na zona sudeste, com 8 empreendimentos, ou $10 \%$ do total nessa faixa de atendimento. Em seguida, com 6 empreendimentos, ou 7,5\% cada um, temos Cursino, na zona Sudeste, e Campo Limpo, na zona Sul do município.

O único distrito da área central do município que abriga empreendimentos do Minha Casa Minha Vida é República, com um empreendimento da Faixa 2 e um da Faixa 3. Bastante próximos ao Centro da capital, Barra Funda, na zona Oeste, apresenta 3 empreendimentos na Faixa 2, e Brás, na zona Leste, 2 empreendimentos, também na Faixa 2.
Imagens 14 a 17 - Empreendimento Faixa 1 - Cachoeira do Arrependido, na Cohab Raposo Tavares
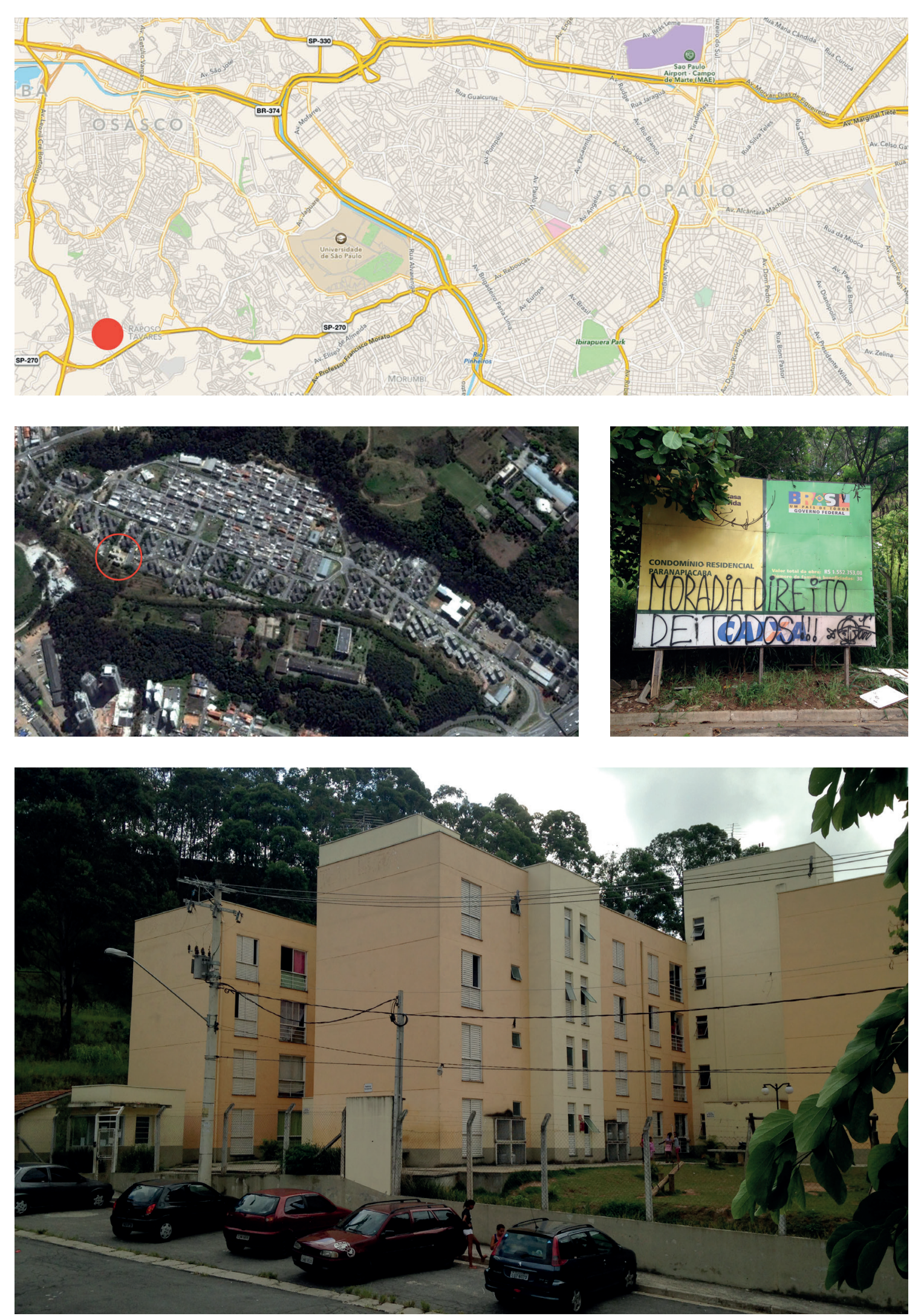

Fontes: Google Maps, 2015; Google Earth, 2015; Acervo da autora, 2015. 
Imagens 18 a 20 - Empreendimento MCMV Faixa 2 - Rua Leais Paulistanos, Ipiranga
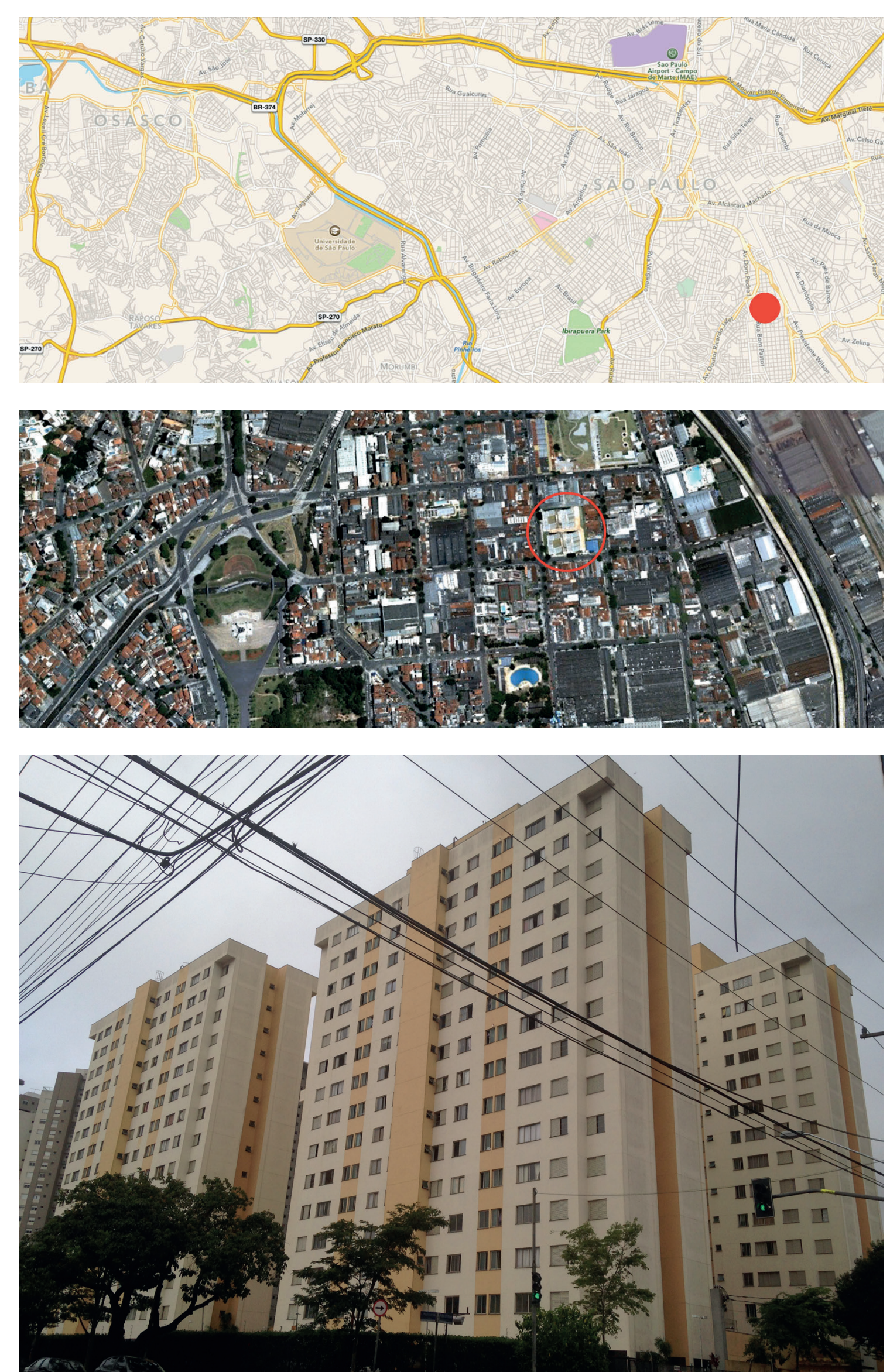

Fontes: Google Maps, 2015; Google Earth, 2015; Acervo da autora, 2015.
Imagens 21 a 23 - Empreendimento Faixa 3 - Rua Milton Soares, Rio Pequeno
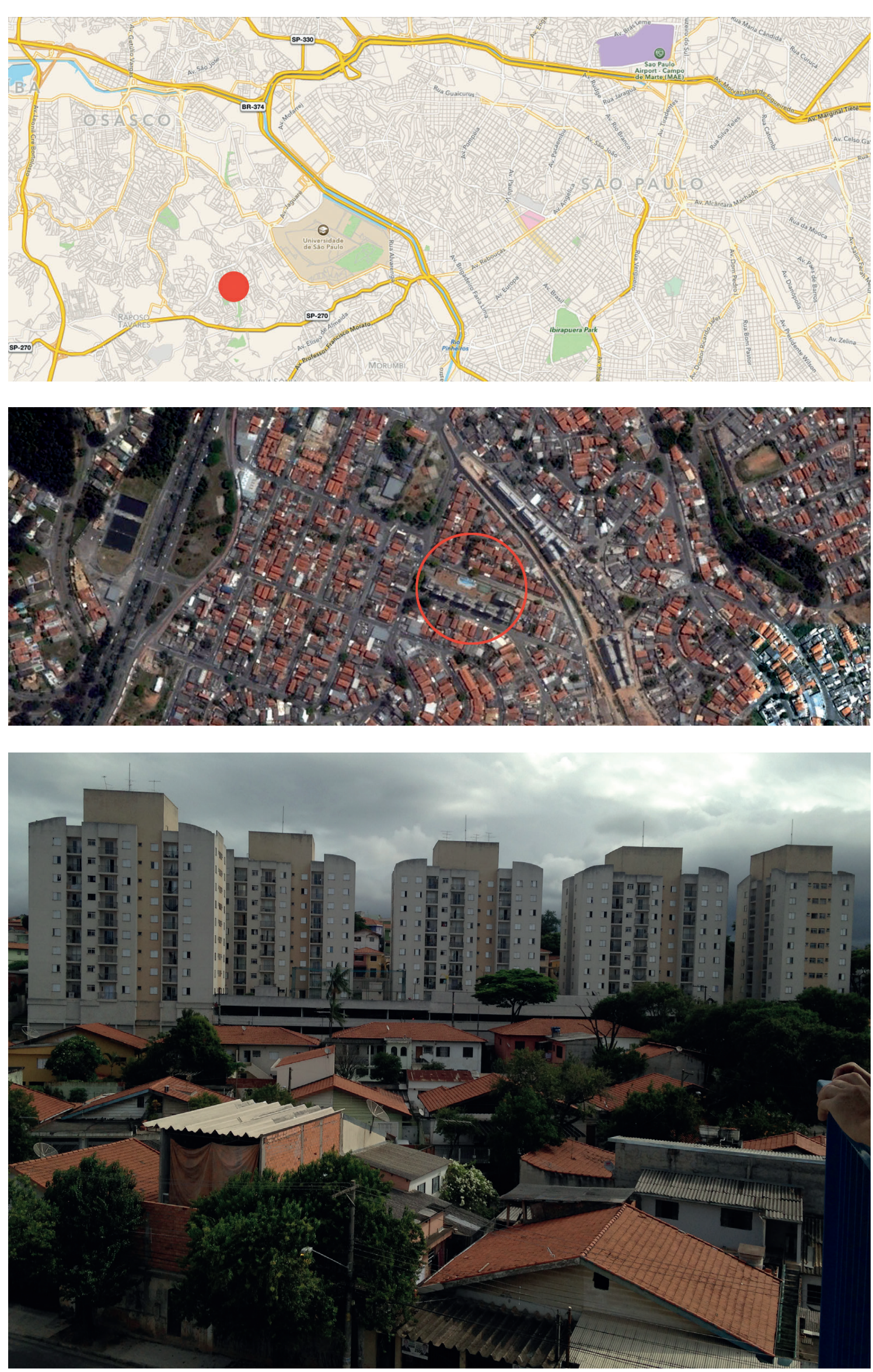

Fontes: Google Maps, 2015; Google Earth, 2015; Acervo da autora, 2015. 
Imagens 24 a 26 - Empreendimento MCMV Faixa 2 - Rua Major Sertório, República


Fontes: Google Maps, 2015; Google Earth, 2015; Acervo da autora, 2015.
Neste Capítulo 3, buscamos identificar o padrão de localização do incremento na produção habitacional de interesse social e de mercado trazido pelo boom imobiliário dos anos de 2000, que se mostrou bastante concentrado nas periferias do município de São Paulo. Fica uma questão que procuraremos responder no Capítulo 4: Qual é o alcance do planejamento territorial municipal no sentido de reverter a tendência à reprodução dos padrões de segregação espacial que resistem em nossas cidades? 
CAPÍTULO 4

Potencial da Cota de Solidariedade como instrumento de ampliação do acesso à terra para provisão de habitação de interesse social 
Nos capítulos anteriores procuramos apresentar condições estruturais que guiaram o salto da produção imobiliária ocorrido na década de 2000. A ampliação de crédito sem uma transformação da estrutura fundiária existente resultou na reprodução de padrões segregadores de produção habitacional e urbana. Ainda que nesse período tenha havido um grande incremento no número de unidades residenciais de interesse social e de mercado popular, as localizações dessas unidades em áreas periféricas com pouco acesso a infraestrutura e serviços urbanos gera um aprofundamento da desigualdade socioespacial.

Neste capítulo apresentamos uma investigação de tentativas, por parte do poder público municipal, de superação de entraves ao acesso à terra destinada ao uso habitacional de interesse social. Por um lado, detectamos um movimento que avança com a proposição de instrumentos jurídicos e urbanísticos que rompam com o padrão concentrador de propriedade de terras que reproduz a segregação sócio-espacial, e, por outro lado, a atuação de proprietários de terras e representantes do mercado imobiliário no processo de definição desses instrumentos no sentido de minimizar seus efeitos transformadores.

Durante a revisão do Plano Diretor do município de São Paulo, entre 2013 e 2014, houve esforços no sentido de definir alguns instrumentos urbanísticos com potencial de rompimento com a retenção especulativa de terras bem localizadas. Um desses instrumentos, a Cota de Solidariedade, sofreu alterações durante o processo de aprovação que praticamente anularam o seu potencial transformador. Outros instrumentos, podem passar por resistência por meio de processos judiciais que impeçam sua aplicação. Ainda, há a chance de que alguns instrumentos deliberadamente não sejam aplicados.

Como num jogo em que se deixa o adversário avançar pela certeza de na próxima jogada fazê-lo recuar, os proprietários de terras e de capital financeiro não criam muitos conflitos com a o poder legislativo nem com a administração executiva do município. Participam em momentos cruciais de definição de leis, vetando pontos fundamentais ou inserindo artigos que desviem a aplicação da legislação de seu objetivo principal, e principalmente, garantem que algumas leis não sejam aplicadas, atuando via sistema judiciário, por meio de liminares e declarações de inconstitucionalidade de instrumentos potencialmente inovadores.

\section{1 - O Plano Diretor Estratégico de São Paulo de 2014}

Entre os anos de 2013 e 2014 foi desenvolvido pelo poder executivo municipal e aprovado pela Câmara Municipal do município de São Paulo o Plano Diretor Estratégico - PDE, Lei 16.650/2014. Nas palavras do secretário municipal de Desenvolvimento Urbano, Fernando de Mello Franco, durante a cerimônia de sanção do Plano Diretor, em julho de 2014,

O Plano tem como um dos eixos centrais a questão habitacional e a produção de moradias populares. Além de avançar na reserva de terras, que é um bem finito, articula-se ainda novas formas de financiamento e captação de recursos para a produção de moradias. ${ }^{1}$

O gargalo da aquisição de terras aplica-se às políticas públicas municipais em geral e também à de Habitação de Interesse Social - HIS. Ainda que haja recursos disponíveis no orçamento ou em programas do governo federal para a construção de empreendimentos de HIS, a situação de fato é que ou os terrenos municipais desocupados estão em localizações onde já há uma alta densidade residencial - devendo-se adensar nesse local as oportunidades de emprego, serviços, transporte, lazer etc, ou nas localizações onde seria ideal adensar a oferta de habitação de interesse social não há disponibilidade de terrenos, que impõe a necessidade de longos e custosos processos de desapropriação.

Para a iniciativa privada, a aquisição de terras é também limitadora da capacidade de produção de habitação de interesse social, que vem sendo fomentada em grande medida pela ampliação da oferta de financiamento e crédito para camadas de mais baixa renda da população, por meio do Programa Minha Casa Minha Vida. Preço e complexidade de licenciamento são apontados pelos empreendedores imobiliários como os maiores entraves a essa produção. 
O PDE 2014 propõe inovações ao prever instrumentos urbanísticos cuja aplicação permite articular aquisição de terrenos pelo município destinada à produção de habitação de interesse social, buscando ampliar o número de unidades de HIS produzidas tanto por iniciativa pública como privada. A Função Social da Propriedade e o IPTU Progressivo, a ampliação das áreas demarcadas como ZEIS e a Cota de Solidariedade são exemplos desse caminho.

Presente desde o Plano Diretor Estratégico de 2002, o instrumento de Parcelamento, Edificação e Utilização Compulsórios - PEUC foi novamente incluído no PDE de 2014, e mais importante que a presença na lei foi a formação, em 2014, de um departamento na estrutura da Secretaria de Desenvolvimento Urbano - SMDU com a função de implementar esse instrumento, com a identificação e notificação de imóveis subutilizados, que é o marco inicial da aplicação da PEUC, e em seguida com o monitoramento do cumprimento da obrigação definida pela notificação (se são de fato parcelados, edificados ou utilizados, e também se estão pagando o IPTU progressivo), até uma eventual indicação de desapropriação do imóvel. O desafio maior da aplicação desse instrumento, de acordo com o Diretor do Departamento de Cumprimento da Função Social da Propriedade DCFSP, Fernando Guilherme Bruno, é a continuidade e a consolidação da PEUC "como um instrumento de Estado, não de governo" ${ }^{2}$, nas palavras de Bruno, que destaca ainda a importância do cumprimento da função social da propriedade para o questionamento, por diversos segmentos da sociedade, da noção de propriedade como direito absoluto.

A ampliação em 107\% da superfície de terras demarcadas como ZEIS no novo Plano Diretor pode ser considerada um reforço na luta pela implementação dessa importante reserva de terras para a habitação de interesse social, que no entanto apresenta barreiras de difícil superação. Em sua tese de doutorado, Caio Santo Amore coloca uma questão que pode ser ampliada para além das ZEIS, no sentido da implementação de outros instrumentos urbanísticos e jurídicos, assim como da política de habitação de interesse social como um todo, e por esse motivo também pode ser norteadora desta pesquisa:
A produção de habitações para os pobres em áreas bem localizadas é, de fato, o nó! E a disputa pela terra é estrutural na análise do impasse da Reforma Urbana. Mas como explicar que a cidade, depois de tantos anos da luta, mantenha um padrão de urbanização que segrega os mais pobres e praticamente impede que o potencial das ZEIS se realize plenamente? (Santo Amore, 2013:248)

Santo Amore reconhece que não é pelo viés das lutas por Reforma Urbana que se vem encaminhando a aplicação das ZEIS, mas sim por uma ideal e pontual concretização de um Estado de bem-estar social de fato inexistente no Brasil. Como se fosse possível, num contexto de capitalismo periférico, garantir a democratização do acesso à terra por meio da aplicação de instrumentos urbanísticos, sem que se altere a estrutura fundiária, de riqueza em geral e de renda.

\section{2 - 0 instrumento urbanístico Cota de Solidariedade}

A Cota de Solidariedade é um instrumento urbanístico com potencial de transformação do padrão de produção de habitação de interesse social ao propor o equacionamento de dois temas fundamentais da política urbana: a aquisição de terras e a política de habitação de interesse social. A aplicação desse instrumento é obrigatória para a obtenção do certificado de conclusão de obra de empreendimentos com área computável maior que $20.000 \mathrm{~m}^{2}$, vinculando o licenciamento de grandes empreendimentos à destinação de unidades de habitação de interesse social, doação de terrenos ou de recursos financeiros ao município, em quatro alternativas à escolha do empreendedor.

As duas questões que propomos responder neste capítulo são:

i) Qual é o potencial de produção de habitação de interesse social e de aquisição de terrenos para esse fim por meio da aplicação da Cota de Solidariedade?; e

ii) Qual é o potencial de transformação da desigualdade sócio-espacial desse instrumento urbanístico? 


\subsection{1 - Potencial de produção de habitação de interesse social por meio da}

\section{Cota de Solidariedade}

A Cota de Solidariedade é aplicável a empreendimentos com área construída computável maior que $20.000 \mathrm{~m}^{2}$. De acordo com o Artigo 111 da Lei 16.050 de 2014,

Fica estabelecida como exigência para o certificado de conclusão de empreendimentos imobiliários de grande porte ou implantação de planos e projetos urbanísticos a Cota de Solidariedade, que consiste na produção de Habitação de Interesse Social pelo próprio promotor, doação de terrenos para produção de HIS ou a doação de recursos ao Município para fins de produção de Habitação de Interesse Social e equipamentos públicos sociais complementares à moradia.

Parágrafo único. A doação prevista no "caput" não exime a necessidade de destinação de áreas ao Município nos termos da legislação de parcelamento do solo.

Art. 112. Os empreendimentos com área construída computável superior a $20.000 \mathrm{~m}^{2}$ (vinte mil metros quadrados) ficam obrigados a destinar 10\% (dez por cento) da área construida computável para Habitação de Interesse Social, voltada a atender famílias com renda até 6 (seis) salários mínimos, de acordo com regulamentação definida nesta lei.

$\$ 1^{\circ} \mathrm{A}$ área construída destinada à Habitação de Interesse Social no empreendimento referido no "caput" desse artigo será considerada não computável.

$\$ 2^{\circ}$ Alternativamente ao cumprimento da exigência estabelecida no "caput" deste artigo, o empreendedor poderá:

I - produzir Empreendimento de Habitação de Interesse Social com no mínimo a mesma área construida exigida no "caput" desse artigo em outro terreno, desde que situado na Macrozona de Estruturação e Qualificação Urbana, excluída a Macroárea de Redução da Vulnerabilidade Urbana e os Setores Jacu-Pêssego, Arco Leste, Noroeste e Fernão Dias da Macroárea de Estruturação Metropolitana;

II - doar terreno de valor equivalente a 10\% (dez por cento) do valor da área total do terreno do empreendimento, calculado conforme Cadastro de Valor de Terreno para fins de Outorga Onerosa, situado na Macrozona de Estruturação e Qualificação Urbana, excluída a Macroárea de Redução da Vulnerabilidade Urbana e os Setores Jacu-Pêssego, Arco Leste, Noroeste e Fernão Dias da Macroárea de Estruturação Metropolitana;

III - depositar no Fundo de Desenvolvimento Urbano - FUNDURB, em sua conta segregada para Habitação de Interesse Social, 10\% (dez por cento) do valor da área total do terreno calculado conforme Cadastro de Valor de Terreno para fins de Outorga Onerosa, destinado à aquisição de terreno ou subsídio para produção de HIS, preferencialmente em ZEIS 3.

$\$ 3^{\circ}$ Atendida a exigência estabelecida no "caput", inclusive pelas alternativas previstas no $\$ 2^{\circ}$, o empreendimento poderá beneficiar-se de acréscimo de $10 \%$ (dez por cento) na área computável, obtida mediante o pagamento da outorga onerosa.

$\$ 4^{\circ} \mathrm{O}$ Executivo deverá fiscalizar a destinação das unidades, garantindo o atendimento da faixa de renda prevista no "caput" deste artigo.

$\$ 5^{\circ} \mathrm{A}$ obrigação estabelecida no "caput" se estende aos empreendimentos com área construída computável inferior a $20.000 \mathrm{~m}^{2}$ (vinte mil metros quadrados), quando:

a) originários de desmembramentos aprovados após a publicação desta lei, com área computável equivalente superior a $20.000 \mathrm{~m}^{2}$ (vinte mil metros quadrados), calculada conforme a equação a seguir:

$A C c e=(A C c \times A T o) / A T d$, onde:

ACce - área construída computável equivalente;

$A C c$ - área construída computável do terreno desmembrado;

ATo - área do terreno original;

ATd - área do terreno desmembrado;

$\$ 6^{\circ} \mathrm{A}$ doação de área prevista do inciso II do $\$ 2^{\circ}$ deste artigo só será aceita após a análise e aprovação do órgão competente.

$\$ 7^{\circ}$ Os empreendimentos de uso não residencial localizados em áreas onde o fator de planejamento para os usos nR é igual a zero, de acordo com o Quadro 6 desta lei, ficam dispensados da obrigação determinada no "caput".

A Cota de Solidariedade conecta diretamente o resultado da produção imobiliária de grande porte à viabilização da produção de habitação de interesse social, estabelecendo como condição para a obtenção do certificado de conclusão da obra a destinação de unidades de Habitação de Interesse Social - HIS, a doação de terrenos ao município ou de valor monetário ao Fundo de Desenvolvimento Urbano - FUNDURB, por meio de uma das seguintes quatro opções, à escolha do empreendedor. 
i) Destinação de área equivalente a 10\% da área construída computável do empreendimento em unidades de Habitação de Interesse Social - HIS 1 ou HIS $2^{3}$. Esse percentual é adicional ao empreendimento original, ou seja, a área equivalente aos 10\% de HIS não é considerada área computável para o cálculo do coeficiente de aproveitamento definido pela zona de uso.

Teríamos, nesse caso, um possível incremento 10\% na densidade construída de grandes empreendimentos, e um lucro adicional ao empreendedor pela venda dos $10 \%$ da área computável. Não fica claro no PDE o que significa "destinação", nem a forma de gestão das unidades a serem destinadas a HIS, o que deverá ser definido por meio de decreto municipal regulamentando a aplicação da Cota de Solidariedade.

ii) Construção de empreendimento de Habitação de Interesse Social - HIS com área computável equivalente a no mínimo $10 \%$ da área computável do empreendimento gerador da Cota de Solidariedade em terreno localizado na "Macrozona de Estruturação e Qualificação Urbana, excluída a Macroárea de Redução da Vulnerabilidade Urbana e os Setores Jacu-Pêssego, Arco Leste, Noroeste e Fernão Dias da Macroárea de Estruturação Metropolitana”.

Também essa opção não deixa clara a forma de utilização dos imóveis de HIS após a sua produção.

A localização permitida para esses empreendimentos abrange uma grande parte da cidade com acesso a infraestrutura e serviços urbanos bastante diversificados. Os terrenos vagos que poderiam ser utilizados para essa opção de aplicação da Cota são os maiores de $500 \mathrm{~m}^{2}$ localizados nos Eixos de Estruturação da Transformação Urbana, que aplicando o coeficiente de aproveitamento máximo igual a 4 resultam em empreendimentos maiores que $2.000 \mathrm{~m}^{2}$ (10 por cento de $20.000 \mathrm{~m}^{2}$ ), e também os maiores de $1000 \mathrm{~m}^{2}$ localizados fora dos Eixos, cujo coeficiente máximo é 2. São 178 lotes vagos com essas condições, somando quase 65 milhões de metros quadrados de superfície, com grande variação na superfície dos lotes e nos valores por $\mathrm{m}^{2}$, conforme Quadro 14 do PDE - Valor do $\mathrm{m}^{2}$ para cálculo de Outorga Onerosa. Além dos terrenos vagos, terrenos construídos também deverão ser utilizados para essa produção, no entanto, por ser muito difícil prever essa dinâmica, estamos considerando para a simulação apenas os terrenos vagos.

iii) Doação de terreno com valor equivalente a $10 \%$ da valor do terreno do empreendimento a ser licenciado, localizado na "Macrozona de Estruturação e Qualificação Urbana, excluída a Macroárea de Redução da Vulnerabilidade Urbana e os Setores Jacu-Pêssego, Arco Leste, Noroeste e Fernão Dias da Macroárea de Estruturação Metropolitana"

iv) Doação de valor equivalente a $10 \%$ do valor do terreno a ser licenciado, em depósito no Fundo Municipal de Desenvolvimento Urbano - FUNDURB. Esse recurso será direcionado à conta segregada para HIS do FUNDURB, suplementarmente aos 30\% destinados a HIS por definição do PDE 2014 (ver Gráfico 9). 
Gráfico 9 - Modelo simplificado de origem e destinação de recursos do Fundo de Desenvolvimento Urbano - FUNDURB

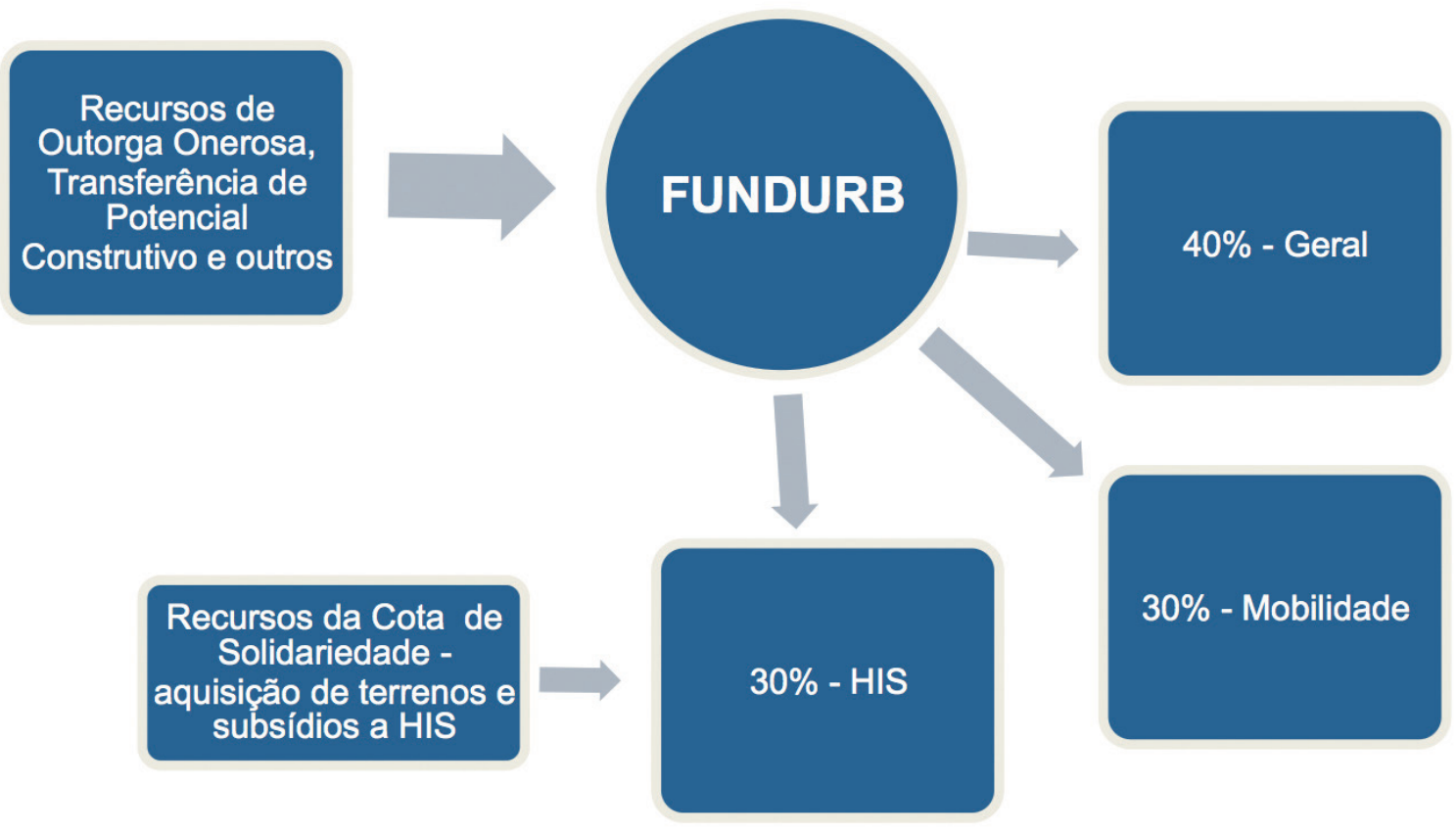

Fonte: Lei 16.650/2014, PDE do município de São Paulo.

Para a avaliação do potencial de produção de habitação de interesse social por meio da aplicação da Cota de Solidariedade, utilizamos dados de área útil como proxy de área computável, devido à inexistência de dados sistematizados sobre área computável.

Uma análise inicial de dados sobre lançamentos imobiliários produzidos pela Embraesp mostrou que entre 2000 e 2010, dentre o total de lançamentos imobiliários residenciais e não residenciais no município de São Paulo, foram produzidos 159 empreendimentos com área útil maior que $20.000 \mathrm{~m}^{2}$, sendo 138 residenciais, 8 comerciais e 13 shopping centers. Esse número representa apenas 2,5\% do número total de lançamentos imobiliários no período. A área útil total produzida e a área de terrenos consumida pelos empreendimentos com área útil maior que $20.000 \mathrm{~m}^{2}$ lançados entre 2000 e 2010 representam $14 \%$ do total nesse período.
Os empreendimentos aos quais se aplicaria a Cota de Solidariedade consumiram um total de $2.107 .907 \mathrm{~m}^{2}$ de terreno, produzindo $4.483 .983 \mathrm{~m}^{2}$ de área útil, e 28.944 unidades habitacionais. Apresentam, em média, $13.257 \mathrm{~m}^{2}$ de área total de terreno, $28.201 \mathrm{~m}^{2}$ de área útil total e 210 unidades habitacionais por empreendimento, o que equivale a um coeficiente de aproveitamento médio 2,13. A Tabela 4 traz de forma consolidada o número de lançamentos, área total de terreno $\mathrm{em}^{2}$, área útil total $\mathrm{em}^{2}$, e o número de unidades habitacionais correspondentes aos dados da Embraesp/CEM e ABRASCE entre os anos de 2000 e 2010

Tabela 11 - Produção imobiliária com área útil maior que 20.000 m2 entre 2000 e 2010

\begin{tabular}{lcccc}
\hline & Lançamentos & $\begin{array}{c}\text { Área total de } \\
\text { terreno }\left(\mathbf{m}^{2}\right)\end{array}$ & $\begin{array}{c}\text { Área útil total } \\
\left(\mathbf{m}^{2}\right)\end{array}$ & $\begin{array}{c}\text { Unidades } \\
\text { habitacionais }\end{array}$ \\
\hline $\begin{array}{l}\text { Total de empreendimentos lançados } \\
\text { entre 2000 e 2010 }\end{array}$ & 6.828 & 15.147 .851 & 32.578 .320 & 355.106 \\
\hline $\begin{array}{l}\text { Empreendimentos lançados entre } \\
\begin{array}{l}2000 \text { e 2010 com mais de 20.000 } \mathrm{m}^{2} \\
\text { de área útil }\end{array}\end{array}$ & 159 & 2.107 .907 & 4.483 .983 & 28.944 \\
\hline \% em relação ao total & $2,5 \%$ & $14 \%$ & $14 \%$ & $8 \%$ \\
\hline
\end{tabular}

Fonte: Elaboraçăo da autora a partir de dados Embraesp/CEM 2000-2010 e ABRASCE 2000-2010.

As tipologias aplicadas à produção imobiliária de grandes empreendimentos faz com que $2,5 \%$ do total de empreendimentos lançados no período represente $14 \%$ do tota de área de terreno e de área útil, e $8 \%$ do total de unidades habitacionais adicionadas. O Mapa 6, a seguir, permite visualizar a localização dos lançamentos sobre os quais se aplicaria a cota de solidariedade (com área computável construída acima de $20.000 \mathrm{~m}^{2}$ ). É possível ver que esses grandes empreendimentos localizam-se preferencialmente nos limites das áreas já estruturadas da cidade, muitos no Quadrante Sudoeste e na Zona Leste, em sua porção mais próxima ao Centro. 
Mapa 6 - Empreendimentos com área útil maior que $20.000 \mathrm{~m} 2$ lançados entre 2000 e 2010

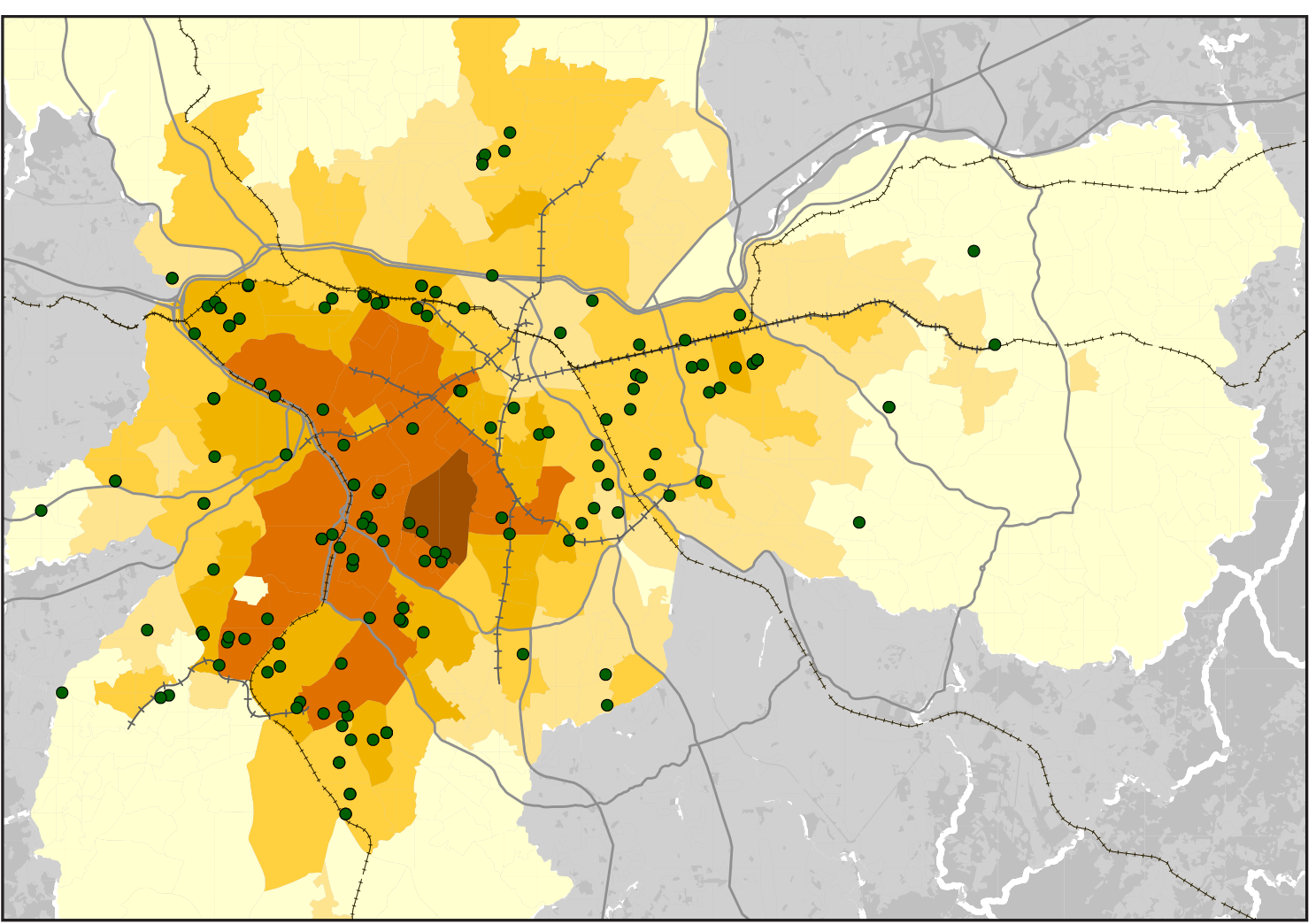

Empreendimentos Residenciais e Não Residenciais (2000-2010) Renda Média Mensal $(\mathrm{R} \$)$ CEM, Centro de Estudos da Metrópole, 201 2010 Censo Demográfico

Area Util igual ou superior a $20.000 \mathrm{~m}^{2}$ Abaixo de $\mathrm{R} \$ 680,00$

680 a 1.000

1.000 a 2.000

2.000 a 3.000

3.000 a 5.000

Acima de $\mathrm{R} \$ 5.000,00$

Fonte: Embraesp/CEM 2000-2010, PDE 2014. Elaboraçāo da autora. Cartografa: Edson Capitânio, 2014

A Tabela 12 a seguir traz uma noção pormenorizada desses lançamentos entre 2000 e 2010 , contendo o número de empreendimentos com área útil superior a $20.000 \mathrm{~m}^{2}$ distribuídos por distritos de São Paulo. Note-se que os nove primeiros distritos - aqueles que receberam maior número de lançamentos no período dentro da faixa aqui trabalhada - perfazem praticamente metade do total verificado para a cidade como um todo.
Tabela 12 - Empreendimentos com área útil > $20.000 \mathrm{~m}^{2}$ lançados entre 2000 e 2010

\begin{tabular}{|c|c|c|c|}
\hline Distrito &  & Distrito & 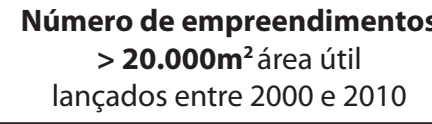 \\
\hline Campo Grande & 12 & Consolação & 2 \\
\hline Barra Funda & 11 & Jaguara & 2 \\
\hline Vila Leopoldina & 10 & Lapa & 2 \\
\hline Santo Amaro & 10 & Liberdade & 2 \\
\hline Itaim Bibi & 9 & Sacomã & 2 \\
\hline Ipiranga & 7 & Santana & 2 \\
\hline Mooca & 7 & Vila Formosa & 2 \\
\hline Vila Andrade & 7 & Vila Mariana & 2 \\
\hline Moema & 6 & Bela Vista & 1 \\
\hline Tatuapé & 6 & Belém & 1 \\
\hline Campo Belo & 5 & Bras & 1 \\
\hline Carrão & 5 & Cambuci & 1 \\
\hline Mandaqui & 4 & Cursino & 1 \\
\hline Morumbi & 4 & Jabaquara & 1 \\
\hline Jaguaré & 3 & Jardim Paulista & 1 \\
\hline Pinheiros & 3 & Jardim São Luis & 1 \\
\hline Rio Pequeno & 3 & Pari & 1 \\
\hline Vila Prudente & 3 & Perdizes & 1 \\
\hline Vila Sônia & 3 & Ponte Rasa & 1 \\
\hline Alto de Pinheiros & 3 & Raposo Tavares & 1 \\
\hline Campo Limpo & 3 & Santa Cecília & 1 \\
\hline Butantã & 2 & Sapopemba & 1 \\
\hline \multirow[t]{2}{*}{ Cidade Líder } & 2 & Itaquera & 1 \\
\hline & & Total & 159 \\
\hline
\end{tabular}

Fonte: Elaboração da autora a partir de dados Embraesp/CEM 2000-2010.

Dentre o total de 159 empreendimentos que teriam gerado Cota de Solidariedade se esse instrumento fosse aplicável no período entre 2000 e 2010, 48 \% estão localizados no setor sudoeste ${ }^{4}$ da cidade, coincidindo com a concentração de domicílios de alta renda e de oferta de empregos, como vemos nos mapas 7 e 8, abaixo. O Mapa 7 mostra a porcentagem de famílias com rendimentos acima de 20 salários mínimos por distrito e o Mapa 8, o número de empregos formais por distrito do município.

4. O setor sudoeste da cidade de São Paulo, conforme estudo de Flavio Villaça em seu livro Espaço Intra-urbano no Brasil, Jardim Paulista Lapa Liberdade, Moema Morumbi Perdies, Pinheiros, Santa Cecilia Santo Amaro, Sá́de, Vila Andrade, Vila 
Mapa 7 - Domicílios com renda domiciliar maior que 20 salários mínimos


Fonte: Ministério do Trabalho e Emprego. RAS 2012 oração SMDU- DEINFO
Mapa 8 - Distribuição do

emprego formal
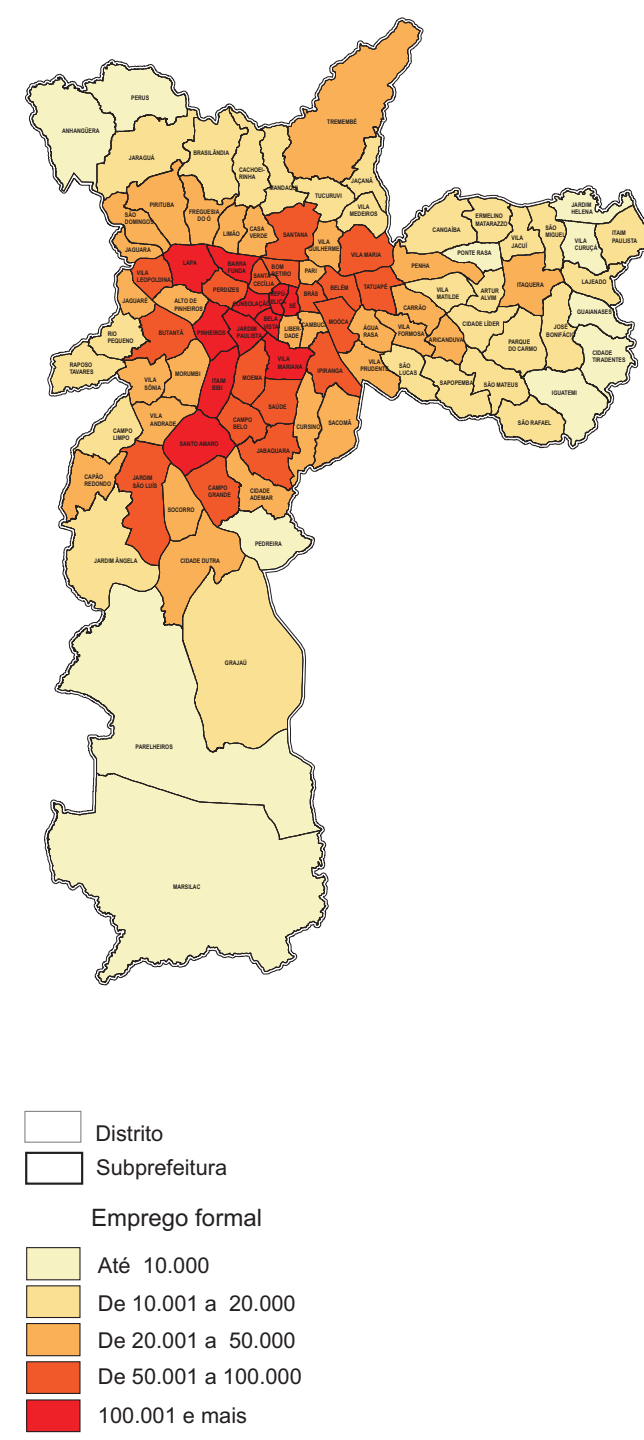

Fonte: IBGE. Censo 2010

A fim de elaborar uma avaliação do potencial de produção de habitação de interesse social da Cota de Solidariedade, tomamos como base a produção imobiliária no município de São Paulo entre os anos de 2000 e 2010. O potencial tanto numérico como de localização varia muito dentre as quatro opções de aplicação do instrumento, como veremos a seguir.

Opção 1: Destinação de 10\% da área computável adicional em HIS no mesmo local

A aplicação da Cota de Solidariedade por meio de destinação de área equivalente a $10 \%$ do empreendimento em unidades habitacionais de interesse social teria produzido $448.398 \mathrm{~m}^{2}$ de área útil de HIS entre 2000 e 2010. Se localizadas no mesmo empreendimento, as unidades de HIS adicionais não contam como área computável, ou seja, os empreendimentos poderão ter coeficiente de aproveitamento $10 \%$ maior que o permitido para o terreno, sem o pagamento de outorga onerosa.

Considerando a área útil mínima da unidade de HIS de $24 \mathrm{~m}^{2}$ (Art. 44, I, Decreto 44.667/2004), teria sido possível produzir até 18.683 unidades de HIS por meio da aplicação da Cota de Solidariedade entre 2000 e 2010, o que representa 4\% do déficit habitacional urbano no município de São Paulo do ano de 2010, que era de 471.612 domicílios (Fundação João Pinheiro, 2013).

Se a área útil mínima considerada for de $39 \mathrm{~m}^{2}$, que é a menor unidade habitacional em apartamento permitida de acordo com o Programa MCMV 5 , a produção poderia ter sido de até 11.497 unidades de HIS, o equivalente a 2,4\% do déficit habitacional urbano no município de São Paulo do ano de 2010.

Esse potencial fica bastante reduzido se a produção resultante da Cota de Solidariedade seguir o padrão da média de lançamentos com preço de venda de até $\mathrm{R} \$ 190$ mil, que é o teto do preço dos empreendimentos do Programa Minha Casa Minha Vida. Adotando o padrão médio dos lançamentos entre 2000 e 2010 com esse preço de venda, que é de $2.983 \mathrm{~m}^{2}$ de terreno por empreendimento, $83 \mathrm{UH}$ por empreendimento e $54 \mathrm{~m}^{2}$ área útil por UH, o potencial de produção é de até 8.303 unidades de HIS, ou o equivalente a $1,8 \%$ do déficit habitacional.

5. De acordo com o item 7.1 do Anexo I da Portaria No 168, de 12 de abril de 2013, disponivel em http://www.cidades.go br/images/stories/ArquivosSNH/ArquivosPDF/Especificacoes/especificacoes_apartamento_port168.pdf, consultado em
13.01.2015. 
Tabela 13 - Potencial de produção de HIS por aplicação da Cota de Solidariedade com base na produção imobiliária entre 2000 e 2010 - Opção 1

\begin{tabular}{|c|c|c|c|}
\hline $\mathbf{m}^{2}$ de área útil & \multicolumn{3}{|c|}{$\mathrm{UH}$} \\
\hline 448.398 & 18.683 & 11.497 & 8.303 \\
\hline - & $\begin{array}{l}4 \% \text { do déficit } \\
\text { habitacional }\end{array}$ & $\begin{array}{c}\text { 2,4\% do déficit } \\
\text { habitacional }\end{array}$ & $\begin{array}{c}1,8 \% \text { do déficit } \\
\text { habitacional }\end{array}$ \\
\hline $\begin{array}{l}10 \% \text { da área útili (proxy da área } \\
\text { computável) de emmpreendimentos com } \\
\text { mais de } 20.000 \mathrm{~m}^{2} \text { de área útil lançados } \\
\text { entre } 2000 \text { e } 2010\end{array}$ & $\begin{array}{l}24 \mathrm{~m}^{2} \text { de área } \\
\text { útil mínima, } \\
\text { conforme Decreto } \\
44.667 / 04\end{array}$ & $\begin{array}{l}39 \mathrm{~m}^{2} \text { de área } \\
\text { util minima, } \\
\text { conforme MCMV }\end{array}$ & $\begin{array}{l}2.983 \mathrm{~m}^{2} \text { de terreno } \\
\text { por empreendimento, } \\
83 \mathrm{UH} \text { por empreendimento } \\
\text { e } 54 \mathrm{~m}^{2} \text { area útil por UH }\end{array}$ \\
\hline
\end{tabular}

Fonte: Lei 6.050/2014, Decreto 44.667/2004, Embraesp/CEM 2000-2010. Elaboraçāo da autora

O Mapa 9 traz o potencial de localização da produção de HIS com base nessa opção de aplicação da Cota de Solidariedade.

Mapa 9 - Potencial de localização da produção de HIS por aplicação da Cota de Solidariedade com base na produção imobiliária entre 2000 e 2010 - Opção 1

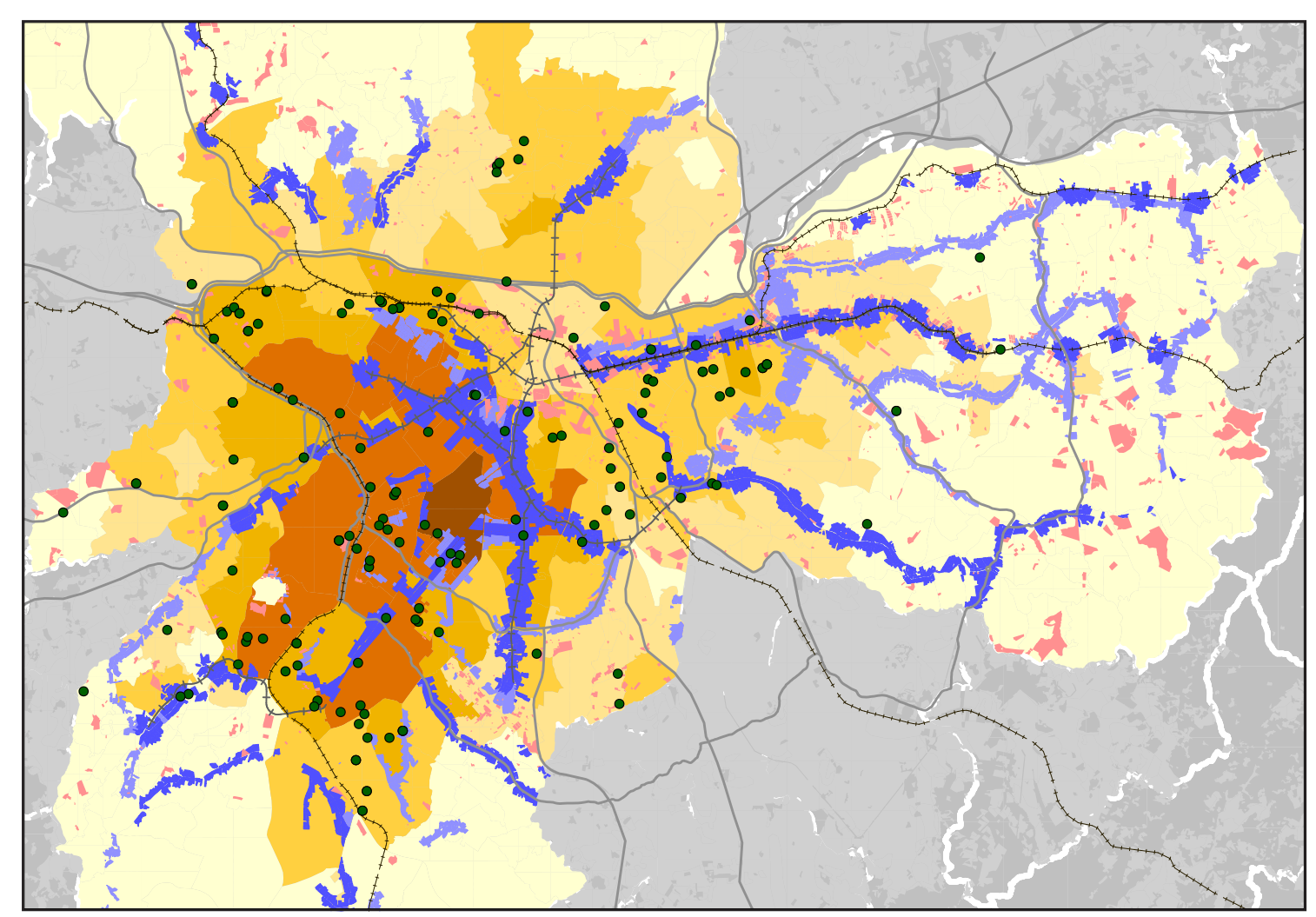

Empreendimentos Verticais (2000-2010) CEM, Centro de Estudos da Metrópole, 201

- Area útili igual ou superior

Eixo Previsto

Renda Média Mensal (R\$)
IBGE 2010 Censo Demográfico

ZEIS 2, 3e 5

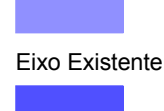

Eixo Existente

$$
\begin{gathered}
\text { Abaixo de } R \$ 680 \\
680 \text { a } 1.000 \\
1.000 \text { a } 2.000
\end{gathered}
$$

1.000 a 2.000

2.000 a 3.000
3.000 a 5.000

Acima de R\$5.000,00
A inovação que a Cota de Solidariedade pode trazer é a mescla de populações de diferentes níveis de renda em localizações muito bem servidas de oferta de empregos e serviços. Essa seria uma chave para a diminuição da segregação social e para a melhoria da mobilidade na cidade.

No entanto, entendemos que há uma possibilidade muito remota de que esta opção seja escolhida por empreendedores. Mesmo com as vantagens concedidas ao empreendedor em relação à ampliação do coeficiente de aproveitamento sem pagamento de outorga onerosa, não há sinais de disposição em compor unidades de HIS com apartamentos de médio ou alto padrão em um mesmo empreendimento, especialmente por não ser essa uma obrigatoriedade, mas uma entre quatro opções dadas ao empreendedor. Em parte, isso acontece pela falta de regulamentação do instrumento. Caso a implantação de HIS se traduzisse em lucro adicional ao empreendedor, talvez mais viável que o próprio empreendedor a elegesse. No entanto, no contexto de um modelo de urbanização segregado, a presença de HIS num empreendimento pode representar inclusive um fator de redução dos preços de venda das unidades 


\section{Opcão 2: Destinação de 10\% da área computável em HIS adicionais em outro local}

Na segunda opção de aplicação da Cota de Solidariedade, a área construída a ser destinada a produção de HIS é a mesma que na primeira opção. A localização é que pode variar muito.

Com base na produção entre 2000 e 2010, seriam destinados a empreendimentos de HIS $448.398 \mathrm{~m}^{2}$ de área útil, o que dependendo de parâmetros dos empreendimentos e das unidades. Considerando o padrão da produção de empreendimentos com valor de venda de até $\mathrm{R} \$ 190.000$, que é de $2.983 \mathrm{~m}^{2}$ de terreno por empreendimento, $83 \mathrm{UH}$ por empreendimento e $54 \mathrm{~m}^{2}$ área útil por $\mathrm{UH}$, poderiam ter sido produzidas até 8.303 unidades de HIS. Se aplicarmos o parâmetro de área útil mínima de $24 \mathrm{~m}^{2}$ por unidade de HIS, estabelecido pelo Decreto /04, teriam sido produzidas 18.683 unidades de HIS. Aplicando a área útil mínima de $39 \mathrm{~m}^{2}$, de acordo com o Programa MCMV, a produção seria de no máximo11.497 unidades de HIS, ou 2,4\% do déficit habitacional urbano no município de São Paulo do ano de 2010.

Os empreendimentos de HIS gerados pela aplicação do instrumento podem localizar-se na Macrozona de Estruturação e Qualificação Urbana, excluída a Macroárea de Redução da Vulnerabilidade Urbana e os Setores Jacu-Pêssego, Arco Leste, Noroeste e Fernão Dias da Macroárea de Estruturação Metropolitana.

Considerando que os empreendimentos aos quais se aplica a Cota de Solidariedade são os que apresentam área computável maior que $20.000 \mathrm{~m}^{2}$, e a produção de HIS deve equivaler a 10\% dessa área, os terrenos aptos a receber essa produção são: i) os maiores que $1.000 \mathrm{~m}^{2}$, que com coeficiente de aproveitamento máximo igual a 2 geram $2.000 \mathrm{~m}^{2}$ de área computável; ou ii) os maiores que $500 \mathrm{~m}^{2}$ localizados nos Eixos de Estruturação da Transformação Urbana, que apresentam coeficiente de aproveitamento máximo igual a 4, e também resultam em empreendimentos maiores que $2000 \mathrm{~m}^{2}$.
No mapa 10, a seguir, visualizamos os lotes vagos maiores que $500 \mathrm{~m}^{2}$ localizados nos Eixos de Estruturação da Transformação Urbana. No total, são 178 lotes vagos localizados na cidade como um todo. Dos 178 terrenos vagos na cidade como um todo, 113 deles localizam-se no Eixos de Estruturação da Transformação Urbana, somando pouco mais de 13 milhões de $\mathrm{m}^{2}$, ou, como referência, aproximadamente 1.316 quadras de $10.000 \mathrm{~m}^{2}$. Se todos os lotes vagos ao longo dos Eixos fossem prioritariamente ocupados, o potencial de produção seria de 52.642.201 $\mathrm{m}^{2}$ de área computável, 117 vezes maior que o potencial de produção pela aplicação da Cota de Solidariedade considerando o período entre 2000 e 2010, que é de $448.398 \mathrm{~m}^{2}$.

Mapa 10 - Potencial de localização da produção de HIS - Opções 2 e 3


Fonte: Embraesp/CEM 2000-2010, PDE 2014. Elaboraçăo de Edson Capitânio e da autora 
No mapa 11 vemos os lotes vagos maiores que $1.000 \mathrm{~m}^{2}$ localizados na Macrozona de Estruturação e Qualificação Urbana, excluída a Macroárea de Redução da Vulnerabilidade Urbana e os Setores Jacu-Pêssego, Arco Leste, Noroeste e Fernão Dias da Macroárea de Estruturação Metropolitana, e excluindo também os Eixos de Estruturação da Transformação Urbana. São 65 terrenos que somam $51.348 .626 \mathrm{~m}^{2}$, ou 513 quadras, o que permitiria uma produção de 102.697.153 m² de área computável de HIS, 229 vezes o potencial de produção de HIS por meio da Cota de Solidariedade considerando o período entre 2000 e 2010.

Mapa 11 - Potencial de localização da produção de HIS - Opções 2 e 3

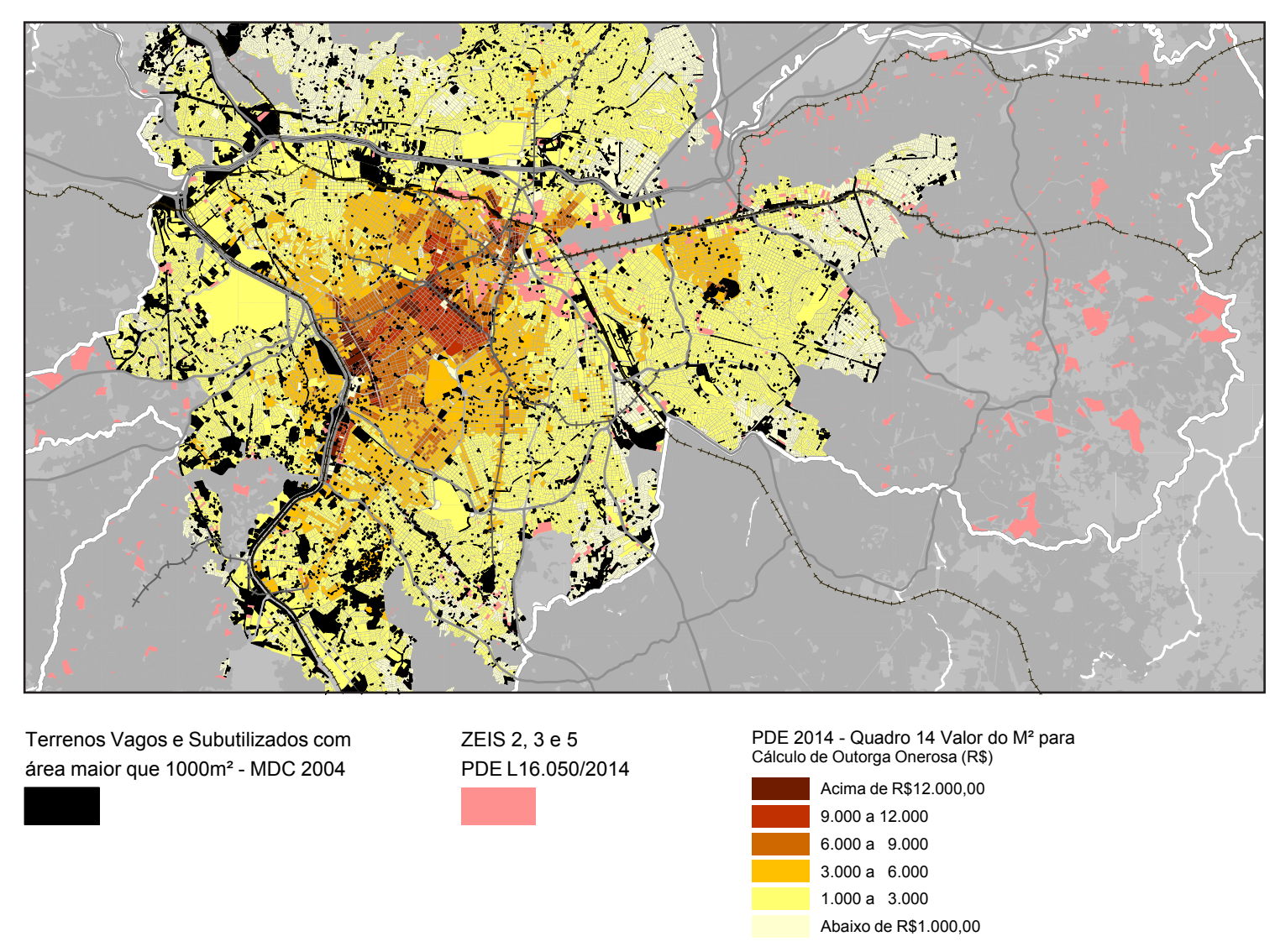

Fonte: Embraesp/CEM 2000-2010, PDE 2014. Elaboraçāo de Edson Capitânio e da autora.
Na Tabela 14 vê-se as possibilidades de aplicação dessa opção:

Tabela 14 - Potencial de produção de HIS por aplicação da Cota de Solidariedade com base na produção imobiliária entre 2000 e 2010 - Opção 2

\begin{tabular}{|c|c|c|c|}
\hline$m^{2}$ de área útil & & UH & \\
\hline 448.398 & 18.683 & 11.497 & 8.303 \\
\hline- & $\begin{array}{l}4 \% \text { do déficit } \\
\text { habitacional }\end{array}$ & $\begin{array}{l}2,4 \% \text { do déficit } \\
\text { habitacional }\end{array}$ & $\begin{array}{l}1,8 \% \text { do déficit } \\
\text { habitacional }\end{array}$ \\
\hline $\begin{array}{l}10 \% \text { da área útil dos } \\
\text { empreendimentos com mais de } \\
20.000 \mathrm{~m}^{2} \text { de área útil lançados } \\
\text { entre } 2000 \text { e } 2010\end{array}$ & $\begin{array}{l}24 \mathrm{~m}^{2} \text { de área útil } \\
\text { mina, oconorme } \\
\text { Decreto } 44.667 / 04\end{array}$ & $\begin{array}{c}39 \mathrm{~m}^{2} \text { de área } \\
\text { cutil minima, } \\
\text { conforme MCMV }\end{array}$ & $\begin{array}{l}2.983 \mathrm{~m}^{2} \text { de terreno por } \\
\text { empreendimento, } 83 \mathrm{UH} \text { por } \\
\text { empreendimento e } 54 \mathrm{~m}^{2} \text { área } \\
\text { útil por } \mathrm{UH}\end{array}$ \\
\hline
\end{tabular}

Fonte: Lei 6.050/2014, Decreto 44.667/2004, Embraesp//EEM 2000-2010. Elaboraçăo da autora

Se a Opção 1 traz um potencial grande de combate à segregação, ao unir diferentes per fis de renda num mesmo empreendimento, preferencialmente em áreas já estruturadas da cidade, o que se vê com as Opções 2 e 3, representada espacialmente nos Mapas 10 e 11, é a reprodução de um padrão de localização que potencialmente levaria as unidades de HIS para as áreas periféricas da cidade, onde de encontram a maioria dos terrenos vagos e subutilizados com área suficiente para receber a produção de HIS nos moldes aqui identificados. 
Opção 3: Doação de terreno com valor equivalente a $10 \%$ do valor do terreno do empreendimento gerador de Cota de Solidariedade

A terceira opção é a que contém o maior potencial de transformação da política habitacional de interesse social. Considerando que a maior dificuldade para a produção de habitação de interesse social é a aquisição de terras, tanto pelos altos valores definidos em processos de desapropriação, como também pelo longo tempo de tramitação e conclusão desses processes, a doação de terrenos para o município atuaria diretamente no gargalo da política habitacional de interesse social.

Definidas as terras de propriedade municipal onde se construirá unidades habitacionais, fica a critério da municipalidade a tipologia a ser utilizada, que pode variar de acordo com a situação de localização, da demanda a ser atendida etc, possibilitando o distanciamento do padrão repetitivo produzido pelo mercado.

A simulação da aplicação dessa alternativa é de difícil cálculo. O terreno a ser doado deve ter valor equivalente a $10 \%$ do valor do terreno a ser licenciado, tomando como referência os valores de metro quadrado de terreno para cálculo da outorga onerosa para os dois terrenos.

Utilizando-nos de um exemplo para esclarecer, se o terreno a ser licenciado tem 10.000 $\mathrm{m}^{2}$ (lembrando que a média de área de terreno dos empreendimentos maiores de 20.000 $\mathrm{m}^{2}$ de área computável lançados entre 2000 e 2010 foi de $13.257 \mathrm{~m}^{2}$ ) e, de acordo com a tabela de referência, custa $\mathrm{R} \$ 5.000,00$ por $\mathrm{m}^{2}$, temos que o valor do terreno a ser licenciado é de $\mathrm{R} \$ 50$ milhões. O valor do terreno a ser doado deve equivaler a $10 \%$ do terreno licenciado, ou, no nosso exemplo, $\mathrm{R} \$ 5$ milhões. $\mathrm{O}$ terreno a ser doado vai resultar de uma combinação entre localização e área. Se for localizado em uma área muito valorizada de acordo com a tabela de referência, cujo valor do metro quadrado seja de $\mathrm{R} \$ 20.000,00$ por $\mathrm{m}^{2}$, a área do terreno doado será de $250 \mathrm{~m}^{2}$. Supondo que esse terreno esteja localizado nos Eixos de Estruturação da Transformação Urbana, cujo coeficiente de aproveitamento construir 41 unidades de HIS em uma localização provavelmente muito boa, em que nos padrões vigentes dificilmente teríamos oferta de HIS. Agora se o terreno a ser doado estiver localizado em uma área onde o metro quadrado vale, pelo quadro de referência, $\mathrm{R} \$ 1.000,00$, esse terreno teria uma área de $5.000 \mathrm{~m}^{2}$, cujo potencial construtivo chega a $20.000 \mathrm{~m}^{2} \mathrm{em}$ caso do terreno estar localizado em Eixo de Estruturação da Transformação Urbana, ou 208 unidades de HIS de $24 \mathrm{~m}^{2}$ de área computável cada uma. Essas possibilidades encontram-se sistematizadas na Tabela 15.

Tomando os cálculos do exemplo acima, uma questão pode ser colocada: para a política habitacional na escala do município, o que é mais efetivo: 41 unidades de HIS em uma localização excelente, onde de acordo com o padrão produtivo vigente não se teria nenhuma oferta desse tipo de habitação, ou 208 unidades de HIS onde o padrão de urbanização já é de predomínio de residencial de interesse social em relação a outros usos? Pequena escala pontualmente, ou maior escala de mais do mesmo?

Abaixo, propomos uma simulação do potencial de área de terrenos a serem doados ao município. Para facilitar essa simulação, consideramos que os terrenos a serem licenciados e os terrenos a serem doados localizam em uma região isonômica de valores por $\mathrm{m}^{2}$ de terreno. A visualização do Mapa 12, a seguir, facilita o entendimento dessa hipótese

Tabela 15 - Potencial de aquisição de terrenos e de produção de HIS por aplicação da Cota de Solidariedade com base na produção imobiliária entre 2000 e 2010 - Opção 3

\begin{tabular}{|c|c|c|c|c|c|c|c|}
\hline \multicolumn{2}{|c|}{$\mathbf{m}^{2}$ de área útil } & \multicolumn{5}{|c|}{ UH } & \multirow{2}{*}{$\begin{array}{c}\mathrm{m}^{2} \text { de terreno } \\
210.798\end{array}$} \\
\hline 843.192 & 421.596 & 35.133 & 17.566 & 21.620 & 10.810 & 5.865 & \\
\hline & & $\begin{array}{l}7,5 \% \text { do } \\
\text { déficit }\end{array}$ & $4 \%$ do déficit & $\begin{array}{l}4,6 \% \text { do } \\
\text { déficit }\end{array}$ & $\begin{array}{l}2,3 \% \text { do } \\
\text { déficit }\end{array}$ & $1,2 \%$ do déficit & \\
\hline $\begin{array}{l}\text { CA=4, nos } \\
\text { Exixos de Es- } \\
\text { truturaçáo da } \\
\text { Transforma- } \\
\text { câurouna }\end{array}$ & $\begin{array}{c}\text { CA=2, fora } \\
\text { dos Exixos de } \\
\text { Estruturaçāao } \\
\text { do Trans- } \\
\text { formacāo } \\
\text { Urbana }\end{array}$ & 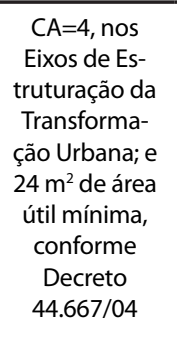 & $\begin{array}{c}\text { CA=2, fora } \\
\text { dos Eixos de } \\
\text { Estruturaçăo } \\
\text { da Trans- } \\
\text { formaçăo } \\
\text { Urbana e } 24 \\
m^{2} \text { de área } \\
\text { útil mínima, } \\
\text { conforme } \\
\text { Decreto } \\
44.667 / 04\end{array}$ & $\begin{array}{c}\text { CA }=4, \text { nos } \\
\text { Eixos de Es- } \\
\text { truturação da } \\
\text { Transforma- } \\
\text { ção Urbana; } \\
39 m^{2} \text { deárea } \\
\text { útil mínima, } \\
\text { conforme } \\
\text { MCMV }\end{array}$ &  & $\begin{array}{c}2.983 \mathrm{~m}^{2} \mathrm{de} \\
\text { terreno por em- } \\
\text { preendimento, } \\
83 \mathrm{UH} / \mathrm{empreen}- \\
\text { dimento e } 5 \mathrm{~m}^{2} \\
\text { área útil/ } / \mathrm{UH}\end{array}$ & $\begin{array}{c}10 \% \text { da área } \\
\text { de terreno dos } \\
\text { empreendimen- } \\
\text { tos com mais } \\
\text { de } 20.000 \mathrm{~m}^{2} \text { de } \\
\text { área útil lançados } \\
\text { entre } 2000 \mathrm{e} \\
2010, \text { conside- } \\
\text { rando isonomia } \\
\text { de valores de } \\
\text { terreno }\end{array}$ \\
\hline
\end{tabular}

Fonte: Lei 6.050/2014, Decreto 44.667/2004, Embraesp//EM 2000-2010. Elaboração da autora 
Mapa 12 - Potencial de localização da produção de HIS - Opção 3

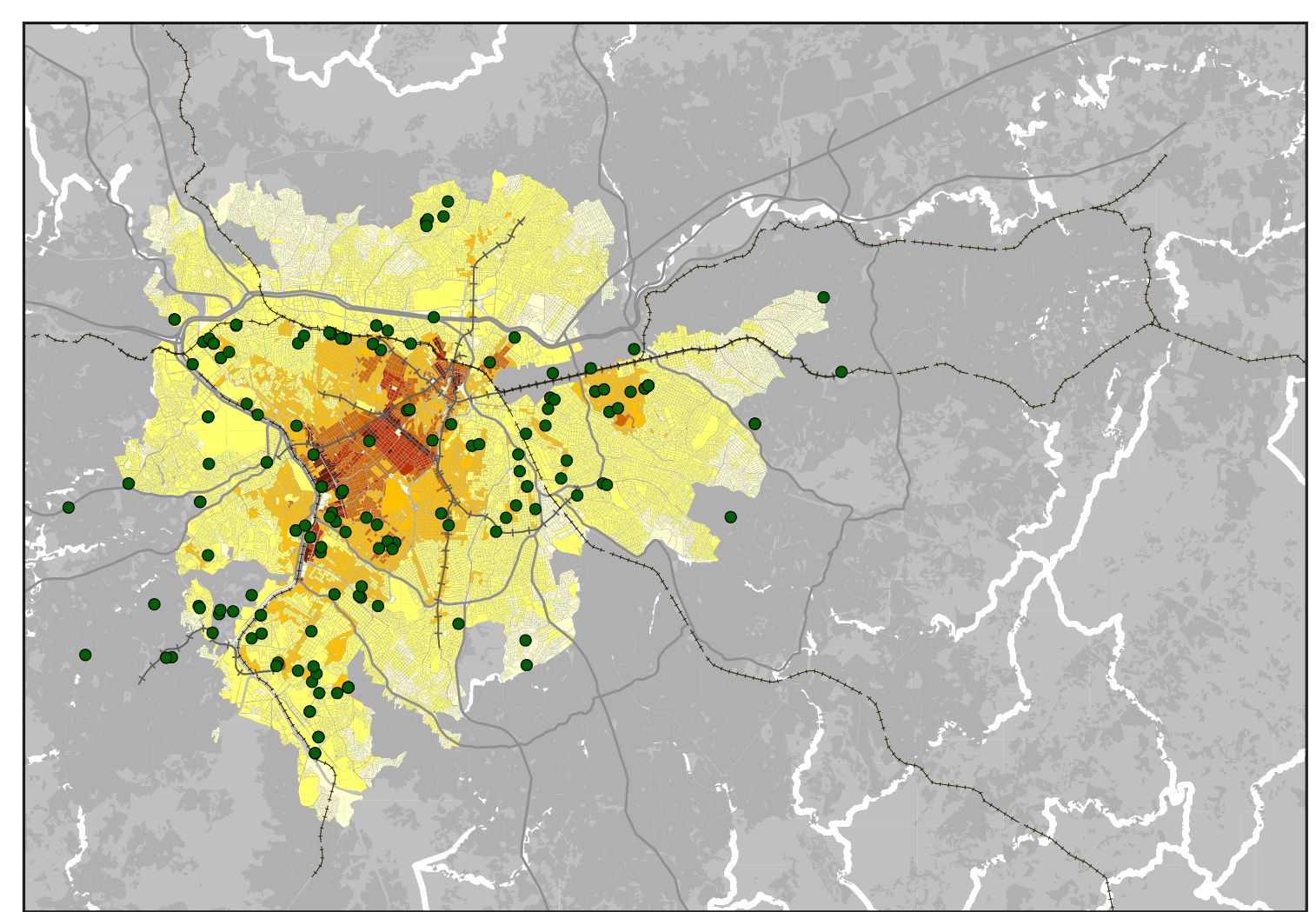

Empreendimentos Residenciais ou não-residenciais, com área útil superior a 20.000m², 2000 a 2010 CEM - Centro de Estudos da Metrópole, 2011

$$
\begin{aligned}
& \text { PDE } 2014 \text { - Quadro } 14 \text { Valor do } M^{2} \text { para } \\
& \text { Cálculo de Outorga Onerosa ( } R \$ \text { ) } \\
& \text { Acima de } R \$ 12.000,00 \\
& 9,000 \text { a } 12,000 \\
& 6,000 \text { a } 9,000 \\
& 3,000 \text { a } 6,000 \\
& 1,000 \text { a } 3,000 \\
& \text { Abaixo de } R \$ 1.000,00
\end{aligned}
$$

Fonte: Embraesp/CEM 2000-2010, PDE 2014. Elaboração da autora e de Edson Capitânio.

A produção de empreendimentos entre 2000 e 2010 com área computável maior que $20.000 \mathrm{~m}^{2}$ consumiu $2.107 .980 \mathrm{~m}^{2}$ de terrenos. Para facilitar a simulação e a análise, consideremos que os terrenos a serem licenciados e os terrenos a serem doados pela aplicação desta opção da Cota de Solidariedade localizam-se em áreas de mesmo valor por $\mathrm{m}^{2}$. Teríamos assim, um potencial de doação de terrenos ao município de $210.798 \mathrm{~m}^{2}$.
O potencial de produção de HIS a partir da utilização desses terrenos pode variar muito de acordo com a tipologia adotada e também com a localização desses terrenos. Se for adotado para a produção de HIS a tipologia dos empreendimentos produzidos pelo mercado privado entre 2000 e 2010 com preço de venda de até $\mathrm{R} \$ 190.000,00^{6}$, que utilizaram em média $2.983 \mathrm{~m}^{2}$ de terreno por empreendimento com 83 unidades habitacionais por empreendimento, e $54 \mathrm{~m}^{2}$ área útil por unidade habitacional, teríamos um potencial de produção de 5.865 unidades habitacionais, que representam apenas 1,8\% do déficit habitacional no município de São Paulo em 2010, de 472.612 unidades. Em caso de adotada a área mínima de unidades de HIS conforme o Decreto n 44.667/2004, que é de $24 \mathrm{~m}^{2}$ de área útil, o potencial de unidades de HIS a serem produzidas é de 35.133 unidades para terrenos localizados nos Eixos de Estruturação da Transformação Urbana, o equivalente a uma redução de 7,5\% do déficit habitacional em dez anos, e de 17.566 unidades, aproximadamente $4 \%$ do déficit habitacional, para terrenos localizados fora dos Eixos.

A localização dos terrenos a serem doados nos Eixos de Estruturação da Transformação Urbana possibilita, além de agilizar com a disponibilização imediata de terrenos a implementação da política pública de habitação de interesse social, permitindo dobrar o potencial de produção de HIS. Essa alternativa de aplicação da Cota de Solidariedade deveria ser incentivada em comparação às outras. 
Opção 4: Doação de valor correspondente a $10 \%$ do valor do terreno objeto do empreendimento gerador de Cota de Solidariedade para o FUNDURB

Na quarta opção de aplicação do Cota de Solidariedade, o empreendedor faz uma doação ao Fundo de Desenvolvimento Urbano - FUNDURB no valor equivalente a 10\% do valor do terreno a ser licenciado ${ }^{7}$, calculado de acordo com o Quadro 14 da Lei 16.050/2014 - PDE, que estabelece valores por $\mathrm{m}^{2}$ de terrenos para fins de cálculo da Outorga Onerosa no município.

O Mapa 13, a seguir, mostra a localização dos empreendimentos com mais de $20 \mathrm{mil} \mathrm{m}^{2}$ de área útil lançados entre 2000 e 2010. Supondo que a Cota de Solidariedade estivesse vigente à época, seriam esses os empreendimentos a que se aplicaria esse instrumento. Mostra também, em manchas, faixas de valor de terreno calculadas por composição das faces de quadras, conforme valores do Quadro 14 da Lei 16.050/2014.

Elaboramos, ainda, um cálculo para simulação do valor que potencialmente seria depositado no FUNDURB caso a Cota de Solidariedade estivesse vigente entre 2000 e 2010, e todos os empreendedores optassem pela alternativa de depósito de $10 \%$ do valor do terreno do Fundo. Para isso, utilizamos a localização dos empreendimentos e a área total dos terrenos em que foram implantados ${ }^{8}$, verificamos o valor por metro quadrado dessa localização no Quadro 14 do PDE, e por meio desse cálculo, obtivemos o valor de cada terreno. Então calculamos o valor total dos 159 terrenos em que foram implantados os empreendimentos com área maior que $20.000 \mathrm{~m}^{2}$ lançados entre 2000 e 2010. O equivalente a $10 \%$ desse total do valor dos terrenos é o montante de recursos que potencialmente seria destinado ao FUNDURB como resultado da aplicação da Cota de Solidariedade, somando R $\$ 636,25$ milhões.

\footnotetext{
7. O cálculo do valor do terreno a ser licenciado e do terreno a ser doado é realizado de acordo com o Quadro 14 da Lei
16.050/2014, que estabelece valores por $\mathrm{m} 2$ de terrenos para cada face de quadra fiscal do município.
} 8. Dados Embraesp/CEM 2000 a 2010.
Mapa 13 - Potencial de localização da produção de HIS - Opção 4

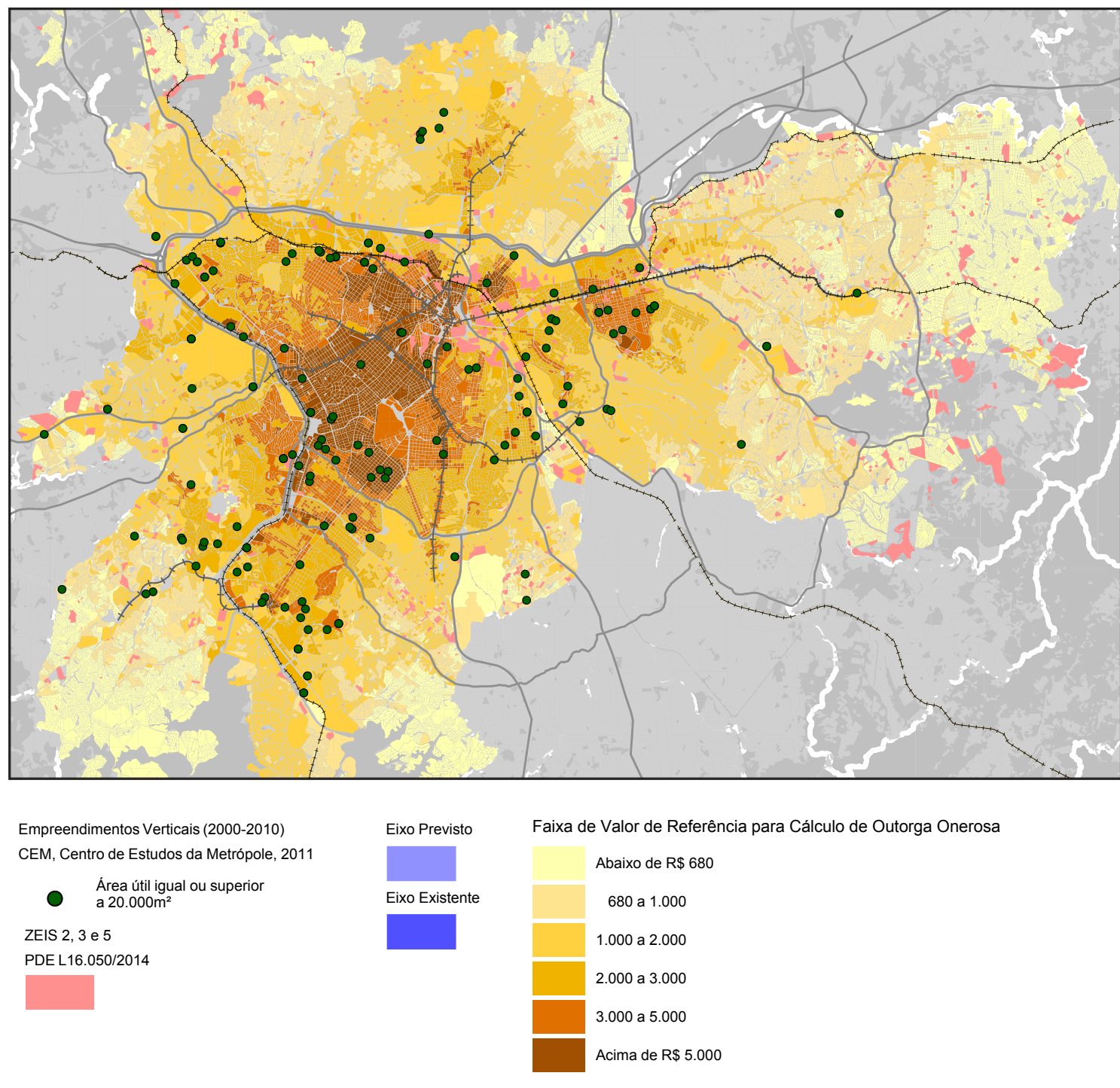

Fonte: Embraesp/CEM 2000-2010, PDE 2014. Elaboraçăo da autora e de Edson Capitânio.

Considerando que esses recursos seriam utilizados para desapropriação de terrenos em localizações com acesso excelente a infraestruturas, serviços e equipamentos, onde se deseja e se necessita que moradias de interesse social sejam implantadas, utilizamos para a simulação do potencial de terrenos a serem adquiridos um valor de $\mathrm{R} \$ 6.000,00$ por metro quadrado de terreno, que é o valor limite para terrenos localizados na área apontada no Mapa 13 em laranja, bastante similar ao limite do centro expandido do município. Esse cálculo indica a capacidade de desapropriar $106.041 \mathrm{~m}^{2}$ de terrenos em boas localizações com recursos advindos da Cota de Solidariedade, ou um pouco mais que a metade da capacidade de aquisição de terrenos por doação direta - opção 3 de aplicação da Cota. 
Caso fossem desapropriados terrenos no limite entre as áreas laranja e amarela escura do mapa - onde se localiza a maioria dos empreendimentos com área útil maior que $20.000 \mathrm{~m}^{2}$ lançados entre 2000 e 2010, com valor estimado de $\mathrm{R} \$ 3.000,00$ por metro quadrado de terreno, a capacidade de desapropriação seria de $212.083 \mathrm{~m}^{2}$ de terrenos, bem próximo à capacidade de aquisição de terrenos por doação direta - opção 3 de aplicação da Cota. Na tabela 16, abaixo, congregamos essas possibilidades:

Tabela 16 - Potencial de aquisição de terrenos e de produção de HIS por aplicação da Cota de Solidariedade com base na produção imobiliária entre 2000 e 2010 - Opção 4

\begin{tabular}{|c|c|c|c|c|c|c|}
\hline \multicolumn{5}{|c|}{ UH } & $\mathrm{m}^{2}$ de terreno & RS \\
\hline 17.673 & 5.438 & 10.876 & 8.836 & 2.950 & 106.041 & 636,25 milhōes \\
\hline $3,7 \%$ do déficit & 1,1\% do déficit & $2,3 \%$ do déficit & $1,9 \%$ do déficit & $0,6 \%$ do déficit & & \\
\hline $\begin{array}{l}\text { CA=4, nos Eixos } \\
\text { de Estruturaçăo } \\
\text { da Transforma- } \\
\text { ção Urbana; e } 24 \\
m^{2} \text { de área útil } \\
\text { mínima, con- } \\
\text { forme Decreto } \\
44.667 / 04\end{array}$ & $\begin{array}{l}C A=2, \text { nos Eixos } \\
\text { de Estruturação } \\
\text { da Transforma- } \\
\text { ção Urbana; } \\
39 m^{2} \text { de área } \\
\text { útil mínima, } \\
\text { conforme } \\
\text { MCMV }\end{array}$ & $\begin{array}{l}\text { CA=4, nos Eixos } \\
\text { de Estruturação } \\
\text { da Transforma- } \\
\text { ção Urbana; e } \\
39 \mathrm{~m}^{2} \text { de área } \\
\text { útil mínima, } \\
\text { conforme } \\
\text { MCMV }\end{array}$ & $\begin{array}{l}\text { CA=2, nos Eixos } \\
\text { de Estruturação } \\
\text { da Transforma- } \\
\text { ção Urbana; e } \\
24 \mathrm{~m}^{2} \text { de área } \\
\text { útil mínima, } \\
\text { conforme De- } \\
\text { creto } 44.667 / 04\end{array}$ & $\begin{array}{l}2.983 \mathrm{~m}^{2} \mathrm{de} \\
\text { terreno por } \\
\text { empreendi- } \\
\text { mento, } 83 \mathrm{UH} / \\
\text { empreendimen- } \\
\text { to e } 54 \mathrm{~m}^{2} \text { área } \\
\text { úti//UH }\end{array}$ & $\begin{array}{c}\mathrm{R} \$ 6.000,00 \\
\text { por metro } \\
\text { quadrado de } \\
\text { terreno a ser } \\
\text { desapropriado }\end{array}$ & $\begin{array}{l}10 \% \text { do valor dos } \\
\text { terrenos dos em- } \\
\text { preendimentos com } \\
\text { mais de } 20.000 \mathrm{~m}^{2} \\
\text { de área útil lançados } \\
\text { entre } 2000 \text { e } 2010 \\
\text {, de acordo com } \\
\text { Quadro } 14 \text { da Lei } \\
16.050 / 2014\end{array}$ \\
\hline
\end{tabular}

Fonte: Lei 6.050/2014. Elaboraçăo da autora.

Embora o potencial numérico das alternativas de doação de terrenos e doação de recursos ao FUNDURB possam ser similares de acordo com as condições de localização dos empreendimentos a serem licenciados e dos terrenos a serem doados, em termos de tempo e custo de implantação de projetos de habitação de interesse social a opção por doação direta de terrenos ao município é bastante vantajosa, pois prescinde a etapa de desapropriação de terrenos, apontada por gestores públicos como o grande gargalo da implementação de políticas públicas.

\subsection{2 - Potencial transformador minimizado}

A abrangência do instrumento Cota de Solidariedade é pequena, aplicável a apenas $2,5 \%$ da produção imobiliária do município no período estudado como referência, de 2000 a 2010, quando a produção imobiliária deu um grande salto. A implementação nos moldes aprovados, com a Cota de Solidariedade sendo aplicada apenas para imóveis que superem a marca de área computável de $20.000 \mathrm{~m}^{2}$ acaba por restringir muito seu potencial. Uma redução de, por exemplo, 50\% na linha de corte de aplicação do instrumento, variando de $20.000 \mathrm{~m}^{2}$ para $10.000 \mathrm{~m}^{2}$ a área computável do empreendimento a ser licenciado, ampliaria a abrangência do instrumento em aproximadamente $460 \%$. Seriam 730 empreendimentos em que a Cota de Solidariedade incidiria, ao invés de 159. Ou ainda, se a aplicação do instrumento abrangesse, por exemplo, faixas progressivas que envolvessem imóveis também menores do que esse parâmetro, a Cota de Solidariedade teria um impacto muito maior.

De acordo com a simulação realizada nesta pesquisa, a aplicação da Cota de Solidariedade poderia ter resultado na aquisição de pouco mais de $210 \mathrm{mil} \mathrm{m} 2$ de terrenos. Ou ainda na produção de por volta de $450 \mathrm{mil} \mathrm{m2}$ de área útil de habitação de interesse social, variando entre aproximadamente 6.000 e 35.000 novas unidades habitacionais, dependendo da tipologia utilizada e da opção entre destinação de unidades de HIS, doação de terrenos ou doação de recursos ao FUNDURB.

O menor potencial de produção de HIS resultaria da implantação da Opção 1, de empreendimentos com mesmo padrão dos empreendimentos residenciais de até $\mathrm{R} \$ 190.000^{10}$ lançados entre 2000 e 2010, que tem em média $2.983 \mathrm{~m}^{2}$ de terreno por empreendimento, 83 unidades e $54 \mathrm{~m}^{2}$ por unidade. A adoção dessa opção equivaleria à produção de 35.133 novas unidades, ou o equivalente a 1,2 do déficit habitacional urbano do

9. De acordo com os dados da Embraesp/CEM e da ABRASCE 2000-2010, foram lançados 669 empreendimentos residencials com àrea útil maior que $10.000 \mathrm{mz}$ entre $2000 \mathrm{e} 2010$. Maiores que $20.000 \mathrm{~m} 2$ foram 138; 45 empreendimentos comercials em lugar de 8; e 16 shoppings, ao invés de 13. Para os shoppings, visto que os dados existentes referem-se a area total con-

10. Preço máximo em 2014 dos empreendimentos inseridos no Programa Minha Casa Minha Vida. 
município de São Paulo em 2010, que era de 471.612 domicílios (FJP, 2013). Como já apontado anteriormente, a lacuna de regulamentação no tocante à destinação e gestão das unidades representa uma complicação adicional. Sem os parâmetros precisos estipulados para viabilizar essa opção, sua atratividade perde ainda mais apelo, especialmente se considerarmos que a própria destinação de unidades para HIS num empreendimento voltado para as faixas de renda médias ou superiores poderia ter um efeito negativo sobre os preços do empreendimento e suas unidades.

O maior potencial de produção de HIS por meio da Cota de Solidariedade resultaria da Opção 3, com a doação de terrenos à municipalidade. Considerando que haveria isonomia de valores por metro quadrado dos terrenos a serem licenciados e dos terrenos doados (conforme Quadro 14 da Lei 16.650/2014), teríamos a aquisição por doação de $210.798 \mathrm{~m} 2$ de novos terrenos municipais. Se localizados nos Eixos de Estruturação da Transformação Urbana, que apresentam coeficiente de aproveitamento igual a 4 sem pagamento de outorga onerosa, esses terrenos admitiriam a construção de $843.192 \mathrm{~m} 2$ de área computável, produzindo 35.133 unidades habitacionais com área útil de $24 \mathrm{~m} 2$, área mínima da unidade residencial de acordo com Decreto 44.667/200411. Essa hipótese representa uma produção do equivalente a 7,5\%. do déficit habitacional do município de São Paulo.

Apesar do potencial transformador das desigualdades sócio-espaciais apresentadas pelas duas alternativas de aplicação do instrumento descritas acima, julgamos que elas tendem a ser preteridas em favor de outras duas opções: a Opção 4, de doação de 10\% do valor do terreno gerador de Cota ao Fundo de Desenvolvimento Urbano - FUNDURB, de aplicação mais simples e rápida para o empreendedor em geral; e Opção 2, com a produção de $10 \%$ da área computável do empreendimento gerador de Cota em HIS em outra localidade, que pode bastante ser interessante para grupos de empresas imobiliárias que atuam simultaneamente em setores residenciais de alta e de baixa rendas.
No caso da escolha por pagamento direto ao FUNDURB (Opção 4), pode parecer que seria aberta uma a possibilidade, a partir do aumento no volume de recursos, para a construção de empreendimentos de HIS em localizações estruturadas. Isso, no entanto, tende a permanecer apenas como potencial. $\mathrm{O}$ acréscimo de recursos ao fundo não libertaria sua gestão dos mesmos problemas mercadológicos de que é refém. Terrenos em localizações estruturadas são mais caros, sendo possível produzir um número muito maior de unidades num lugar onde a terra é mais barata do que em localizações que realmente permitam o enfrentamento do problema da segregação. Seguimos com os obstáculos ao equacionamento do problema habitacional concentrados na questão da terra, tanto nas formas de aquisição como na própria estrutura fundiária.

Ao abrir as diversas possibilidades apresentadas neste estudo, com a grande variação no potencial de construção de unidades de HIS e de enfrentamento da segregação espacial o instrumento urbanístico acaba tendo sua eficácia tolhida. A sua aplicação joga contra o seu próprio objetivo, atuando de forma difusa e ambígua, aproximando-se menos da resolução de um problema grave e real que de um instrumento protocolar.

A inclusão da Cota de Solidariedade dentre os instrumentos urbanísticos com objetivo de ampliação da produção de HIS e da diminuição da segregação sócio-espacial pode ser considerada um avanço, mas no formato como o instrumento foi aprovado no Plano Diretor Estratégico, não é capaz de mobilizar recursos e esforços suficientes para um enfrentamento de nenhum dos dois objetivos acima colocados.

Isso porque é um instrumento subordinado aos padrões de produção e de localização imobiliárias já consagrados, que produzem e reproduzem, de forma associada, a escassez de moradias populares. A condição estipulada para ampliar a produção de HIS é o aumento da produção convencional de empreendimentos com área computável superior a $20.000 \mathrm{~m} 2$. Ou seja, trata-se de uma tentativa de solucionar o problema da segregação, da desigualdade e da falta de HIS por meio da reprodução de padrões urbanos excludentes e segregadores, voltados à parcela do mercado que menos precisa, mas a que mais interessa. 
Concluímos este capítulo com mais um exercício matemático: se mantidas as condições de geração de Cota de Solidariedade identificadas entre 2000 e 2010, quanto tempo levaria para que fosse zerado o déficit habitacional se ele permanecesse no patamar em que se encontra hoje? Se entre 2000 e 2010 o potencial máximo de abatimento do déficit habitacional de São Paulo a partir da construção de HIS através do instrumento analisado teria sido de 7,5\%, para completarmos 100\% seriam necessários mais 13,3 períodos como esse, ou seja, mais 133 anos, no ano de 2147. 
CONSIDERAÇÕES FINAIS

O potencial transformador da Cota de Solidariedade minimizado à conveniência do capital imobiliário 
A reversão da situação de segregação socioterritorial nas cidades brasileiras está diretamente condicionada à transformação da estrutura fundiária atual. Sem o enfrentamento dos obstáculos ao acesso à terra, o crescimento da produção residencial continua seguindo padrões de localização em que ricos e pobres são mantidos apartados.

O Brasil viveu um salto na produção imobiliária a partir dos anos de 2000 que ampliou o estoque habitacional, inclusive de interesse social e de mercado popular, especialmente após o início da operação do Programa Minha Casa Minha Vida, em 2009. No município de São Paulo houve incremento de $20 \%$ do total de domićlios particulares permanentes entre 2000 e 2010 (IBGE 2000, 2010).

Amparado por uma reestruturação nos sistemas de financiamento e crédito para a produção habitacional que fez crescer em aproximadamente 65 vezes o volume financiado com recursos da caderneta de poupança entre 2002 e 2013 (ABECIP, 2014), o boom imobiliário não foi acompanhado de uma reestruturação no sistema fundiário. Com a manutenção do acesso à terra restrito a uma pequena parcela da população, o rápido e vultuoso crescimento da produção imobiliária acirrou as disputas por terrenos, elevando os preços e destinando aos mais pobres as piores localizações. Quais são as respostas do planejamento territorial municipal a esse agravamento da segregação socioterritorial?

Durante o desenvolvimento da tese, buscamos verificar a hipótese de que o enfrentamento das dificuldades do acesso à terra para a produção de habitação de interesse social se dá por meio de instrumentos urbanísticos que são, durante seu processo de formulação ou aplicação, apropriados pelo capital imobiliário e moldados à sua conveniência. Para isso, analisamos um instrumento potencialmente inovador incluído no Plano Diretor Estratégico do município de São Paulo de 2014, a Cota de Solidariedade, e elaboramos simulações da quantidade e de localizações de habitações de interesse social que poderiam resultar de sua aplicação.

A Cota de Solidariedade vincula o licenciamento de grandes empreendimentos à produção de unidades de habitação de interesse social. O Projeto de Lei inicialmente proposto pelo município previa a doação de terrenos pelo empreendedor ao município para fins de produção de HIS, incidindo diretamente no cerne da questão habitacional. Com a inserção, durante o processo legislativo do Plano Diretor, de três novas alternativas para a aplicação da Cota de Solidariedade, a potencial efetividade do instrumento foi minimizada

As simulações do potencial numérico e locacional das quatro opções de aplicação do instrumento foram realizadas com base na produção imobiliária entre 2000 e 2010, e estão apresentadas em detalhes no Capítulo 4 desta tese. A análise mostra que a abrangência da Cota de Solidariedade é muito pequena, incidindo em apenas 2,5\% do total da produção imobiliária do período estudado.

Além disso, as alternativas previstas têm resultados muito díspares entre elas, tanto no número como na localização de unidades que poderiam ser produzidas.

A opção com maior alcance de ampliação do acesso à terra para populações de menores rendimentos resultaria na produção, em dez anos, de aproximadamente 35 mil unidades residenciais de interesse social localizadas junto a eixos de transporte público de média e alta capacidade. Esse número representa uma redução de 7,5\% do déficit habitacional do município em localizações que refletiriam num efetivo avanço em favor da reversão da segregação socioterritorial. No entanto, é a opção menos provável de ser implementada, considerando que as outras alternativas são muito mais vantajosas em termos de custo e tempo para o empreendedor, que é quem decide pela alternativa a ser adotada.

Uma outra opção, que em princípio pode parecer muito boa para o cumprimento dos objetivos da política habitacional municipal, quando analisada com atenção, não se revela positiva. Trata-se da doação pelo empreendedor de recursos financeiros diretamente ao Fundo de Desenvolvimento Urbano - FUNDURB. Os cálculos elaborados no Capítulo 4 revelam um possível incremento nos recursos do FUNDURB pela aplicação da Cota de Solidariedade de pouco mais de $\mathrm{R} \$ 630$ milhões, o que poderia resultar, dependendo da tipologia utilizada, na produção de menos de 3 mil unidades habitacionais em dez anos, numa redução de apenas $0,6 \%$ do déficit habitacional atual. 
A utilização dos recursos do FUNDURB é sujeita à aprovação por seu Conselho Gestor de projetos propostos pelas diferentes Secretarias do poder executivo municipal. Isso implica que a produção de HIS utilizando recursos do Fundo, supondo que o padrão de empreendimentos adotado pela COHAB - SP seja seguido, contariam com as seguintes etapas de produção: i) elaboração e apresentação de proposta de projeto pela Secretaria de Habitação - SEHAB ao FUNDURB; ii) aprovação pelo FUNDURB do projeto proposto pela SEHAB; iii) abertura de processo de aquisição de terreno por meio de desapropriação, ou destinação de terreno público para implantação do projeto; iv) contratação de empresa construtora do conjunto habitacional e acompanhamento do contrato até a entrega; v) entrega das unidades à demanda pré-estabelecida.

Em comparação com as outras opções de aplicação do instrumento, essa é a que resultaria em menor número de unidades habitacionais a serem produzidas, e em maior tempo de implantação. Maior tempo de implantação porque coloca nas mãos do poder público a responsabilidade pela aquisição do terreno, etapa que em outras opções de aplicação do instrumento estariam superadas. Isso traz uma desvantagem inicial que, somada ao prazo necessário à desapropriação de terrenos, ou à localização desprivilegiada do estoque de terras municipais, muito facilmente resultaria na reprodução dos padrões de produção habitacional pública atuais.

Demonstra essa afirmação o fato de Cidade Tiradentes, no extremo leste do município, ter sido o distrito que mais recebeu novos empreendimentos da Faixa 1 do Programa Minha Casa Minha Vida. Em 2010, o distrito contava com pouco mais de 60 mil domicílios (IBGE, 2010), dentre os quais aproximadamente 40 mil unidades habitacionais em conjuntos públi$\cos ^{1}$, quase $70 \%$ do total de domicílios. Entre 2009 e 2012, foram contratados pelo PMCMV onze conjuntos no distrito de Cidade Tiradentes, com um total de 1.882 novas unidades habitacionais ${ }^{2}$, num incremento de aproximadamente $5 \%$ do total de domicílios no distrito, todas elas localizadas em terrenos de propriedade da COHAB - SP remanescentes dos grandes conjuntos implantados a partir da década de 1980.

1. Estimativa realizada com base em dados da COHAB-SP por conjunto e entrevistas. Ver em USINA (2003).

2. De acordo com estudo do LabCidade (2014) a partir de dados da Caixa Econômica Federal, 2012.
Sob as condições atuais de estrutura fundiária, é muito mais ágil a produção de habitação de interesse social pelo poder público onde o município já é proprietário de terras, ou seja, junto a grandes conjuntos habitacionais, áreas de grande concentração de usos residenciais em relação à infraestrutura, equipamentos e serviços existentes. Nessas áreas, o ideal seria não aumentar a densidade residencial, mas sim implantar usos diversificados que proporcionassem a ampliação da oferta de empregos e a dinamização do cotidiano local. Por outro lado, o potencial de reversão da segregação espacial está justamente no aumento da densidade habitacional de populações de rendimentos mais baixos em áreas onde há amplo acesso a infraestruturas, equipamentos e serviços urbanos. Nessas localizações não há terras públicas disponíveis, e a aquisição de terras passa por processos de desapropriação longos e custosos. O enfrentamento dos entraves à aquisição de terras bem localizadas para a produção habitacional de interesse social é um caminho que precisa ser traçado no sentido da reversão da segregação socioterritiorial.

Em síntese, a Cota de Solidariedade é um instrumento urbanístico que apresenta potencial de intervenção na estrutura fundiária no sentido da ampliação do acesso a terras bem localizadas para produção de habitação de interesse social, especialmente se destinadas unidades habitacionais no mesmo local do empreendimento a ser licenciado, ou se doado terreno em localização junto a eixos de transporte de massa, garantindo o amplo acesso a redes consolidadas de infraestrutura, equipamentos e serviços públicos. No entanto, esse potencial fica minimizado com a inserção de alternativas de aplicação do instrumento que permitem a manutenção do padrão de localização periférica de habitações populares. Os interesses do capital imobiliário, em conflito com os interesses no sentido da reversão de desigualdades socioterritoriais, foram acomodados durante o processo legislativo de aprovação do Plano Diretor por meio da adequação do cumprimento de uma obrigação do empreendedor imobiliário à sua conveniência.

Uma reestruturação do sistema fundiário que trate de aspectos registrais da propriedade assim como de regras de parcelamento, edificação e ocupação de imóveis bem localizados é fundamental para o romper com padrões de segregação socioterritorial e avançar para um novo patamar de desenvolvimento, espacialmente mais igualitário, das cidades brasileiras. 
ARANTES, Pedro; FIX, Mariana (2009). "Como o governo Lula pretende resolver o problema da habitação”. Correio da cidadania. Versão original em mimeo. São Paulo: Sociedade para o progresso da Comunicação Democrática.

BALBIM, Renato; KRAUSE, Cleandro; LIMA NETO, Vicente (2013). Minha Casa Minha Vida, Nosso Crescimento: Onde fica a Política Habitacional? XV Encontro da Associação Nacional de Pós-Graduação e Pesquisa em Planejamento Urbano e Regional, 2013.

BALDEZ, Miguel (1989). Sobre o papel do Direito na sociedade capitalista - ocupações coletivas: direito insurgente. Petrópolis: Centro de Defesa dos Direitos Humanos.

BALL, Michael. O desenvolvimento do capitalismo na provisão de habitação. Rev. Espaço \& Debates, São Paulo, n. 36, p. 11-34, 1992.

BARAVELLI, José Eduardo (2014). Trabalho e tecnologia no Programa MCMV. Tese de doutorado. São Paulo: FAU/USP.

BATTAGLIA, Luísa (1995). Cadastros e registros fundiários: a institucionalização do descontrole sobre o espaço no Brasil. Tese de doutorado. São Paulo: FAU/USP.

BOLAFFI, Gabriel (1982). Habitação e urbanismo: o problema e o falso problema. In: MARICATO, Ermínia (Org). A produção capitalista da casa (e da cidade) no Brasil industrial. São Paulo: Alfa-Omega.

BOLAFFI, Gabriel (1981). Para uma nova política habitacional e urbana: possibilidades econômicas, alternativas operacionais e limites políticos. In: VALLADARES, Licia do Prado (Org.). Habitação em questão. 2. ed. Rio de Janeiro: Zahar.

BONDUKI, Nabil (1988). Crise na habitação e a luta pela moradia no pós-guerra. In: KOWARICK, Lucio (Org.) As lutas sociais e a cidade. Rio de Janeiro: Paz e Terra.

BONDUKI, N. Do Projeto Moradia ao Programa Minha Casa Minha Vida. Teoria e Debate, v. 8, p. 8-14, maio-junho 2009.

BURNETT, Carlos Frederico Lago (2009). Da tragédia urbana à farsa do urbanismo reformista: A Fetichização dos Planos Diretores Participativos. Tese de doutorado. São Luís: Universidade Federal do Maranhão.

CARDOSO, Adauto (org.) (2013). O Programa Minha Casa Minha Vida e seus efeitos territoriais. Rio de Janeiro: Letra Capital.
CASTELLS, Manuel (2000). A questão urbana. Rio de Janeiro: Paz e Terra.

CASTELLS, Manuel (1980). Cidade, democracia e socialismo. Rio de Janeiro: Paz e Terra.

COSTA NETO, Joaquim (2006). A questão fundiária nos Parques e Estações Ecológicas do Estado de São Paulo: origens e efeitos da indisciplina da documentação e do registro imobiliário. Tese de doutorado. São Paulo: FAU/USP.

DAVIS, Mike (2006). Planeta favela. São Paulo: Boitempo.

DISPUTAS judiciais por desapropriações crescem e emperram obras do PAC. São Paulo: O Estado de São Paulo, 23 de julho de 2012, p. B1.

FAORO, Raymundo (2008). Os donos do poder. São Paulo: Globo.

FERREIRA, João Sette Whitaket (coord.) (2012). Produzir casas ou construir cidades? Desafios para um novo Brasil urbano. São Paulo: FUPAM.

FIX, Mariana (2011). Financeirização e transformações recentes no circuito imobiliário brasileiro. Tese de doutorado. Campinas: IE/Unicamp.

FIX, Mariana; PEREIRA, Álvaro (2013). "A metrópole brasileira nas políticas setoriais". In: FURTADO, Bernardo; KRAUSE, Cleandro; FRANÇA, Karla. Território metropolitano, políticas municipais. Brasília: IPEA.

FUNDAÇÃO JOÃO PINHEIRO (2013). Déficit habitacional municipal no Brasil. Belo Horizonte: Centro de Estatística e Informações.

GOTTDIENER, Mark (1993). A produção social do espaço urbano. São Paulo: EDUSP.

GRANDES obras são as mais afetadas por ações. São Paulo: O Estado de São Paulo, 23 de julho de 2012, p. B3.

HARVEY, David (1989). The Urban Experience. Baltimore: Johns Hopkins University Press.

HARVEY, David (1994). Flexible Accumulation through Urbanization. In: AMIN, Aish, Post Fordism: a reader. Oxford: Blackwell.

HARVEY, David (2005). A produção capitalista do espaço. São Paulo: Annablume.

HARVEY, David (2006). Limits to Capital. New York: Verso. 
HARVEY, David (2014). Cidades rebeldes: do direito à cidade à revolução urbana. São Paulo: Martins Fontes

HOLANDA, Sérgio Buarque de (1995). Raízes do Brasil. São Paulo: Companhia das Letras. KOWARICK, Lúcio (1993). A espoliação urbana. 2. ed. Rio de Janeiro: Paz e Terra

KRAUSE, Cleandro; BALBIM, Renato; LIMA NETO, Vicente (2013). Minha Casa Minha Vida, Nosso Crescimento: Onde fica a Politica Habitacional? Texto para discussão 1853. Brasília; Rio de Janeiro: IPEA.

LABCIDADE FAUUSP (2014). "Ferramentas para avaliação da inserção urbana dos empreendimentos do MCMV”. São Paulo, FAUUSP.

LEFEBVRE, Henri (1999). A cidade do capital. Rio de Janeiro: DP\&A.

LOGAN, John; MOLOTCH, Harvey (2007). Urban Fortunes: the political economy of place. Berkeley: University of California Press.

MARICATO, Ermínia (org.) (1988). A produção capitalista da casa (e da cidade) no Brasil industrial. São Paulo: Alfa-Ômega.

MARICATO (coord.) (2001). Preço de desapropriação de terras: limites às políticas públicas nas áreas de habitação, meio-ambiente e vias públicas em São Paulo. Relatório de pesquisa realizada pelo Laboratório de Habitação e Assentamentos Humanos da Faculdade de Arquitetura e Urbanismo da Universidade de São Paulo - LabHab/FAUUSP com apoio do Lincoln Institute of Land Policy.

MARICATO, Ermínia (2003). "Metrópole, legislação e desigualdade". In: Estudos Avançados, V.17, $\mathrm{n}^{\circ} 48$

MARICATO, Ermínia (2009a). "Por um novo enfoque teórico na pesquisa sobre habitação”. Cadernos Metrópole, n 21. Rio de Janeiro: Observatório das metrópoles.

MARICATO, Ermínia (2009b). “O 'Minha Casa’ é um avanço, mas a segregação urbana fica intocada”. Carta Maior, edição de 27 de maio. São Paulo: Carta Maior Publicações.

MARICATO, Ermínia (2011). O impasse da política urbana no Brasil. São Paulo: Vozes.

MARQUES, Eduardo; TORRES, Haroldo (orgs.) (2005). São Paulo: segregação, pobreza e desigualdade. São Paulo: Senac.
MARQUES, Eduardo; RODRIGUES, Leandro (2013). "O Programa Minha Casa Minha Vida na metrópole paulistana: atendimento habitacional e padrões de segregação". In: Revista Brasileira de Estudos Urbanos e Regionais, V.15, nº 2

MARTINS, José de Souza (1994). O poder do atraso. São Paulo: Hucitec.

MARTINS, José de Souza (2004). O cativeiro da terra. São Paulo: Hucitec.

MARX, Murillo (1991). Cidade no Brasil: terra de quem? São Paulo: Edusp/Nobel.

MAUTNER, Yvonne (1991). The periphery as a frontier for the expansion of the capital. Tese de doutorado. Londres: Bartlett School of Architecture and Planning, UCL.

MCIDADES - Ministério das Cidades (2009). Plano Nacional de Habitação - Planhab. Brasília: MCidades.

MCIDADES - Ministério das Cidades (2013). Cartilha Minha Casa Minha Vida. Brasília: MCidades.

OLIVEIRA, Francisco (2003). Crítica à razão dualista. São Paulo: Boitempo

PETRELLA, Guilherme (2012). Das fronteiras do conjunto ao conjunto das fronteiras: experiências comparadas de conjuntos habitacionais na região metropolitana de São Paulo São Paulo: Annablume.

RIBEIRO, Luis Cesar de Queiroz; PECHMAN, Robert Moses (1985). O que é questão de moradia. São Paulo: Nova Cultural: Brasiliense.

RIBEIRO, Luis Cesar de Queiroz (1997). Reforma urbana na cidade da crise: balanço teórico e desafios. In: RIBEIRO, Luis Cesar Queiroz; SANTOS JR., Orlando Alves dos (org.). Globalização, fragmentação e reforma urbana: o futuro das cidades brasileiras na crise. Rio de Janeiro: Civilização Brasileira.

ROLNIK, Raquel (2003). A cidade e a lei: legislação, política urbana e territórios na cidade de São Paulo. São Paulo: Nobel/ Fapesp.

ROLNIK, Raquel (org.); BISCHOF, Raphael; KLINTOWITZ, Danielle; REIS, Joyce (2010). Como produzir moradia bem localizada com recursos do programa minha casa minha vida. Brasília: Ministério das Cidades. 
ROYER, Luciana (2014). Financeirização da política habitacional: limites e perspectivas. São Paulo: Annablume.

SAMPAIO, Maria Ruth do Amaral (1994). "O papel da iniciativa privada na formação da periferia paulistana”. Espaço e Debates: $\mathrm{n}^{\circ}$ 37. São Paulo: Neru.

SANTO AMORE, Caio (2013). Entre o nó e o fato consumado. Tese de doutorado. São Paulo: FAU/USP.

SHIMBO, Lucia (2010). Habitação social, habitação de mercado. Tese de doutorado. São Carlos: EESC/USP.

SÍGOLO, Letícia (2014). O boom imobiliário na metrópole paulistana. Tese de doutorado. São Paulo: FAU/USP

SILVA, Helena Menna Barreto (1997). Terra e moradia: que papel para o município? Tese de doutorado. São Paulo, FAUUSP.

SILVA SPINAZZOLA, Patricia Cezario (2008). Impactos da regularização fundiária no espaço urbano. Dissertação de mestrado. São Paulo: FAUUSP.

USINA CENTRO DE TRABALHOS PARA O AMBIENTE HABITADO (vários autores) (2003). Cidade Tiradentes. Plano de Ação Habitacional e Urbano. Programa Bairro Legal. São Paulo: Secretaria de Habitação e Desenvolvimento Urbano da Prefeitura do Município de São Paulo, Cities Alliance.

VAINER, Carlos (2000). Pátria, empresa e mercadoria, notas sobre a estratégia discursiva do planejamento urbano estratégico. In: ARANTES, Otília; VAINER, Carlos; MARICATO, Ermínia. A cidade do pensamento único, desmanchando consensos. Petrópolis: Vozes, p.75-103.

VILLAÇA, Flavio (2001). Espaço intra-urbano no Brasil. São Paulo: Studio Nobel.

VILLAÇA, Flávio (2004). Uma contribuição para a história do planejamento urbano no Brasil. In: DEAK, Csaba; SCHIFFER, Sueli Ramos. O processo de urbanização no Brasil. São Paulo: EDUSP.

VILLAÇA, Flavio (2011). Reflexões sobre as cidades brasileiras. São Paulo: Studio Nobel. 
